\title{
Comparison of Solar Pond Concepts for Electrical Power Generation
}

October 1975

Prepared for the U.S. Energy

Research and Development Administration under Contract E(45-1): 1830 


\section{DISCLAIMER}

This report was prepared as an account of work sponsored by an agency of the United States Government. Neither the United States Government nor any agency Thereof, nor any of their employees, makes any warranty, express or implied, or assumes any legal liability or responsibility for the accuracy, completeness, or usefulness of any information, apparatus, product, or process disclosed, or represents that its use would not infringe privately owned rights. Reference herein to any specific commercial product, process, or service by trade name, trademark, manufacturer, or otherwise does not necessarily constitute or imply its endorsement, recommendation, or favoring by the United States Government or any agency thereof. The views and opinions of authors expressed herein do not necessarily state or reflect those of the United States Government or any agency thereof. 


\section{DISCLAIMER}

Portions of this document may be illegible in electronic image products. Images are produced from the best available original document. 

COMPARISON OF SOLAR POND CONCEPTS

FOR ELECTRICAL POWER GENERATION

\author{
by \\ K. Orumheller \\ J. B. Duffy \\ 0.K. Harling \\ C. A. Knutsen \\ M. A. McKinnon \\ P. L. Peterson \\ L. H. Shaffer (Consultant) \\ D. L. Styris \\ R. Zaworski (Consultant)
}

October 1975

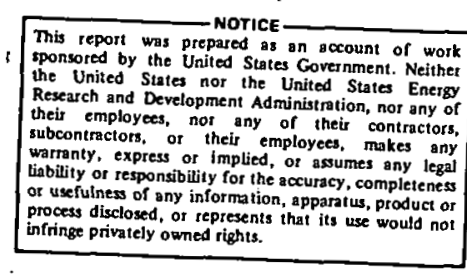

Battelle

-

Pacific Northwest Laboratories

Richland, Washington 99352 
THIS PAGE

WAS INTENTIONALLY

LEFT BLANK 


\section{CONTENTS}

1.0 INTRODUCTION

2.0 SUMMARY

3.0 SOLAR POND TECHNOLOGY

3.1 Nonconvecting Salt Water Pond

3.1 .1 Description : . . •

3.1 .2 Operation .

3.2 Nonconvecting Membrane Pond . . . . . . . . . 3.17

3.2.1 Description '. . . . . . . . . . . 3.17

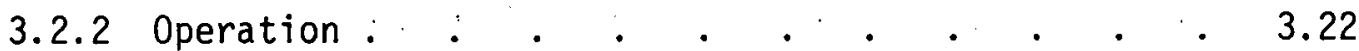

3.3 Viscosity Stabilized Pond . . . . . . . . . . 3.23

3.3.1 Thickeners for Viscosity Stabilized Solar . . . 3.24

3.3.2 Suitability of Various Polymers for Prolonged . . 3.26

3.3.3 Stabilization/Additives $. \quad . \quad . \quad . \quad . \quad . \quad . \quad 3.27$

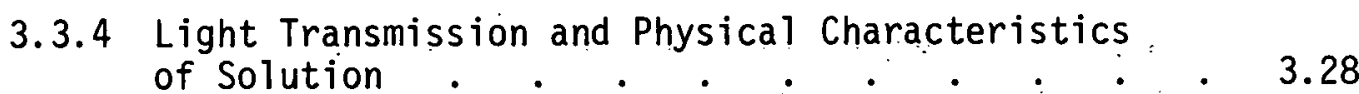

4.0 PRELIMINARY DESIGN . . . .

4.1 Prel iminary Design of Ponds . . . . . . . . . . 4.3

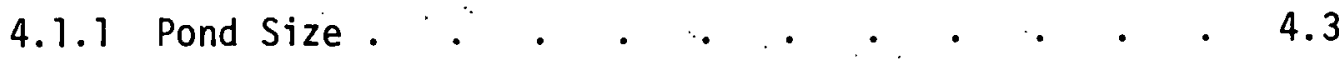

4.1.2 Common Pond Characteristics . . . . . . 4.4

4.1.3 Nonconvecting Salt Pond $:$. . . . . . . 4.11

4.1.4 Nonconvecting Membrane Pond . . . . . . 4.14

4.1.5 Nonconvecting Gelled Pond . . . . . . . 4.17

4.1.6 Shallow Convecting Pond . . . . . . . . . 4.19

4.2 Power Plant . . . . . . . . . . . . . 4.19

4.2.1 Binary Fluid Cycle . . . . . . . . . . 4.24

4.2.2 Flash Steam Cycle. . . . . . . . . . 4.38

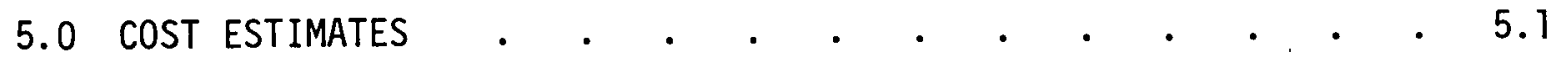

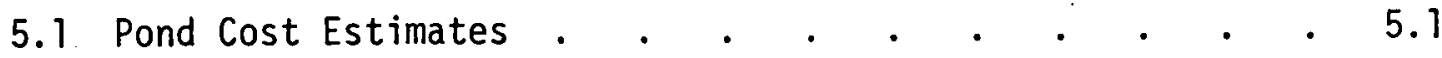

5.1.1 Nonconvecting Pond Cost Estimates . . . $\quad . \quad . \quad 5.1$ 


\section{TABLES}

2.1 Ten Megawatt Electrical Solar Pond Concepts Economic

Summary

5.1 Capital Cost Estimates, $10 \mathrm{MW}$ Nonconvecting

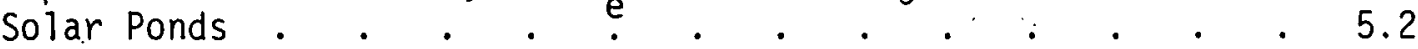

5.2 Capital Cost Estimate for Shallow Solar Pond . . . . . . 5.4

$5.310 \mathrm{MW}$ Solar Pond Concepts - Economic Summary . . . . 5.9

$5.410 \mathrm{MW}$ Sol.ar Pond Concepts - Thermodynamic Summary . . 5.10

5.5 Comparative Evaluation of Solar Pond Concepts: Nonconvecting Salt @ $90^{\circ} \mathrm{C}$ - Binary Cycle . . . . . . 5.18

5.6 Comparative Evaluation of Solar Pond Concepts:
Nonconvecting Salt $080^{\circ} \mathrm{C}$ - Binary Cycle . . . . . . . 5.19

5.7 Comparative Evaluation of Solar Pond Concepts:
Nonconvecting Salt $070^{\circ} \mathrm{C}$ - Binary Cycle . . . . . . 5.20

5.8 Comparative Evaluation of Solar Pond Concepts:
Nonconvecting Salt o $90^{\circ} \mathrm{C}$ - Flashed steam Cycle . . . . . $\quad 5.21$

5.9 Comparative Evaluation of Solar Pond Concepts:
Nonconvecting Salt o $80^{\circ} \mathrm{C}$ - Flashed Steam Cycle . . . . $\quad$. 5.22

5.10 Comparative Evaluation of Solar Pond Concepts $\quad . \quad 5.23$

5.11 Comparative Evaluation of Solar Pond Concepts: Gel o $90^{\circ} \mathrm{C}$ - Binary Cycle . . . . . . . . . 5.24

5.12 Comparative Evaluation of Solar Pond Concepts:
Shallow Pond o $90^{\circ} \mathrm{C}$ - Binary Cycle . . . . . . . . . $\quad 5.25$

5.13 Comparative Evaluation of Solar Pond Concepts:
Nonconvecting Salt (Free Salt) $990^{\circ} \mathrm{C}-$ Binary Cycle. . . . . . . . . . . . . 5.26

5.14 Comparative Evaluation of Solar Pond Concepts: Geothermal Reference Plant o $177^{\circ} \mathrm{C}$ Binary Cycle . . . . . . . . . . . . . 5.27

5.15 Comparative Evaluation of Solar Pond Concepts: Nonconvecting Salt o $90^{\circ} \mathrm{C}$ - Binary Cycle Hand Calculations 
FIGURES

2.1 Solar Pond Electrical Power Generation - Cost of Power Versus Pond Cost . . . . . . . : . . . . . . . 2.2

3.1 Solar Pond Schematic . . . . . . . . . . . . . 3.2

3.2 Efficiency Curve - Mean Energy Converted by Means of a Carnot Engine Recoverable from Ponds of Various. Depths at the Most Efficient Temperature of Operation

3.3 Elata-Levin Experiment and Results . . . : . . . . . 3.15

3.4 Nonconvecting Salt Water Pond with Membrane Partition . . 3.18

3.5 Phase Relationship Between Pond Temperature and

4.1 Dike Cross Section of Reference Pond . . . . . . . . . 4.5

4.2 Plan View of Reference Nonconvecting Pond System . . . . 4.8

4.3 Alternate Layer Removal System . . . . . . . . . 4.10

4.4 Nonconvecting Salt Pond Cross Section . . . . . . 4.12

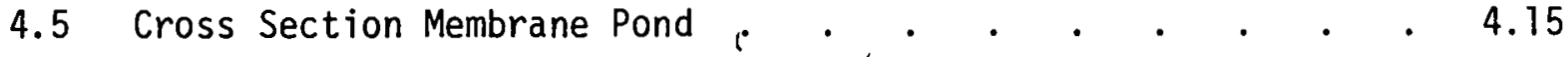

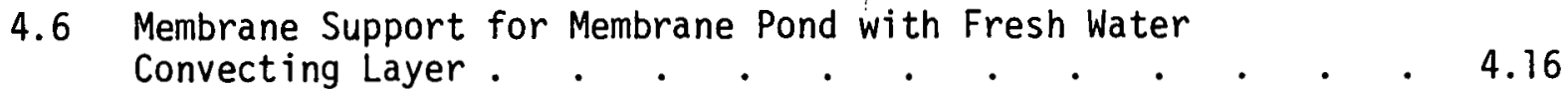

4.7 Cross Section of Gelled Pond . . . . . . . . . . . 4.18

4.8 Shallow Solar Pond Concept by. LLL . . . . . . . . . 4.20

4.9 Storage Pond for Shallow Solair Pond Concept . . . . . . 4.21

4.10 Binary Fluid Cycle Power Plant . . . . . . . . . . . . 4.22

4.11 Flash Steam Plant . . . . . . . . . . . . . . . 4.23

4.12 Thermodynamic State Points for Binary Fluid Cycle • • • 4.31

4.13 State Point Values of Working Fluid . . . . . . . . . 4.33

4.14 Vaporizer Pinch Point Temperature . . . . . . . . . 4.35

4.15 Steam Recovery Versus Temperature for $90^{\circ} \mathrm{C}$ Solar Pond . $\quad 4.41$

4.16 Steam Condenser-Cooling Tower Heat Transfer Diagram . . . 4.46

5.1 Solar Pond Electrical Power Generation - Cost of Power Versus Pond Cost. . . . . . . . . . . . 5.11

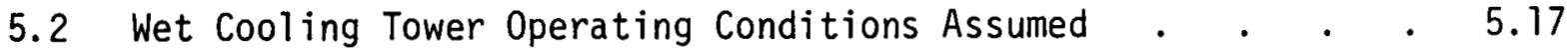


5.1.2 Shallow Pond Cost Estimate $\quad . \quad$. $\quad . \quad . \quad . \quad 5.6$

5.2 Pond Operating Cost Estimates . $\quad . \quad$. . $\quad . \quad . \quad . \quad 5.7$

5.2.1 Pond Operating Costs

5.2.2 Operating Cost Estimate - Shallow Solar Pond . . . . . . . . . . . . . 5.7

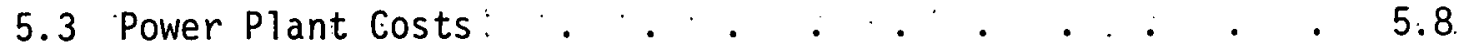

5.4 Thermal Energy Cost Estimate . . . . . . . . . . 5.16

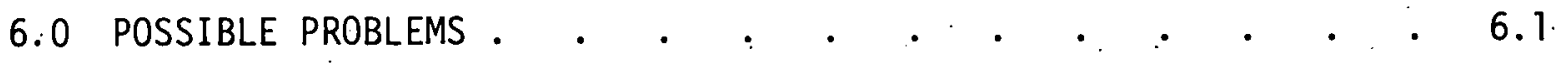

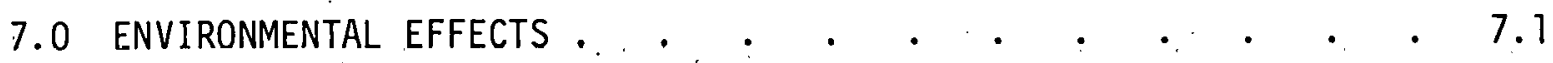

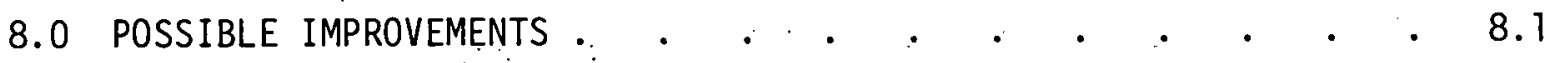

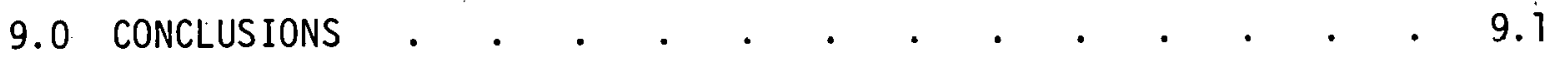

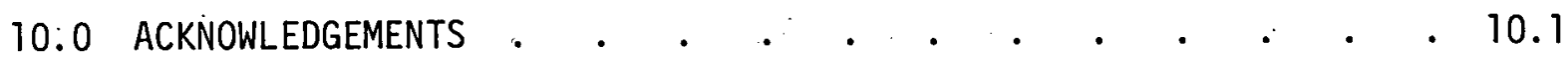

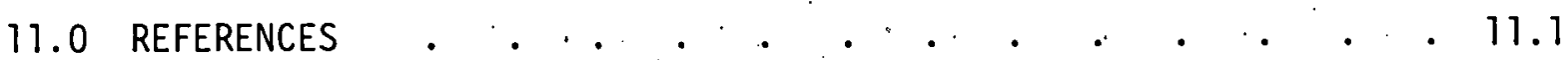




\subsection{INTRODUCTION}

The objectives of this study are to:

1. Identify the various solar pond concepts for electric power generation; including but not limited to:

a. nonconvective salt gradient solar pond,

b. ponds with various plastic or other membranes at suitable locations to minimize or eliminate convection,

c. ponds which are totaliy or partially gelled to reduce or el iminate convection, and

d. shallow convecting ponds;

2." analyze and compare the performance of these various concepts; and

3. estimate the pond cost and overall power plant system cost for each concept assuming the nonconvective gradient salt pond as the base case.

Solar ponds are generally relatively low temperature systems so that the conversion efficiency from thermal energy stored in the pond to electric energy is small. The energy in the pond may be more efficiently used for purposes other than power generation. For this reason, pond costs are related to energy production separately as well as in the power. plant context.

The approach includes a preliminary design of several power plant systems based on solar pond concepts, and performance and economic evaluation based on these preliminary designs.

Battelle-Northwest is developing a computer program on geothermal power production (1) for ERDA which is applied to this study. The geothermal program (GEOCOST) considers the geothermal field and power plant 
economics. For this study, the solar pond was substituted for the geothermal field. Power plant considerations are comparable. The utilization of this program thus provides an extensive analysis of economics for electricity production.

The GEOCOST program includes flashed steam, binary, and hybrid cycles for low temperature operation. Several man years of effort have been spent in the development of low temperature power cycle costs.

Because temperatures involved in the solar pond are lower than those generally considered for geothermal applications, GEOCOST is not directly applicable. Some corrections have been made and some operations have been pérformed by hand.

It should be noted that the time and dollars for this solar pond study were limited. The time from authorization to completion of the criginal study was 5 weeks and the manpower allocation was approximately 14 man weeks. An additional 3 man weeks has since been spent checking and editing. The general conclusions are believed to be sound, but specific detail should be considered preliminary. 


\subsection{SUMMARY}

Four solar pond concepts were reviewed: 1) nonconvecting salt, 2) nonconvecting "salt with membrane; 3) gelled, and 4) shallow convecting pond.

Because there are many technical unknowns in the first three, the results arrived at are uncertain. Assuming that solar ponds are shown to be technically practical, the magnitude of pond costs illustrated is considered reasonable. However, several factors could change the costs up or down by $50 \%$ or more. A comparison of the three concepts is hence not at all conclusive.

In the case of the shallow convecting pond, pond costs are based on Lawrence Livermore documents and demonstrated technology.

A $10 \mathrm{MW}_{\mathrm{e}}$ plant was used for purposes of analysis. This requires a pond with an area of approximately $16,000,000 \mathrm{ft}^{2}\left(1.49 \mathrm{~km}^{2}\right)$ or 4,000 $\mathrm{ft}(1.2 \mathrm{~km})$ on a side. Both flash steam cycles and binary cycles using isobutane as the working fluid were evaluated. The binary cycle is considered more realistic at the present time because turbine technology for steam at the low temperatures considered is not developed.

The variation in power cost with pond cost is illustrated in Figure 2.1. With a zero pond cost and a binary cycle operating at $90^{\circ} \mathrm{C}$, the cost of electric power production would be approximately $45 \mathrm{mill1s} / \mathrm{kW}-\mathrm{hr}$. At a pond cost of $\$ 32,000,000$ or above $\$ 2.00 / \mathrm{ft}^{2}$, the cost of power would be approximately $125 \mathrm{mills} / \mathrm{kW}-\mathrm{hr}$. These costs are based on fixed charges of approximately $16 \%$ per year, which is probably high. Fifteen percent is more frequently used today, and with present interest rates, $13-14 \%$ could be reasonable. However, time did not allow for iterations.

Assuming technical feasibility within the economic framework developed here, solar ponds might possibly produce thermal energy in the range of $\$ 2.00-\$ 4.00$ per million Btu.

General conclusions based on preliminary analysis are:

- Electrical power production from solar ponds is not cost competitive with other systems, based on current central station power producing technology. 


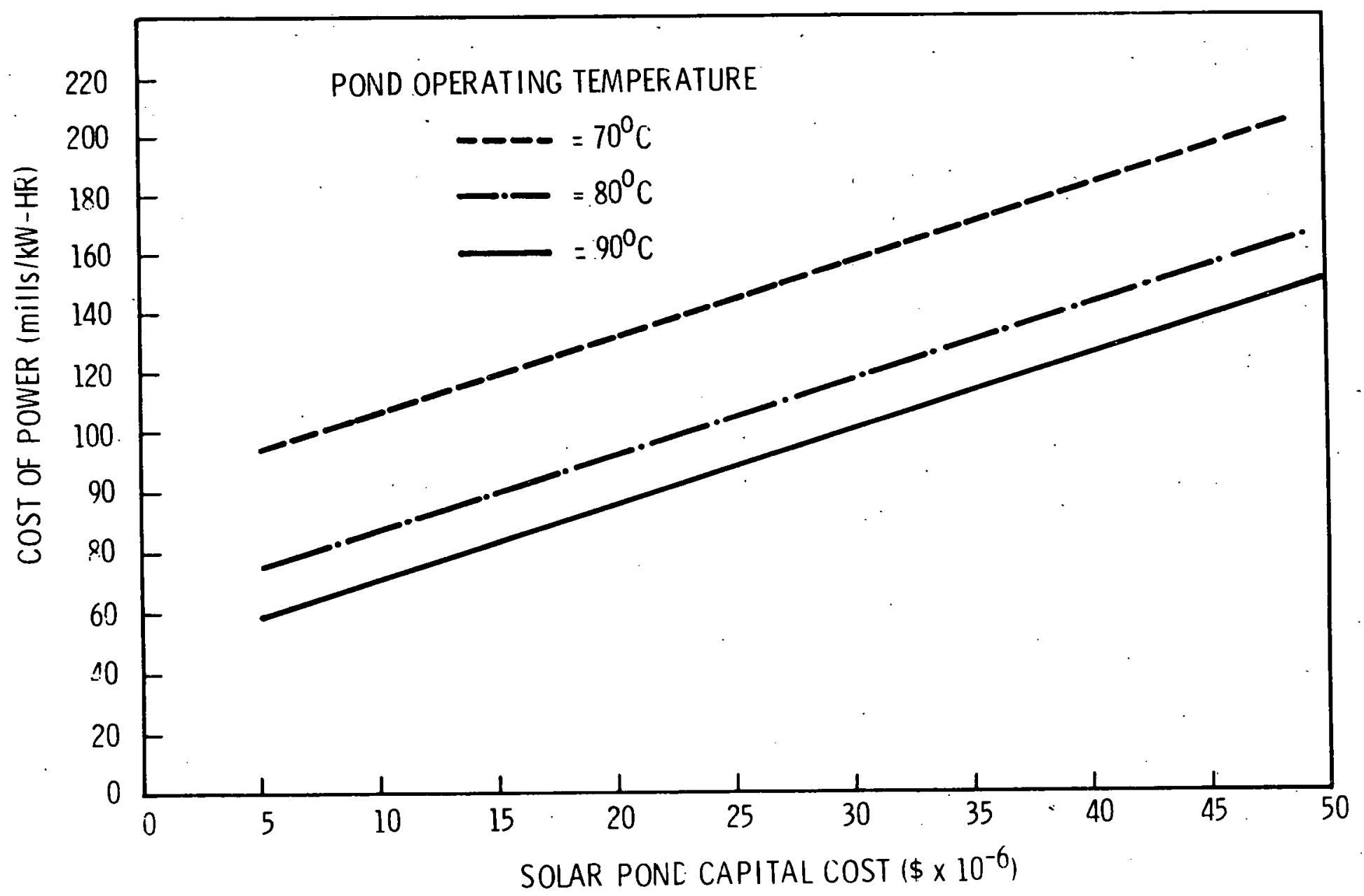

FIGURE 2.1. Solar Pond Electrical Power Generation - Cost of Power Versus Pond cost (based on $10 \mathrm{MW}$ gross power plant binary/isobutane power cycle) 
- The cost of power production with solar ponds is in a range such that additional evaluation may be warranted for unique circumstances such as isolated sites.

- Based on the cost of Btu's produced by solar ponds, it is quite possible that they can be competitive with other energy systems in some circumstances, if they are technically practical.

- The technical feasibility of nonconvecting solar ponds is not established.

- There are a number of problems which could prevent them from being widely used.

Results of the economic analysis are summarized in Table 2.1. 
TABLE 2.1. Ten Megawatt Electrical Solar Pond Concepts Economic Summary

\begin{tabular}{|c|c|c|c|c|c|c|c|}
\hline & \multicolumn{2}{|c|}{ Nonconvecting } & \multirow[b]{2}{*}{ Membrane } & \multirow{2}{*}{$\mathrm{Gel}$} & \multirow{2}{*}{ Shallow } & \multirow{2}{*}{$\begin{array}{l}\text { Free* } \\
\text { Salt }\end{array}$} & \multirow{2}{*}{$\begin{array}{l}\text { Geothermal } \\
\text { Reference }\end{array}$} \\
\hline & Steam & Binary & & & & & \\
\hline $\begin{array}{l}\text { Pond cost } \\
\left(\$ \times 10^{6}\right)\end{array}$ & 41.6 & 41.6 & 28.0 & 41.4 & 31.1 & 11.5 & 4.5 \\
\hline $\begin{array}{l}\text { Plant capital } \\
\text { cost }\left(\$ \times 10^{6}\right)\end{array}$ & 17.148 & 7.107 & 7.. 107 & 7.107 & 7.107 & 7.107 & 7.132 \\
\hline $\begin{array}{l}\text { Net power } \\
\text { output. }\left(\mathrm{MW}_{\mathrm{e}}\right)\end{array}$ & 6.652 & 7.653 & .7 .653 & 7.653 & 7.653 & 7.653 & 6.240 \\
\hline $\begin{array}{l}\text { Installed cost } \\
\left(\$ / \mathrm{kW}_{\mathrm{e}} \text { net }\right)\end{array}$ & 8,690 & 6,366 & 4,588 & 6,339 & 4,993 & 2,236 & 1,864 \\
\hline $\begin{array}{l}\text { Cost of power } \\
(\mathrm{mi} 1 \mathrm{ls} / \mathrm{kW}-\mathrm{hr})\end{array}$ & 203.6 & 105.2 & 114.4 & 149.6 & 124.9 & 71.1 & 87.1 \\
\hline
\end{tabular}

* Free salt is the case where the solute for the nonconvecting salt gradient pond is available at no cost. 


\subsection{SOLAR POND TECHNOLOGY}

Solar ponds, as presently conceived, fall into two categories: nonconvecting ponds and shallow convecting ponds. Nonconvecting ponds include conventional ponds proposed by Tabor, (2) those with membrane barriers to aid stability proposed by Rabl and Nielsen ${ }^{(3)}$ and ponds containing gels proposed by Shaffer. (4). The convecting pond discussed here is the shallow pond developed by Clark, Day, Dickinson. and Wouters et al. at the Lawrence Livermore Laboratory. (5)

\subsection{Nonconvecting Salt. Water Pond}

The more conventional of the nonconvecting solar ponds is the salt water pond without membrane barriers, but possibly with a cover. This pond type was the first of the nonconvecting pond concepts and will be referred to throughout this report as the conventional nonconvecting pond.

\subsubsection{Description}

The nonconvecting solar pond is a nonconvecting, transparent, liquid pool in which temperature increases with depth. In $1948 \mathrm{Dr}$. Rudolph Bloch suggested that a density gradient could be formed by stratifying salt solutions of various densities such that the density increases with increasing depth. $(6)$ The stabilizing concentration gradient can overcome the effect of a destabilizing temperature gradient. This principle is shown schematically in Figure 3.1. (7)

Solar energy, which impinges on the pond (collector) surface, is partially reflected and partially transmitted and absorbed. Convection is prevented by establishing an opposing density gradient with a solute. Since water is almost opaque to the far infrared only the short wavelengths are reported ${ }^{(8)}$ to penetrate up to $100 \mathrm{~m}$ of water. Thermal energy near the pond bottom will be trapped because of the opaque nature of water to far infrared radiation, the relatively poor conductivity of water, and the inability of the salt solution to convect. Energy extraction must be from this bottom layer. 


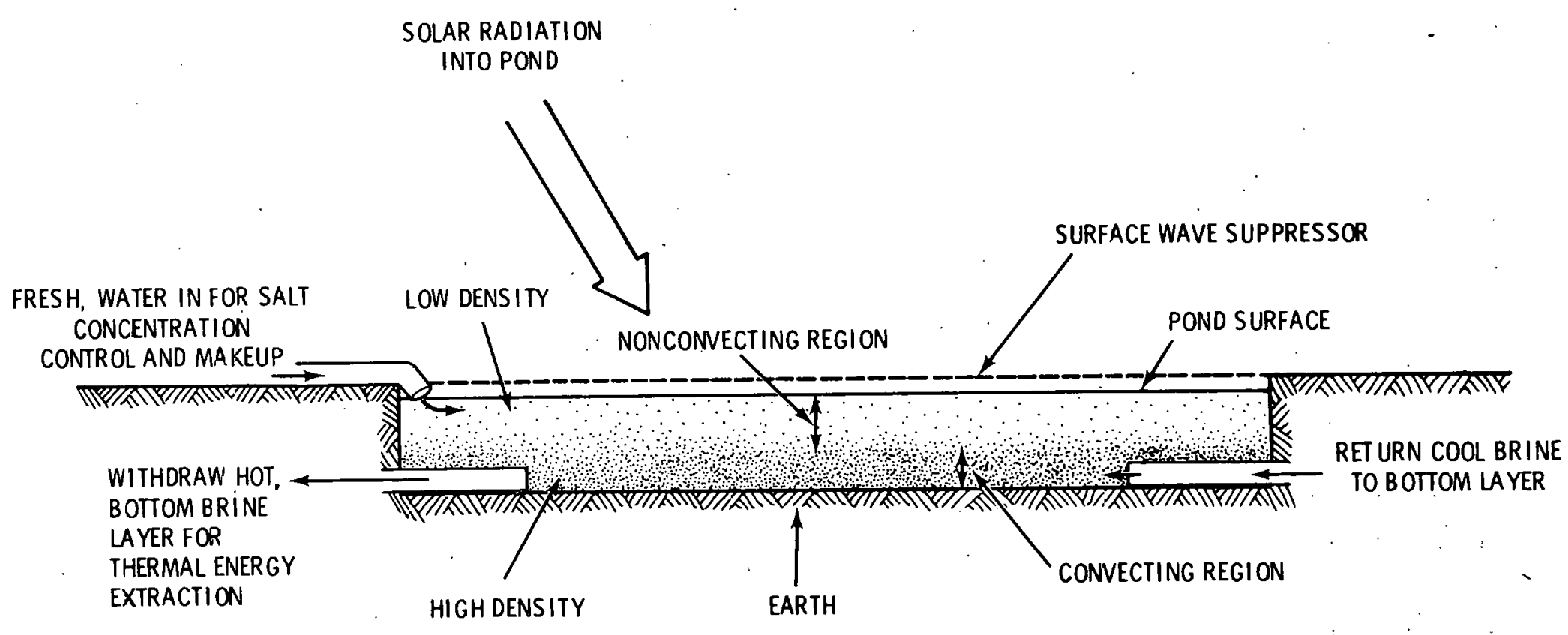

FIGURE 3.1. Solar Pond Schematic (7) 
Physically the pond absorbs solar energy throughout its bulk in a manner which depends on the local insolation. Only the 0.2 to $0.9 \mu \mathrm{m}$ wavelengths reach the bottom of ponds 1 to $10 \mathrm{~m}$ deep. The energy $I(x)$ reaching any depth $x$ below the pond surface can be approximated by:

$$
I(x, t)=\tau I_{0} \quad \sum_{i=1}^{4} \eta_{j} e^{-\mu_{j} x}
$$

where $I_{0}$ is the insolation at the surface of the pond, $\tau=$ transmission coefficient, $\mu_{i}$ is the absorption coefficient for a given range of wavelengths, and $\eta_{i}$ are constants which can be adjusted to fit the measured energy distribution of sunlight at various depths $x$. Rabl and Nielsen have shown this to be good within $3 \%$ of the values quoted by Defant ${ }^{(8)}$ for seawater.

The general one-dimensional heat conduction equation has been solved by Weinberger $(9)$ using an insolation expression similar to the above; and expressing $I_{0}$ as a sum of an average and periodic insolation.

From this solution the pord temperature is shown to lag behind the insolation by about two months. This will vary with the energy extraction rate. Assuming a constant working temperature of the hot fluid at the bottom of the pond (triat is to say, once the pond reaches temperature all energy reaching the pond bottom is extracted at a constant temperature) and by optimizing energy extraction by means of a Carnot engine, the mean energy; overall solar to mechanical or electric conversion efficiency, and optimum temperatures were determined. These values are reproduced as a function of pond depth in Figure 3.2.

The collection efficiency can be found by optimizing the thermal energy extraction rate and comparing the resulting extraction rate with the insolation. In this manner Weinberger obtained an efficiency of collection between 25 and $30 \%$ for a $200 \mathrm{~W} / \mathrm{m}^{2}$. insolation and a pond $1 \mathrm{~m}$ deep.

From the above discussion, the pond can be characterized by its optimum working temperature, its phase lag relative to insolation, and its collection efficiency. But less obvious intrinsic characteristics are vitally important to the pond operation. For discussion purposes, we assign the following designations to these characteristics: i) diffusion 
THIS PAGE

\section{WAS INTENTIONALLY LEFT BLANK}


is the migration of salt due to the concentration gradient necessary to make the salt water. pond nonconvective, ii) storage is the intrinsic thermal storage in the nonconvecting pond and iii) stability refers to the ability of the pond to remain nonconvecting over a range of temperatures, concentration gradients, and outside influences.

\subsubsection{Diffusion}

Any time there exists a concentration gradient in a material and there is ample thermal energy to activate an atomic or molecular migration, there will exist diffusion of the solute species from high concentration regions to regions of low concentration. It is not surprising then that the nonconvecting salt water ponds exhibit considerable diffusion of salt to the surface of the pond $\left(0.063 \mathrm{~kg} / \mathrm{m}^{2} /\right.$ day $)$. (9) The tendency is toward destruction of the density gradient. To keep the pond functioning, the concentration gradient must be restored on a continuing basis. Two methods have been proposed for doing this. One method suggests the salt which diffuses to the surface be removed by washing a top saline layer away and replacing it with water of a lower salinity; salt must be restored to the bottom of the pond. The other method, proposed by Tabor and Matz (10) extracts hot brine from the pond bottom at a rate such that salt which migrates upward in the moving reference frame of the falling pond (falling, because water is extracted from the lower regions only) finds itself stationary with respect to the reference frame fixed in the earth. Fresh water, or a low salinity solution, must be simultaneously added to the top regions of the pond to keep the pond depth constant. Enough salt or highly concentrated brine must be put back into the pond bottom regions to maintain a suitable density gradient.

\subsubsection{Storage}

Thermal conversion of solar power to useful electrical power is a concept that depends heavily on energy storage. Whether the system supplies. power during peak demand or continuous conversion it is necessary that either thermal, electrical, or chemical energy storage be included in the system design if full advantage of the insolation is to be realized. The nonconvecting solar pond concept does just this; it stores the solar energy collected 


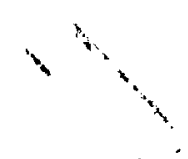

and releases thermal energy on demand. This is analogous to the hydroelectric dam which is essentially a potential energy collection and storage device.

Storage of thermal energy is inherent in the nonconvecting systems. Energy is trapped in the liquid near the pond bottom and is lost only by slow thermal conductivity to the surface or it is absorbed by the surrounding earthen containment; it is assumed that parasitic losses by ground water are negligible. It is assumed that the side walls are insulated so that all earth storage will be beneath the pond. Then the earth temperature during warm-up is given by:

$$
T_{g}(y, t)=T_{g}(0) \operatorname{erfc}\left(\frac{Y}{2 \sqrt{k_{g}^{t}}}\right)
$$

where $T_{g}(0)$ is the initial surface temperature of the earth and $y$ and $k g$ are vertical distance below the earth surface and thermal diffusivity of the earth, respectively; time is represented by $t$.

This implies that the approach to steady state goes as $1 / \sqrt{t}$. Since the depth in the earth for temperature oscillations of frequency $\omega$ to be damped to $1 / e$ of their. surface value is $\frac{2}{\omega}$, this can be taken to be the depth of useful storage in the earth. (3). For soil with a $4.6 \times 10^{-7} \mathrm{~m}^{2} / \mathrm{sec}$ diffusivity, this amounts to about $2 \mathrm{~m}$. Approximately 1 year is necessary for the earth at this temperature to reach $1 / e$ of its final value. Weinberger has shown that ground storage decreases the maximum rate at which energy can be withdrawn, and that this maximum energy removal rate increases with operating time. For example, at an operating temperature of $98^{\circ} \mathrm{C}$ and an operating time of 0.5 and 4 years the optimum energy removal rate changes from 80 to $93 \%$, respectively, of that attained after an infinite time of operation. This is due to the relatively slow manner in which the ground approaches steady state. Some solar energy is being absorbed by the ground during this time, and until steady state is reached this absorption. decreases the rate of energy withdrawal if the temperature of the hot brine is to remain constant.

This energy absorption is dependent on the thermal diffusivity of the earth and operating temperature of the fluid. Energy stored in the ground 
can be recovered, but only at the expense of decreasing the working temperature of the brine and therefore decreasing operating efficiency of the power plant. Of course, if storage were not available the brine would reach its peak for energy withdrawal rate sooner. But in the advent of relatively long periods of low insolation this withdrawal rate would approach zero very quickly. Ground storage, on the other hand, allows for energy withdrawal (albeit at a lower conversion efficiency) during these low insolation periods. In fact, $1 \mathrm{~m}^{3}$ of "average" soil can store about $2 \times 10^{6}$ Joules per degree. The temperature of the soil at depth $x$, during net energy extraction from the soil, can be estimated by:

$$
T_{g}=T_{g}(0) \operatorname{erf}\left(\frac{x}{2 \sqrt{k_{g}^{t}}}\right)
$$

This assumes for simplicity that soil temperature is initially $\mathrm{T}_{g}(0)$ and it radiates into $0^{\circ}$ water. This implies that soil temperature at some average depth, say $0.5 \mathrm{~m}$, decreases to $85 \%$ of its initial value in about 1.5 days. If the initial temperature of the ground is $95^{\circ} \mathrm{C}$, this corresponds to a $14^{\circ}$ change and hence an average $122 \mathrm{~W} / \mathrm{m}^{2}$ contribution from the soil: Therefore, thermal energy stored in the soil might be used for a period of a few consecutive days. If lower temperatures are useful this use period can be extended considerably.

\subsubsection{Stability}

To obtain a nonconvecting salt water pool without the use of artificial barriers, the decrease in density with depth which would accompany the increase in temperature in a uniform-concentration solution is cancelled by arranging for the salt concentration to increase with depth, so that the net effect is an increase in density with depth.

$$
\frac{d \rho}{d x}=\left(\frac{\partial \rho}{\partial T}\right)_{c} \frac{d T}{d x}+\left(\frac{\partial \rho}{\partial c}\right)_{T} \frac{d c}{d x}>0
$$

where $\rho, T, x$ and $c$ are density, temperature, distance below the surface and concentration, respectively. As an initial condition to be fulfilled in constructing a pond, such a concentration gradient is readily obtained. Maintaining it, however, appears to be another matter. That it can be maintained indefinitely is yet to be established. Naturally-occurring 
solar pond effects have been observed (e.g., at Medve Lagoon, Lake Vanda, Los Roques), experimental solar ponds have been built, and approximate analytical models of related situations are being developed.

Nielsen ${ }^{(11)}$ has been able to control convecting layer growth in $\mathrm{NaCl}$ ponds by injecting saline solutions of an appropriate density into the convecting layer region. This technique has been used successfully by Nielsen to actually decrease the thickness of convective layers which form adjacent to the pond bottom.

Several critical questions remain to be answered, however, before the potential of the solar pond as an effective energy collector can be properly evaluated. (12) Most of these questions have to do with whether or not long-term stability is possible and what conditions or arrangements are necessary to obtain it. In particular, what conditions are necessary to avoid the instabilities associated with the spontaneous occurrence and growth of convection cells which destroy the density gradient?

As discussed in the preceding section, some means of maintaining the concentration field in the pool against the effects of diffusion are necessary, but there are still other difficulties. Such a pool is in a sort of metastable state in that, if the concentration gradient were to be destroyed by stirring or mixing the pond could not spontaneously restore it. Nor would just the heating of the pond restore it, since convection cells would develop first. This is important because some evidence is available which suggests that naturally occurring mechanisms may, in the absence of corrective action, bring about the occurrence and slow growth of a convecting layer in the initially gravitationally-stable pond. This would lead eventually to the destruction of the energy-storing capability of the pond. Weinberger (9) develops a stability criterion and suggests that maintaining an adequate density difference $\left(340 \mathrm{~kg} / \mathrm{m}^{3}\right)$ at the bottom and top of the pond will prevent an increase in oscillatory motion with time. However, there appears to be more. A model by George Veronis $(13,14)$ predicts three different possible modes of convection for a liquid layer subjected to a destabilizing temperature gradient which is initially 
nonconvecting due to the effects of a stabilizing concentration gradient: 1) spontaneously-occurring steady convective motion, as in Benard cell formation; 2) overstable oscillatory motion occurring at a smaller Rayleigh number* (smaller $\Delta T$ ); and 3) a disturbance-initiated, finite amplitude steady motion, which would be sustained at a Rayleigh number which is still smaller, in some cases almost negligible.*ᄎ

According to this model, an initially nonconvecting layer maintained at higher salinity at the bottom than at the top, heated from below and cooled from above, if sufficiently disturbed, will develop and mainta in finite-amplitude steady convection at extremely small Rayleigh numbers. An adequate disturbance would be one which mixes the interior to uniformity so that the temperature and concentration gradients are confined to the boundary regions. After the cessation of such a disturbance, the destabilizing temperature gradient would create convection cells in the interior before a stabilizing density gradient could establish itself. This implies that, in constructing a stable solar pond, the density gradient must be established before heating takes place, or it will not be established. This appears to be confirmed by the experience to date. This would

* Rayleigh Number $R_{a}=\frac{g a h^{3}}{K \nu} \Delta T$

$\mathrm{g}=$ local acceleration due to gravity

$\alpha=-\frac{l}{\rho}\left(\frac{\partial \rho}{\partial T}\right)_{c}, \rho=$ density, $c=$ solute concentration

$\Delta T=$ temperature difference over convection cell height

$h$ = convection cell height (not pond depth)

$\kappa=$ thermal diffusivity

$\nu=$ kinematic viscosity

** In considering these convective mode possibilities, it is useful to keep in mind that the shape of the temperature profile in a solar pond varies widely on a regular basis. To relate the models which speak of "heating from below" or "heating from above" to the solar pond it is necessary to do so on the basis of the local temperature gradient. For a discussion of the temperature profile variation see Eliseev, Usmanov and Teslenko(15) and Turner. (16) 
probably make pond cleaning by stratified extraction difficult since the disturbed region may not be able to reestablish its density gradient.

The overstable oscillatory mode predicted by Veronis $(13)$ has been observed in laboratory experiments by Shirtcliffe ${ }^{(17)}$ and by Turner and Stommel. (18) According to Schechter, Prigogine, and Hamm, (19) the conditions under which this mode can be expected are related to the Soret ${ }^{(20)}$ effect. This model indicates that, for a layer subjected to a destabilizing temperature gradient, this mode can be expected with positive Soret coefficients, and that the greater the Soret coefficient, the smaller the Rayleigh number at which it can occur. This is further discussed and summarized by Velarde and Schechter (21) and by Hurle and Jakeman. (22) The stability difficulties described by Tabor ${ }^{(23)}$ and Tanner ${ }^{(20)}$ with $\mathrm{NaCl}$ salt ponds ( $\mathrm{NaCl}$ has a positive Soret coefficient) are not inconsistent with this model. Nor is the growth of the convecting layer in the upper part of the $\mathrm{MgCl}_{2}$ salt pond constructed by Tabor, where it is noted that the steepest destabilizing temperature gradients may occur near the surface and spread downward during the cooling part of the daily cycle as the pond is being brought up to operating conditions. (15) Tanner ${ }^{(20)}$ reported $\mathrm{MgCl}_{2}$ as one of a few salts which yielded separations in Soret effect tests which were too small to be measured. Again, a very small $\mathrm{MgCl}_{2}$ Soret coefficient is not inconsistent with the slowness of the layer growth noted by Tabor. The third mode indicated as possible by Veronis' model, spontaneous steady convection, would occur for greater Rayleigh numbers than the overstable oscillatory mode, so the latter is the mode predicted for the onset of convection.

\section{1 .2 Uperation}

Pond operation requires 1) preservation of the salt gradient, 2) maintenance of pond transparency, and 3) use of optimum energy extraction techniques.

\subsubsection{Preservation of the Density Gradient}

Since a concentration gradient is necessary to overcome the buoyant forces due to thermal expansion in a solar pond, salt diffusion from bottom 
to surface will be continual. As noted in the discussion in the preceding section on Weinberger's stability criterion and his calculation of the salt gradient necessary for stability, for a pond using $\mathrm{MgCl}_{2}$, a $340 \mathrm{~kg} / \mathrm{m}^{3}$ difference in density must be maintained between the surface and bottom layer. Weinberger also calculates that $0.063 \mathrm{~kg} / \mathrm{m}^{2}$. day of salt must be removed each day and replaced in the lower layer of the $1 \mathrm{~m}$ deep pond. For a $1 \mathrm{~km}^{2}$ pond this means that 63 tonnes of salt must be controlled during each day of operation.

Tabor (23) reports that washing the surface with fresh water or low concentration salt solution while maintaining the bottom concentration would provide a satisfactory approach to this problem. As previously discussed, Tabor and Matz suggest a "falling pond" arrangement as an improved way of maintaining top and bottom concentrations when the energy-extraction process involves a flash evaporation of the bottom brine. In this process, brine from the hot bottom layer of the pond flows into a low pressure flash evaporator where a pressure drop is accompanied by a small temperature drop and the evaporation of some of the water from the brine. The vapor and (now more concentrated) brine are separated and leave the evaporator in two separate streams. The vapor flows on to drive a turbine and the brine is returned to the bottom of the pond to be reheated. Water is added to the top of the pond to replace the water evaporated from the surface of the pond as well as the water removed from the bottom layer brine in the evaporator. The net effect is a slow downward flow of the water in the pond against the upward diffusion of the salts. If the two velocities are of the same magnitude, the salts, and consequently the salt gradient, are stationary.

Tabor indicates that the downward water velocity required to balance the diffusion of the salts is less than $1 \mathrm{~mm} /$ day. This would impose a minimum requirement on the average evaporation rate in the flash evaporator. Greater flashing rates, if dictated by energy-extraction rate requirements, could be accommodated by returning to the brine as much of the vaporized water as necessary after it has been through the turbine and condenser. If a weak solution is added at the surface instead of fresh 
water, the downward motion of the pond water would result in a net flow of salt to the bottom layer. Salt would have to be removed after flash evaporation at the rate at which it is supplied to the surface.

Another possibility might be a saturated-solution pond composed of a solution in which the increase of solubility with temperature is substantial enough to provide the density gradient necessary for stability. Potassium nitrate, ammonium nitrate and calcium chloridedihydrate are salts which fit this category. It appears that such a pond could automatically maintain the desired gradient, provided that convective stability requirements could be met. A satisfactory energy extraction process for such a pond would probably be difficult, however.

\subsubsection{Pond Transparency}

Transmission properties of a solar pond can be seriously altered by particulate debris. Particulate matter may be carried in the air and deposited in the pond, or may originate in the pond walls or bottom and migrate by currents and buoyancy forces into the interior. In either case, the particulates will seek a level identified by the localized pond density and the density of the particulates.

Tabor and Matz report an exceptionally bad problem in one of their experimental ponds which has been built on a clay bed overlaying marshy ground. At start of operation, the lower layer of brine warmed from 20 to $70^{\circ} \mathrm{C}$ and the earthen bottom temperature reached $41^{\circ} \mathrm{C}$ some 0.2 to $0.3 \mathrm{~m}$ into the earth. At these temperatures $\mathrm{CO}_{2}$ and $\mathrm{H}_{2} \mathrm{~S}$ gas bubbles were released from the bottom in sufficient quantities to seriously disturb density gradients, prevent settling of debris, and also transport debris up from the bottom into the fluid; evidently bacterial decomposition was occurring in the marshy bottom. Pond bottom materials are important--pollution caused by bacterial decomposition must be avoided.

Tabor and Matz have worked on an experimental pond with a butyl rubber lining designed to vent gas generated in the pond bottom. Results of this experiment have not been published. Delyannis and Piperoglou ${ }^{(24)}$ lined solar distillation basins in Greece with butyl rubber sheets and found that in 
the spring wild grass grew through the rubber sheeting. Lawand ${ }^{(25)}$ reports that: $0.8 \mathrm{~mm}$-thick butyl rubber sheet has been successfully used to line solar distillation bays in the West Indies. Morrison, Dodge, Merriman, and Ellsperman ${ }^{(26)}$ conducted a field evaluation study of various lining materials used in brine disposal ponds. For seepage control, the flexible membrane linings were most effective; soil sealants were found to be least effective.

A pond need not die from particulate pollution. It may be that the particular layer where debris has settled can be cleaned by using a selective stratified layer extraction process relative to removal of the heated bottom layer. Indeed, it has been proposed by Benton, et al., (27) that water reservoirs use this technique to control water quality downstream. The analysis makes this method look particularly suitable for removing polluted layers in a solar pond; the layer could be filtered and injected back to its appropriate level. Air-transported particulates can be kept from the pond by providing a transparent cover which is periodically washed. As mentioned previously, theory suggests this method will cause convection cells and destroy pond stability. However, the rather limited experience with ponds suggests this may not be the case. Further research is needed in this area.

\subsubsection{Energy Extraction}

The obvious techniques of extracting energy from large ponds using a separate working medium may be prohibitively expensive. For example, one might conceive of a network of high thermal conductivity pipes on the pond bottom, with a fluid flowing through the pipes to extract energy from the pond. Because of low thermal conductivity of stationary water in the pond this technique would be very inefficient in a nonconvecting layer. For this reason, Tabor (2) proposed using a stratified layer extraction technique whereby the entire bottom high-density layer is extracted, its energy removed by passing through a heat exchanger, and the brine returned without pond mixing to the bottom. Such selective withdrawal techniques have been studied theoretically and experimentally $(27,28)$ but there is little published experimental information on stratified extraction from thermohaline ponds. 
Tabor and Matz $(10)$ report that experiments at the Technion in Haifa show stable horizontal flow of a layer at the bottom of a solar salt pond can be achieved. The example stated is that over a length of $500 \mathrm{~m}$, with a vertical density gradient of $3.3 \times 10^{-3} / \mathrm{cm}^{4}$, a stable layer flows from the pond through a $0.15 \mathrm{~m}$ high aperture at a rate of $1.5 \mathrm{l} / \mathrm{sec} / \mathrm{m}$ width; details of these experiments were reported by Elata and Levin. ${ }^{(29)}$ Daniels ${ }^{(30)}$ has detailed some of the results of these experiments and compared results with experimental stratified withdrawal results of Debler. (31)

Elata and Levin's results are depicted schematically in Figure 3.3. The bottom layer (cross hatched) was successfully withdrawn. A secondary layer formed adjacent to the withdrawal layer; the eddy resulting from end effects of the pond is responsible for this secondary layer and yielded the density and velocity profiles shown in Figure 3.3 ( $b$ and $c$ ). Note that velocity goes to zero at a point within this secondary layer. Tabor and Matz suggest the same technique be used to remove debris which might accumulate at various depths.

Weinberger included the effect of withdrawal in his analysis of temperature variations in the solar pond. It is assumed in this analysis that a convection zone of some depth forms at the bottom of the pond. The cal-. culations show that this zone will reduce the hourly variations about the mean temperature at the bottom. In fact, by using Carsiaw and Jaeger's (32) equation for a convective zone and the diffusion equation, Weinberger shows the maximum hourly temperature variation is reduced from $14^{\circ} \mathrm{C}$ without convection to $6^{\circ} \mathrm{C}$ with a convecting layer $0.2 \mathrm{~m}$ thick. This variation is then used with an energy extraction rate relation (proportional to flow rate and temperature difference to which the working fluid is subjected) to calculate variation in convected energy due to temperature fluctuations of the pond. Results show that without a convection layer a pond operating at $98^{\circ} \mathrm{C}$ will have an excursion in the hourly rate of energy conversion which varies by 9.1\% about the daily mean. On the other hand, the maximum and minimum hourly rates with a $0.2 \mathrm{~m}$ deep convection layer are 3.4 and $3.2 \%$ greater than and less than the daily mean, respectively. 


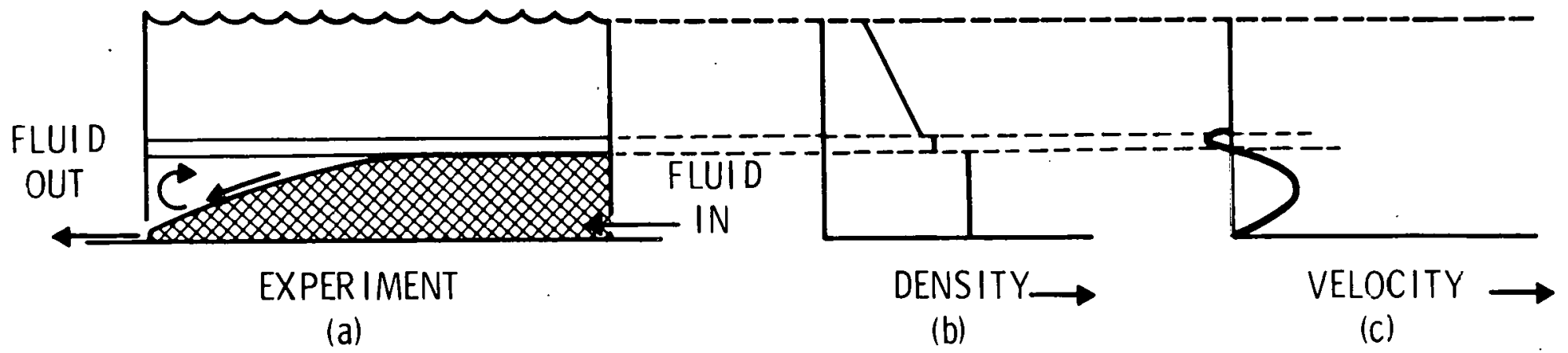

a. EXPERIMENTAL POND SHOWING THE WITHDRAWN HOR IZONTAL LAYER (CROSS HATCHED! AND EDDY MOTION

b. DENSITY PROFILE

c. VELOCITY PROFILE 
Usmanov, Eliseev, and Umarov ${ }^{(33)}$ have shown experimentally that stratified layer withdrawal of the bottom layer is possible "without violating stable operation" of a $0.23 \mathrm{~m}$ deep laboratory model pond. In these experiments energy was extracted at a rate close to the rate at which energy was absorbed in the extraction layer. These experimenters observed also that if the bottom extraction layer is separated from the nonconvecting insulation layer by a thin transparent film the temperature of this layer increases by about $8 \%$ and the bottom layer is cooled at a slower rate than when the film did not exist. This indicates some convection in the pond.

There has been little effort devoted to energy extraction from the removed layer. One concept which should be considered is suggested by Hirschmann: $(34,35)$ to flash evaporate the hot brine and use the vapor to drive a turbine. The resulting fresh water could then be used to wash diffused salt from the pond surface; the concentrated brine could be injected back into the bottom layer of the pond. Hirschmann calculates that with an average useful power of $104 \mathrm{~W} / \mathrm{m}^{2}$ available for the claude process, ${ }^{(36)}$ resulting useful mechanical energy would be about $3.4 \%$ of total heat received at the collector. It should be noted that subsequent analysis in this report indicates lower overall efficiency. Bloemer, Eibling, Irwin and Lot (37) discuss use of flash evaporation in pond-type solar stills. Hirschmann ${ }^{(35)}$. reports results of a geothermal flash-evaporation plant which began operation in 1953 with $91^{\circ} \mathrm{C}$ water and produced $200 \mathrm{~kW}_{\mathrm{e}}$.

Magnitudes of energy extraction rates for nonconvecting ponds have been caiculated, but only for operation at some optimum temperature. These calculations have been discussed briefly; the results appear in Figure 3.2 . It is emphasized that the calculations were based on operation at a constant optimum pond temperature and a given mean power conversion. For example, the optimum operating temperature for a $1 \mathrm{~m}$ deep pond is about $98^{\circ} \mathrm{C}$ and the overall conversion efficiency (including collection and conversion by a Carnot engine) is approximately $4 \%$. The corresponding mean power density of the pond approaches $10 \mathrm{MW}_{\mathrm{e}} / \mathrm{km}^{2}$. Efficiencies arrived at in preliminary 
plant design later in this report are generally less than $3 \%$, largely because of higher parasitic losses associated with the large quantities of water which must be moved to obtain power from a low Carnot efficiency system.

\subsection{Nonconvecting Membrane Pond}

Stability of nonconvecting ponds from which energy is extracted is not well established. The experimental extraction studies performed by Usmanov, Eliseev and Umarov, discussed in the preceding section, indicate that while extraction was accomplished. "without violating stable operation," cooling of the bottom layer was retarded by inserting a transparent barrier between the extracted layer and the nonconvecting isolation layer (i.e., the barrier seemed to help retain stability). This is the nonconvecting pond with membrane concept, one which Rabl and Nielsen propose should be useful in maintaining stability in ponds used for comfort heating of buildings. It is this concept which will be addressed in this section.

\subsubsection{Description}

A membrane-partitioned salt water pond is divided into two components which are separated by a transparent partition (Figure 3.4). A nonconvective component above the partition is created by producing a salt gradient which acts to stabilize the fluid in the manner described previously. This component is equivalent to the conventional nonconvective salt water pond except it does not contain a bottom convective region. The second component is, on the other hand, the hot convective region of the pond from which energy is extracted. It is located beneath the transparent partition and the black bottom foundation of the pond. The fluid in this region can be moved freely with minimum mixing in the upper (insulating) component. This would eliminate some possible. instability due to energy extraction from conventional, nonconvective ponds.

The process of operation is identical to that of the conventional nonconvecting pond. Solar energy incident on the pond.surface is partially refracted and absorbed in the bulk. The 0.2 to $0.9 \mu \mathrm{m}$ wavelengths penetrate the transparent partition and reach the pond bottom. The region beneath 


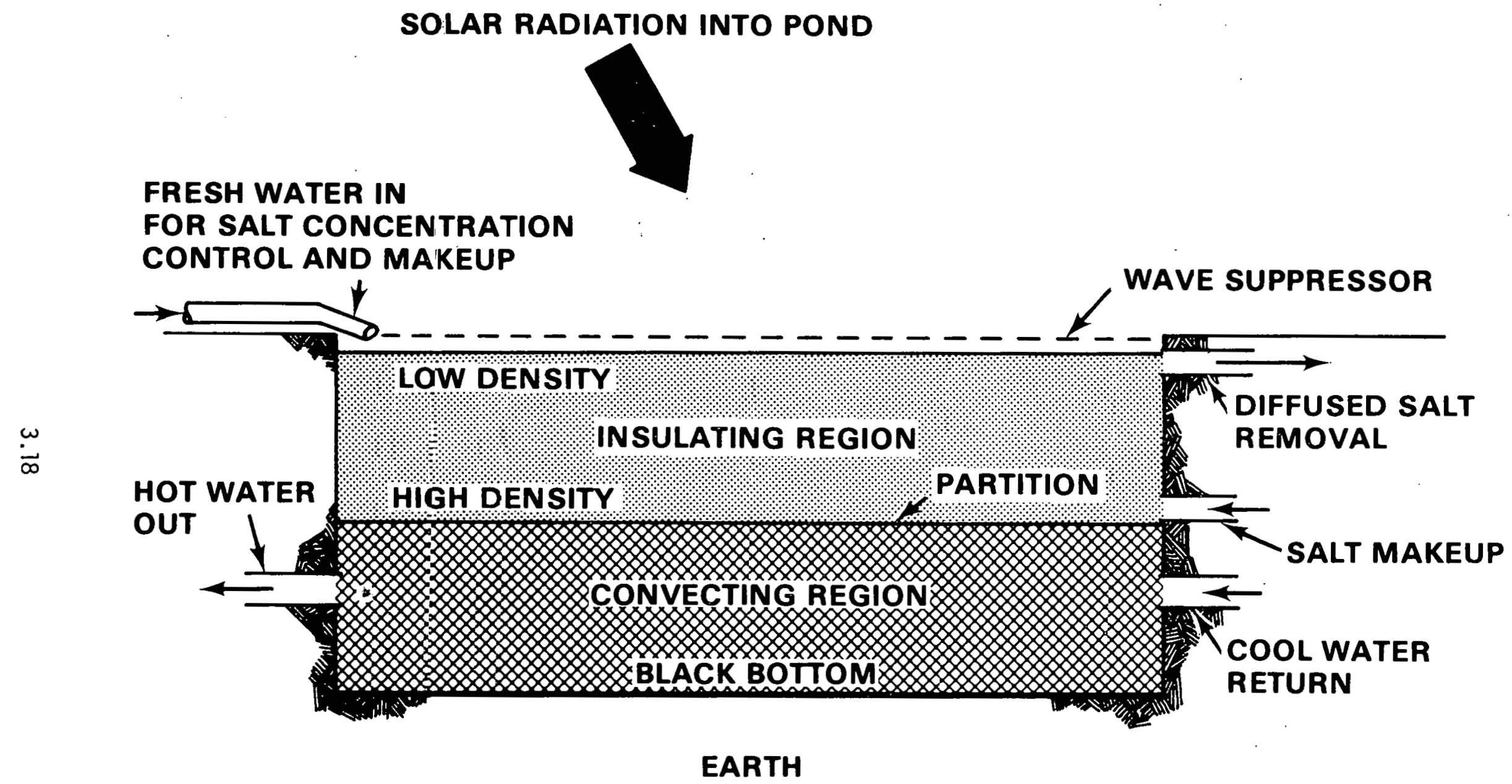

FIGURE 3.4. Nonconvecting Salt Water Pond with Membrane Partition 
the partition is thermally energized and reaches a uniform temperature by means of convection. The nonconvecting layer allows energy to escape primarily by thermal conduction, which is small (approximately $0.6 \mathrm{~W} / \mathrm{m}^{2} / \mathrm{m}$ ). Consequently thermal energy is trapped in the water and soil beneath the partition.

Since rigid partition structures would be costly, the partition would likely be a flexible membrane. If this is the case, overall loading of the partition must be small to prevent rupture. This means that either the lower layer density must be such that the convection region supports the insulation layer, or the convective region must be given a pressure head to balance gravitational forces on the partition. This latter method would allow use of fresh water for the convective fluid and eliminate corrosion problems otherwise associated with energy extraction from a brine. Since salt content is proportional to the square of the depth (with a constant gradient), the membrane allows for use of considerably less salt and hence a substantial reduction in pond cost. It would require, on the other hand, that the membrane be fixed to the pond walls by a leak-tight seam. If salt water is used as the convective layer the membrane attachment to the pond foundation may not need such a seam. Nielsten has observed the convecting layer growth rate to be small in $\mathrm{NaCl}$ ponds so that it may be that the mere positioning of a membrane with crude (loose) support (i.e., no attempt to make the membrane leak-tight around its periphery) will tend to deter layer growth. This is conjecture only; further experimentation is necessary to substantiate effects of a "loose" membrane.

\subsubsection{Diffusion}

Problems associated with diffusion of salt in the membrane pond are identical to those posed by the conventional nonconvecting pond. Salt will diffuse from the bulk to the surface at the same rates with a deterioration of the density gradient. This salt will have to be washed from the surface and make-up salt injected into the lower region of the insulating layer. 


\subsubsection{Storage}

Storage in membrane ponds is an inherent feature of these systems. Thermal energy is stored below the membrane in the fluid and in the soil (assuming ground water conditions permit this) and remains there until demand requires its release for conversion or heating purposes.

Ground storage time constants will be the same as those discussed earlier for conventional nonconvecting ponds. But temperature of the convecting region will be more controllable; i.e., temperature will depend on thickness of this region (depth below the membrane). Calculations performed by Rabl and Nielsen ${ }^{(3)}$ show this temperature decreases with increasing thickness of the convecting layer. The mean value of the temperature is independent of the thickness of the convecting layer. If the pond area is allowed to become infinite this mean temperature is given by:

$$
\bar{T} \underset{A \rightarrow \infty}{=} \bar{T}_{a}+\frac{\tau I_{0}}{\kappa_{w}} \sum_{i=1}^{4} n_{j} e^{-\mu_{i} d}
$$

where $\bar{T}_{a}$ is the average ambient temperature, $d$ is the thickness of the insulation region, and $k_{w}$ is the thermal conductivity of the pond.

These same investigators show that variations about the mean decrease with increasing thickness of the convection region while the phase lag increases. For example, increasing the convecting layer thickness from 1.8 to $3 \mathrm{~m}$ in a $160 \mathrm{~m}^{2}$ pond with a $1.4 \mathrm{~m}$ thick insulating (nonconvecting) layer decreases variations about the mean from $29^{\circ} \mathrm{C}$ to $21^{\circ} \mathrm{C}$ and increases the phase lag relative to insolation from 85 to 92 days. The pond temperature peaks about 0ctober if insolation peaks in July. This phase relation is shown in Figure 3.5 .

However, in power producing ponds with relatively high flow rates and relatively low $\Delta T$, the above phase relationships are of little significance.

\subsubsection{Stability}

The membrane pond will be more stable during energy extraction than the conventional nonconvecting pond. Fluid can be moved in the convection 


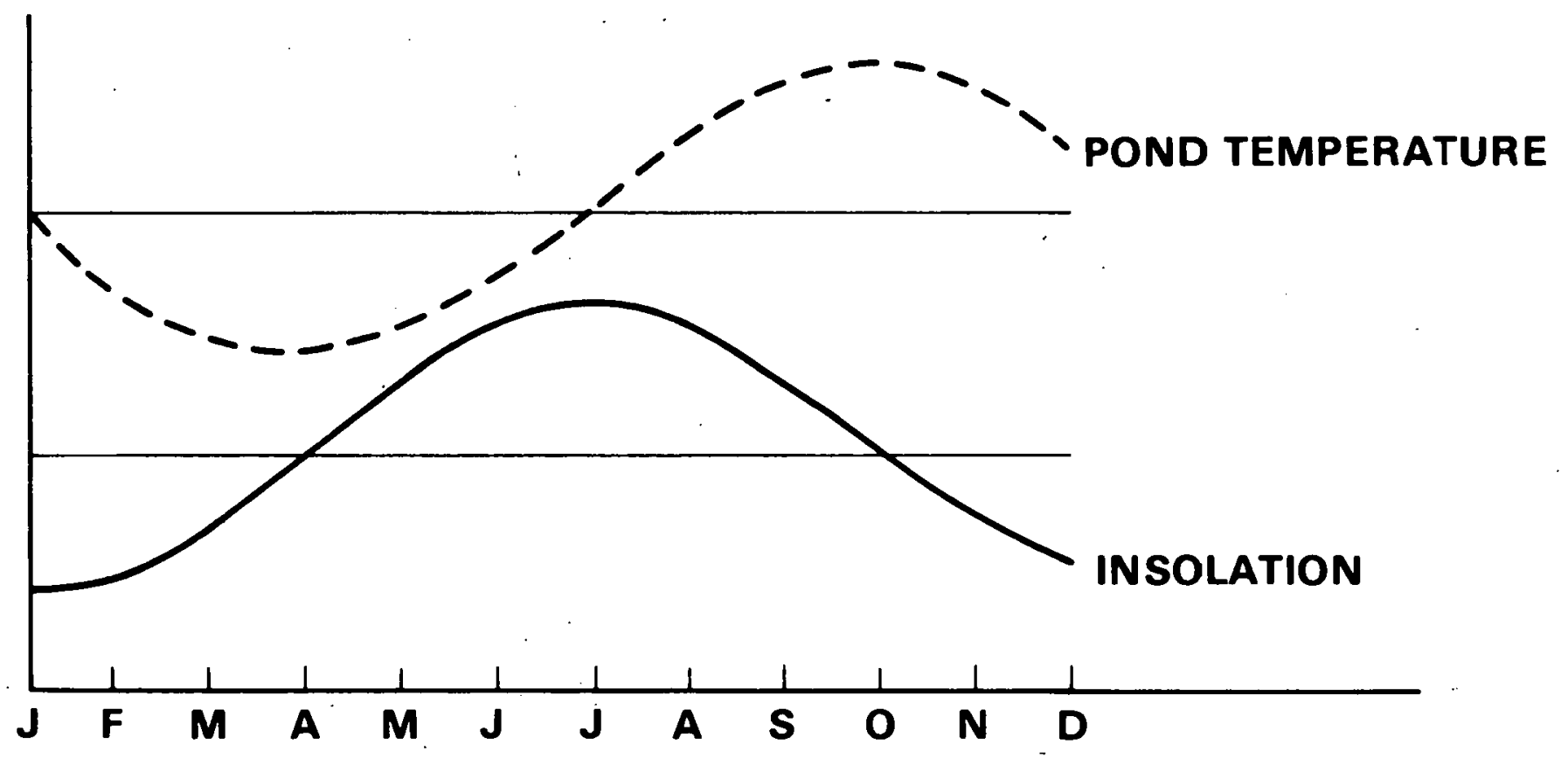

FIGURE 3.5. Phase Relationship Between Pond Temperature and Insolation 
layer, only perturbing the insulating layer by thermal energy exchanges through the membrane. Since similar thermal interactions exist between convection and insulating layers in conventional nonconvecting ponds, the primary difference between these two pond concepts is in the mechanical coupling and molecular diffusion rates between the two layers.

Instabilities associated with the insulating layer are identical to those in the insulating layer of the conventional pond. That is to say convection cells can occur at almost any depth and once initiated they may spread unless precautions are taken to quench them. The injection techniques developed and being tested by Nielsen show promise of this control.

It is important to note that effects of membrane partitions have not been evaluated extensively enough to draw precise conclusions of their value in controlling stability. The Russian experiments (Usmanov, et al.) (24) indicated membranes increased pond efficiency, even though the experimental ponds used were small and side effects may have been.considerable. On the other hand, these same investigators conclude from results of experiments on ponds without membranes that the bottom layer can be extracted and reinjected without loss of pond stability. If this can be shown on a much larger scale there will be no need for a partition to help assure stable operations. Indeed, Nielsen's extraction and injection experiments on an outdoor $\mathrm{NaCl}$ pond indicate this might be so. It should be realized, however, that the approximate temperature variation between surface and bottom was from 20 to $60^{\circ} \mathrm{C}$ in Nielsen's work. Ponds with larger temperature gradients may show instabilities not present with the smaller gradient.

\subsubsection{Operation}

Pond operation can be described in terms of the same properties which describe conventional nonconvective ponds. These properties have been designated previously as salt gradient preservation, transparency maintenance and energy extraction; their relationships to pond operation are discussed in the following pages. 


\subsubsection{Pond Transparency}

Maintenance of pond transparency is as critical to the membrane pond as it is to the conventional pond. Layer extraction and filtering might be used to remove suspended debris but removal of debris and algae accumulation on the partition could be difficult if adhesive forces at the surface of the partition prevent fluid flow from sweeping the membrane surface clean.

\subsubsection{Energy Extraction}

Membrane ponds look most attractive in the area of thermal energy extraction. This is because fresh water might be used in the convecting region below the membrane; as noted earlier in this report, this should be possible if the convecting region is pressurized to eliminate loading of the membrane. The corrosion problems associated with handling hot brine in the thermal energy exchangers would be eliminated then. In addition pond costs would decrease by about $50 \%$ since salt (the most costly ingredient in the pond) would not be used to build up the density of the nonconvective region.

It should be noted also that rate of extraction of the hot fluid is less dependent on stability of the insulating region than in the conventional pond where the convective (mixed) region thickness depends on rate of removal of the hot layer.

Conversion to electrical power will be similar to that envisioned for conventional nonconvecting ponds; i.e, thermal energy removed from the hot layer and converted to electrical energy by means of a closed or open cycle.

\subsection{Viscosity Stabilized Pond}

The use of thickeners to stabilize a solar pond is a relatively new concept. Analysis has been completed only on a preliminary basis. The discussion below was provided by L. H. Shaffer.

Little information is available on the spectral transmission characteristics of thickened solutions. It is expected that light transmission will be within 1 or $2 \%$ of that for clear water. However, the collection or development of real data is required. 
The question of viscosity versus convection is an exceedingly complex problem. In a nonconvecting system with a linear temperature/depth characteristic, the fourth power of the maximum stable depth should be directly proportional to the viscosity and inversely proportional to the $\Delta \mathrm{T}$.

Ponds that are $1 \mathrm{~m}$ deep, with bottom temperatures of 60 to $90^{\circ} \mathrm{C}$, can have viscosities as high as $100,000 \mathrm{cps}$ (about like mayonnaise - will not flow readily) and still not guarantee stability. Smaller temperature gradients, a shallower pond, lower temperatures, or perhaps other measures may be necessary. In connection with the viscosities, there is one favorable factor. All of the numbers reported herein and most that are available are for a flowing system; however, polymer gels are shear sensitive, and generally the zero shear rate viscosity--the one that applies before convection begins--is several times higher than the value appropriate to a flowing fluid.

In a working pond, it may be desirable to reduce the water loss associated with evaporation. It may be desirable to use a horizontal transparent cover on the pond.

\subsubsection{Thickeners for Viscosity Stabilized Solar Pond}

\section{Natural Polymers}

A truly astonishing number of natural polymers are available. which might be used to thicken water. Substances such as gum arabic, locust bean gum, algin, starch, and gelatin are all potentially useful for the purpose if sufficiently refined and clarified. The possible utility of these natural materials has not been pursued in any systematic manner for the following reasons: 1), the supplies of such materials are uncertain, 2) it would be hard to guarantee the cleanliness and quality control required for the routine preparation of clear gels from natural materials, and 3) materials such as starch and the starch derivatives and animal products such as casein and gelatin, are not expected to have the required degree of stability in hot aqueous systems. However, it seems likely that natural products such as the plant gums and seaweed extracts should be examined when time permits. 


\section{Semisynthetic Polymers}

In addition to the natural products that are normally water soluble (dispersible), there are a large number of materials based on cellutose. Cellulose itsclf is insolublc, but. soluble derivalives with a side variety of characteristics are easily prepared. The monomer unit of the cellulose chain may be taken to be glucose minus one molecule of water. There are three reactive $\mathrm{OH}$ groups per anhydroglucose residue. Variation in the number and kind of substituents allows great control over the properties of the derived polymer.

The water soluble derivatives of cellulose are manufactured in large quantity. They are intended to compete with, or replace, the natural gums and thickeners. They are inexpensive, of good quality, and seem inherently more stable than starch (both starch and cellulose are polysaccharides but they are linked together in a slightly different spatial arrangement). The principal water soluble cellulose derivatives are: carboxymethylcellulose, hydroxyethl cellulose, methylcellulose, and hydroxypropyl methylcellulose. Prices range from mostly $\$ 1.00$ to $\$ 1.20 / 1 \mathrm{~b}$ to a high of $\$ 1.60 / 1 \mathrm{~b}$. The cellulose derivatives are efficient thickeners: substantial effects are produced at concentrations of 1 to $3 \%$.

\section{Synthetic Polymers}

The synthetic polymers which seem most likely to produce substantial effects when used alone or as salts in aqueous systems are: polyacrylic acid (salts), polyacrylamide, a carboxy vinyl polymer, and polymers of ethylene oxide. Prices here range from $\$ 1.25$ to $\$ 2.90 / 1 \mathrm{~b}$, the most expensive being exceedingly efficient at only $1 \%$ in water.

In addition to the materials which provide a high degree of thickening by themselves, two water soluble synthetics offer outstanding possibilities for enhancing the performance obtained from other water soluble polymers. They are polyvinyl alcohol (PVA) and polyvinylpyrolidone (PVP). Consideration of blends and mixtures is far beyond the scope of the present report, 
but PVA at $\$ 0.57 / 1 \mathrm{~b}$, which its known excellent stability in hot aqueous solutions, and its superior resistance to sunlight, is certainly a prime candidate for inclusion in any further investigation.

\section{Special Techniques}

Cross-linked Polymer Gels. Several of the polymers already mentioned can be cross-1 inked to form permanent gels: 1) $0.5 \%$ solutions of CMC can be converted to soft gels by adding only $0.035 \%$ of basic aluminum acetate to the resin/water mixture; 2) the American Cyanamid Company has developed a "chemical grout" that is prepared by adding cross-linking agents and a catalyst to aqueous solutions of the polyacrylamides; and 3) materials such as PVP can be permanently gelled by heating the aqueous solution with alka1i. Techniques such as these offer great potential for reducing the cost of the polymer gel controlled solar pond. However, to get good light transmission we need a highly homogeneous mixture, and it is clear from the manufacturer's instructions that great care must be exercised to obtain a uniform gel. Research and development may be needed to learn how to make these gels reliably on a large scale. Further, some method for disposing of the "permanent" gels will eventually be needed.

Detergent/0il/Water Gels. It is possible to make clear gel-like compositions without using polymers at all. Quite a variety of ethylene oxide adducts of oil soluble organics will, either by themselves or with a clear oil in the system, form clear gels. The problem here is that most systems require a minimum of $20 \%$ of the organic ethoxylate at prices in the range of $\$ 0.50$ to $\$ 1.00 / 1 \mathrm{~b}$. This appears unattractive from an economir point of view. Perhaps there would be other benefits.

\subsubsection{Suitability of Various Polymers for Prolonged Use in Hot Water}

The semisynthetic (cellulosic) polymers may be heated in water to near the boiling point without obvious viscosity degradation, but they may not have long-term stability at temperatures above $60^{\circ} \mathrm{C}$. Methocel gels come out of solution at this temperature or a bit above depending on the grade. This phenomenon may serve to protect the polymer. At the same time, 
the precipitation of polymer will probably cause a drastic reduction in light transmission. This may provide a desirable degree of self-regulation.

Some of the synthetic polymers, polyacrylamide for example, may be just as limited as the cellulosics. However, substances such as PVA and carboxy vinyl polymer are expected to have outstanding stability in aqueous solution. The polymers of ethylene oxide precipitate reversibly from aqueous solutions just below the boiling point. They are expected to have adequate stability.

\subsubsection{Stabilization/Additives}

\section{Preservatives}

Any warm moist body offers the potential for the incubation of molds and bacteria and it seems likely that the upper cooler layers of the solar pond will require some defense. This is particularly important for the cellulosic materials as they are subject to enzymatic degradation. A great variety of suitable materials are known and the quantities needed are exceedingly small. For the preparation of cost estimates, we should add 1 to $2 \%$ to the value of the polymer.

\section{Antioxidants}

Many polymer degradation reactions involve oxygen, alkali, and possibly light. It is desirable to exclude oxygen and some pond designs will incidentally perform this function. Nevertheless, it is probably wise to plan for an oxygen scavenger. Inexpensive materials are available and they will be used in small quantities in any case. The cost will probably be negligible.

\section{Sunscreens}

Most organic materials are susceptible in one way or another to attack and degradation by ultraviolet light. For long-term stability under the conditions that will exist in the solar pond, materials that cut out or absorb the UV component of sunlight will almost certainly have to be added. Energy will not necessarily be lost; much of it may show up as heat in the upper layers of the pond. Compounds that are suitable for the 
protection of standard plastics are commercially available. For cost estimating, 1 to $2 \%$ should probably be added to the value of the polymer.

\subsubsection{Light Transmission and Physical Characteristics of Solution}

\section{Clarity}

Some of the polymers proposed are promoted on the basis of the exceptional clarity of the solutions or gels that they produce. However, there do not seem to be any precise data on the light transmission of long columns of the thickened fluids. Such data are needed, preferably at several different wavelengths. In the absence of any other information, solutions which look clear, water white, and which have been properly mixed so that there are no obvious strings or cords should be assumed to have the same light transmission characteristics as water.

\section{Physical Properties}

Dilute $(2 \%)$ solutions of the polymeric thickeners covered here will not differ appreciably from water in many physical properties. The refractive index may be increased by as much as $1 \%$, Densities should be within $0.3 \%$ of the value for the solvent, and for estimating purposes, the heat capacities may be taken to be the same as water. 


\subsection{PRELIMINARY DESIGN}

Comparative evaluation of the various solar pond concepts is accomplished by normalizing all concepts to the same set of operating and environmental conditions. The primary basis for comparison is a $10 \mathrm{MW}_{\mathrm{e}}$ gross output. A common gross power output was selected to facilitate use of Battelle-Northwest's computer codes available for power plants.

The baseline solar pond power system was delineated on the basis of technical feasibility where possible (i.e., systems and equipment with proven performance in other applications). The systems and equipment chosen are not necessarily the most economically viable. Innovations, situations of opportunity, or technological improvements that could substantially improve performance or reduce costs are discussed in Section 8.0.

Modern central power plants do not operate over the range of fluid temperatures available from solar ponds. Thus, standard equipment with highly predictable performance such as turbines and condensers are generally not applicable. The only power plant that could be found worldwide that operates over a similar range of fluid temperatures is the Paratunka Geothermal Electric Power Station on the Kamchatka Peninsula in Russia. (38) The plant operates on a binary fluid (Freon-12) Rankine cycle. Pertinent details of this plant are outlined below:

- Installed capacity - 750-1,000 kW (approximately $1 \mathrm{MW}_{\mathrm{e}}$ )

- Consumption of electric energy by power station - $37 \%$

- Cost of $1 \mathrm{~kW}$ installed capacity - 1600 rubles (1967) approximately $\$ 1600$ U.S. (1967)

- Geothermal water temperature - approximately $83^{\circ} \mathrm{C}\left(181^{\circ} \mathrm{F}\right)$

- Geothermal water flow rate - 1272 gpm (approximately 17,000 gpm for $10 \mathrm{MW}_{\mathrm{e}}$ )

- Cooling water temperature $-15^{\circ} \mathrm{C}\left(59^{\circ} \mathrm{F}\right)$

- Cooling water flow rate - $6693 \mathrm{gpm}$ (90,000 gpm for $\left.10 \mathrm{MW}_{\mathrm{e}}\right)$

- $\Delta \mathrm{T}$ between source and sink $-68^{\circ} \mathrm{C}\left(122^{\circ} \mathrm{F}\right)$. 
A single annual average value (550 1y/day $-0.26 \mathrm{~kW} / \mathrm{m}^{2}$ ) for insolation was selected. The limited time available precluded evaluation over a range of daily and seasonal environmental fluctuations. Similarly, climatological factors such as temperature and humidity were represented by single representative values, although such values were not necessarily mean annual averages.

The following assumptions or ground rules were selected:

- The power plant has a gross output of $10 \mathrm{MW}_{\mathrm{e}}$.

- The baseline power plant is a binary fluid (isobutane) closed Rankine cycle using conventional tube-and-shell heat exchangers. A flashed steam cycle is included for comparative purposes.

- Storage of heat in the ground beneath the pond or removal of heat by groundwater are neglected with respect to power production. This is a conservative assumption, since ground heat will in fact contribute to smoothing out pond temperatures.

- All cooling water is provided by wet cooling towers.

- Evaporation rates are based on a relative humidity of $40 \%$ and dry bulb temperature of $21^{\circ} \mathrm{C}\left(70^{\circ} \mathrm{F}\right)$.

- The salt concentration is $25 \mathrm{wt} \%$ and the salt used is magnesium chloride. (Note: $0.25 \mathrm{~g} / \mathrm{cm}^{3}$ was used in thermodynamic calculations).

- Land costs $\$ 500 /$ acre with utilities, access roads, and improvements.

- All ponds are lined on the sides and bottom to prevent leakage, but not insulated.

- Wave suppressors are required in open ponds.

- The useful life of the pond and power plant is 30 years.

The cost analysis is directed toward two basic items: 1) capital cost in $\$ / \mathrm{kW}$ using 1975 dollars and no escalation and 2) energy cost at the bus bar at a wholesale price in mills/kW-hr. The capital cost is divided into direct and indirect costs. Direct costs include equipment purchases, 
construction and installation costs. Indirect costs include interest on capital money, taxes, insurance, engineering costs, quality assurance, etc. The energy cost is calculated from the total capital cost by summing fixed charges (insurance, interest, taxes, etc.) and operation and maintenance (O\&M) costs (personnel charges plus annual expendables).

\subsection{Preliminary Design of Ponds}

For comparison purposes, it is assumed that, except for the shallow pond, the pond characteristics are similar. Since there are no completely reliable engineering design data on any of the systems, this seems a reasonable assumption.

Each nonconvecting pond is assumed to be $6 \mathrm{ft}(1.83 \mathrm{~m})$ deep. All of the ponds are assumed to operate at $90^{\circ} \mathrm{C}\left(194^{\circ} \mathrm{F}\right)$. Such an operating temperature throughout the year may be optimistic. If this temperature is maintained during periods of low insolation the energy extraction rate will have to be lowered. This would have the effect of increasing power costs. However, effects will be comparable for each of the pond types. Hence, for comparative purposes, this is considered an adequate assumption.

For reference design purposes, an overall cycle efficiency of $2-1 / 2 \%$ (electrical energy at bus bar versus mean solar insolation) was assumed. Pond costs were to be adjusted proportionally for variation from this. However, cycle efficiencies obtained in subsequent analyses were close enough to this value that. the estimated pond costs were used with little modification.

\subsubsection{Pond Size}

An average annual insolation of $550 \mathrm{ly} /$ day is used for pond sizing.

$$
\begin{aligned}
& 550 \mathrm{cal} / \mathrm{cm}^{2}-\text { day }= \\
& 550 \mathrm{cal} / \mathrm{cm}^{2}-\text { day } \times 929 \mathrm{~cm}^{2} / \mathrm{ft} \\
& \times 1 / 252 \mathrm{Btu} / \mathrm{cal}=2028 \mathrm{Btu} / \mathrm{ft}^{2}-\text { day } \\
&=2028 \mathrm{Btu} / \mathrm{ft}^{2}-\text { day } \times 365 \text { days } / \mathrm{yr} \\
&=740,220 \mathrm{Btu} / \mathrm{ft}^{2}-\mathrm{yr}
\end{aligned}
$$


At $550 / 1 y$ day and $2-1 / 2 \%$ overall efficiency 10 . MW requires a pond size of:

$\frac{10 \mathrm{MW}_{\mathrm{e}}}{0.025}=400 \mathrm{MW}$ thermal

$400 \mathrm{MW} \times 365$ days $/ \mathrm{yr} \times 24 \mathrm{hr} /$ day

$=3.5 \times 10^{9} \mathrm{~kW}-\mathrm{hr} / \mathrm{yr}$

$1 \mathrm{~kW}-\mathrm{hr}=3412 \mathrm{Btu}$

$3.5 \times 10^{9} \times 3412=1.2 \times 10^{13} \mathrm{Btu} / \mathrm{yr}$

$\frac{1.2 \times 10^{13} \mathrm{Btu}}{740,220 \mathrm{Btu} / \mathrm{ft}^{2} \mathrm{yr}}=1.6 \times 10^{7} \mathrm{ft}^{2}$

$=4000 \mathrm{ft}(1.22 \mathrm{~m})$ on a side

\subsubsection{Common Pond Chararacteristics}

The common design characteristics of each nonconvecting pond follow.

\section{Earth Construction}

The pond is constructed on nearly level ground which requires only a few passes with a patrol grader for leveling. The dike is constructed by moving earth from directly outside the pond area, creating a shallow ditch. The dike is $12 \mathrm{ft}$ across at the top to provide a reasonable access road. Dike construction is illustrated in Figure 4.1 .

\section{Pond Lining}

The pond is lined with hypalon. While extensive work might indicate that a clay lining or building ponds on clay might be adequate, the relatively small cost and the extra degree of environmental protection achieved with a liner indicate this to be a worthwhile step. The hypalon liner also provides a uniformly black surface and protects against plant growth from the bottom of the pond. There is a reasonable amount of experience with lined ash ponds and other large-scale applications. The material can be guaranteed for 20 years.

The bottom liner (and membranes where used) are retained with a 12 in. wide by $24 \mathrm{in}$. deep concrete section running the full circumference of the pond. 


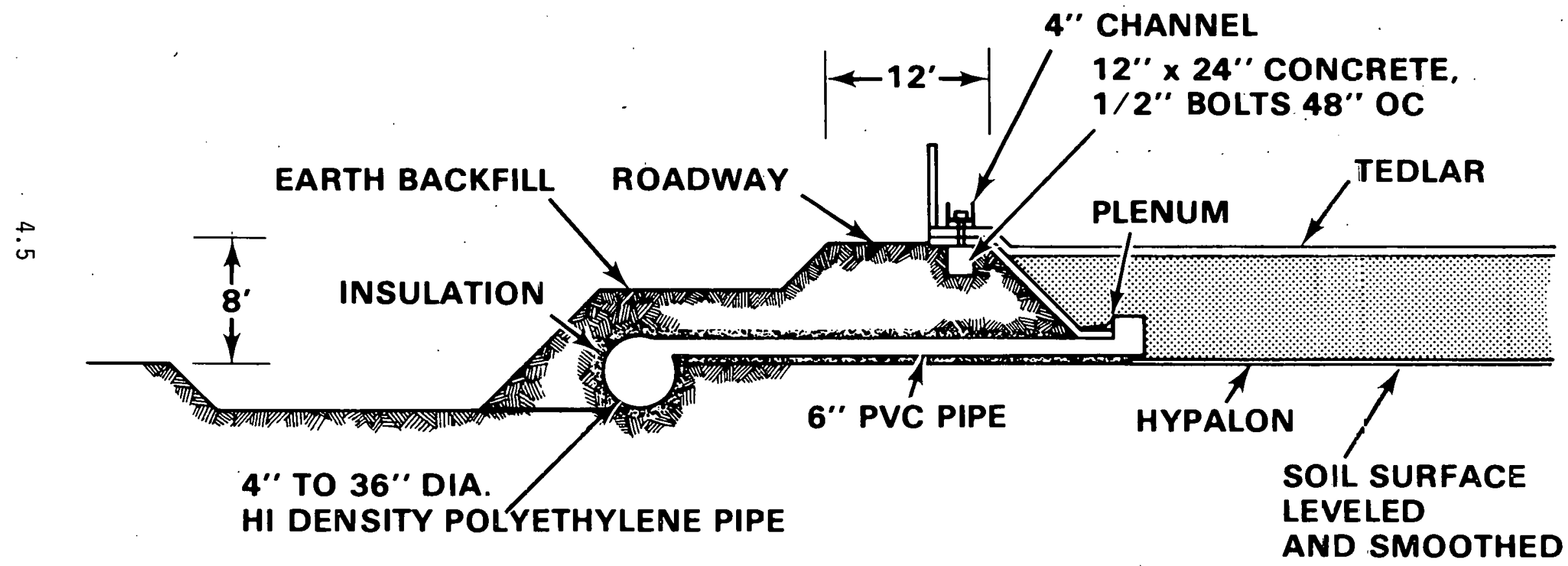




\section{Heat Extraction}

For design purposes, it is assumed that a layered flow can be achieved without introducing pond instabilities. Flow is calculated as follows for the reference pond. As with pond size, variations arrived at from power plant design were to be adjusted proportionally. However, the effects were small enough and time short enough that these iterations were not made. The design arrived at below was used for cost purposes.

Assume:

$$
\begin{aligned}
& \text { Power }=10 \mathrm{MW} \\
& \text { Insolation }=550 \mathrm{cal} / \mathrm{cm}^{2} \text { day average over year } \\
& \Delta T=14.5^{\circ} \mathrm{C}\left(26^{\circ} \mathrm{F}\right) \\
& \ell=10 \% \text { cycle efficiency } \\
& \rho=\text { density }=1.2 \mathrm{~g} / \mathrm{cm}^{3} \\
& \mathrm{Cp}=\text { heat capacity }=0.86 \mathrm{cal} / \mathrm{g}^{\circ} \mathrm{C} \\
& \mathrm{F}=\mathrm{flow}, \mathrm{ft}^{3} / \mathrm{min}\left(28,316 \mathrm{~cm}^{3} / \mathrm{ft}^{3}\right) \\
& 1 \text { watt }=14.3 \mathrm{cal} / \mathrm{min}
\end{aligned}
$$

Then:

$$
\begin{aligned}
& \text { Power }= 10 \mathrm{MW}_{\mathrm{e}} \times 10^{6} \frac{\mathrm{W}}{\mathrm{MW}} \times 14.3 \mathrm{cal} / \mathrm{min}-\text { watt } \\
&= 0.1 \times \mathrm{F} \times 1.2 \frac{\mathrm{g}}{\mathrm{cm}^{3}} \times 0.86 \mathrm{cal} / \mathrm{g}-{ }^{\circ} \mathrm{C} \\
& \times 14.5^{\circ} \mathrm{C} \\
& 1.43 \times 10^{8} \mathrm{cal} / \mathrm{min}=1.50 \mathrm{~F} \frac{\mathrm{cal}}{\mathrm{cm}^{3}} \\
& \text { Flow }=\mathrm{F}=0.95 \times 10^{8} \frac{\mathrm{cm}^{3}}{\mathrm{~min}^{\circ}} . \\
&= 3354 \mathrm{ft}^{3} / \mathrm{min} \\
&= 26,400 \mathrm{gpm}
\end{aligned}
$$

With a pond width of $4,000 \mathrm{ft}$ and a flow of $3300 \mathrm{ft}^{3} / \mathrm{min}$, the velocity of a $1 \mathrm{ft}$ thick layer would be: 


$$
\begin{aligned}
\text { Velocity } & =\frac{\text { volume } / \mathrm{min}}{\text { cross section }} \\
& =\frac{3,354 \mathrm{ft}^{3} / \mathrm{min}}{4,000 \mathrm{ft} \times 1 \mathrm{ft}} \\
& =0.82 \mathrm{ft} / \mathrm{min}(0.25 \mathrm{~m} / \mathrm{min})
\end{aligned}
$$

This velocity is sufficientiy low that layered flow seems a possibility.

With a heated layer only $1 \mathrm{ft}$ deep and a velocity of $0.82 \mathrm{ft} / \mathrm{min}$, it is interesting to note that the layer would be completely changed in $\frac{4000 \mathrm{ft}}{0.82 \mathrm{ft}} / \mathrm{min}$ $=4900 \mathrm{~min}$ or $\frac{4900 \mathrm{~min}}{60 \mathrm{~min} / \mathrm{hr}}=82 \mathrm{hr}$, or about $31 / 2$ days.

Assuming a $5^{\circ} \mathrm{C} \Delta \mathrm{T}$ is allowable for power plant operation, the time required to restore a meter of water from the lowest to the peak temperature (say from $87^{\circ} \mathrm{C}$ to $92^{\circ} \mathrm{C}$ ) is calculated below;

A $1 \mathrm{~m}$ deep by $1 \mathrm{~cm}^{2}$ column at $5^{\circ} \Delta \mathrm{T}$ requires $100 \mathrm{~cm}$ deep $\times 1 \mathrm{~cm}^{2}$ cross section $\times 5^{\circ} \Delta \mathrm{T} \times \mathrm{cal} / \mathrm{cm}^{3}-{ }^{\circ} \mathrm{C} \Delta \mathrm{T}=500 \mathrm{cal}$. With $500 \mathrm{cal} / \mathrm{cm}^{2}-$ day and an insolation efficiency of $25 \%$, the time required to recover is

$$
\begin{aligned}
\frac{500 \mathrm{cal} / \mathrm{cm}^{2}}{550 \mathrm{cal} / \mathrm{cm}^{2}} & - \text { day } \times 0.25 \text { efficiency } \\
& =3.64 \text { days }
\end{aligned}
$$

A slotted plenum for water removal is placed the full length of the pond and connected to transfer piping by a 6-in. diameter plastic pipe through the dike. A comparable system is installed on the opposite side of the pond for water addition (Figure 4.2).

While cost estimates were based on this design, subsequent thinking is that the collection and distribution pipes could be placed directly in the pond, eliminating the need for insulation and simplifying the constrution considerably. However, flows arrived at subsequently were actually considerably greater than those used for cost estimates, so the estimates were not changed. It is expected that this analysis will be revised in the future, but the total present estimate is only a little over $\$ 1,000,000$ so the modifications are not expected to be significant. 


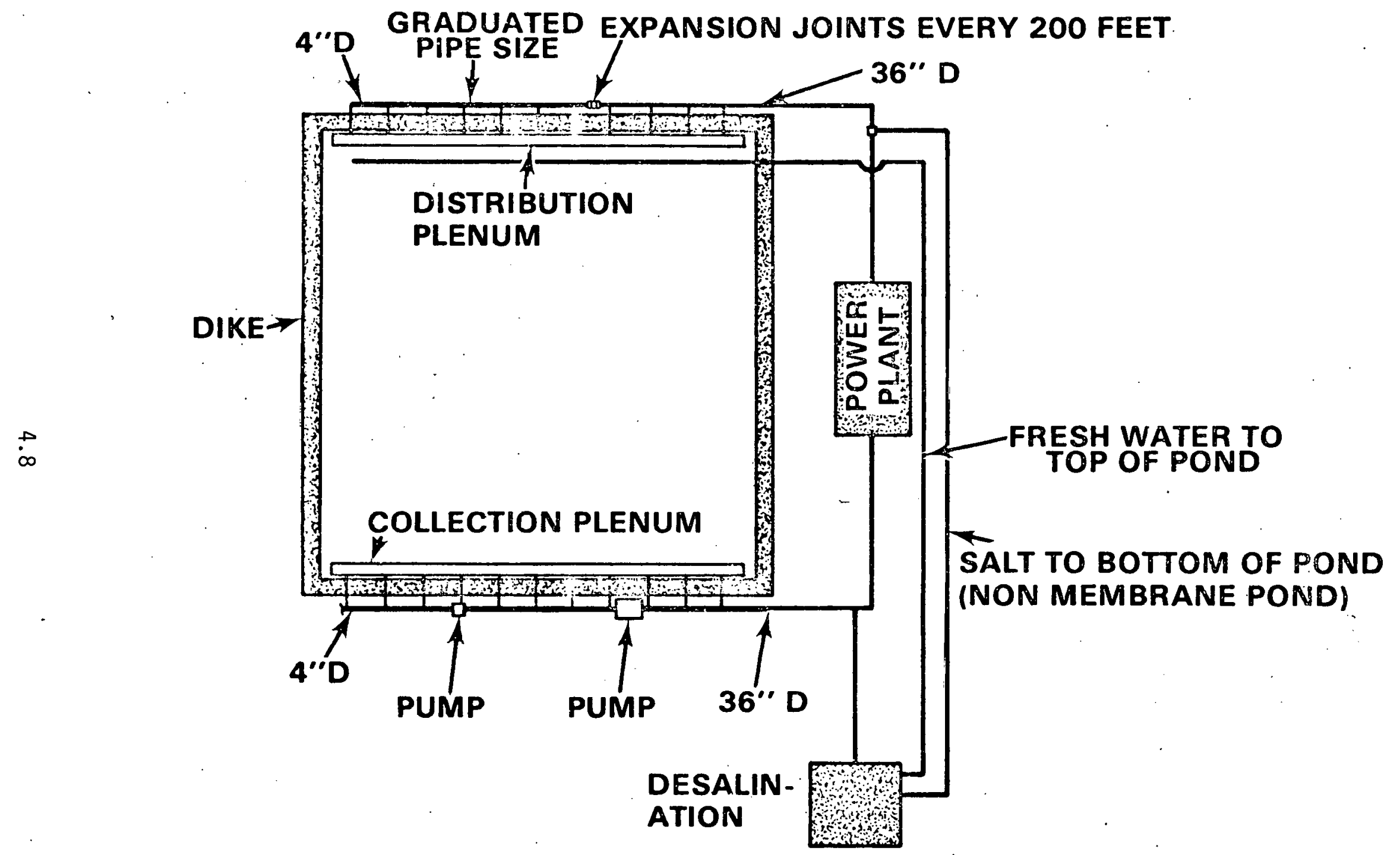

FIGURE 4.2. Plan View of Reference Nonconvecting Pond System 
Facilities for desalination and makeup materials shown in Figure 4.2 will be discussed later.

As an alternate, a separate item is identified for economic considerations. This assumes that laminar flnw arross the full width of the pond cannot reasonably be achieved. To compensate, 4 in. slotted pipes are placed every $100 \mathrm{ft}$ on both the inlet and outlet sides, the full width of the pond and water is transferred only $50 \mathrm{ft}$. The $4 \mathrm{in}$. pipes are placed as shown in Figure 4.3, so flow from incoming pipes travels only $50 \mathrm{ft}$ from each side to an exit pipe. Flow in opposite directions with such an arrangement could help to reduce overall drag on different pond layers. It should be noted that this is simply a concept and fairly extensive analysis and experimentation is required to provide design information suitable for actual pond construction. This alternate arrangement requires $50-4000 \mathrm{ft}$ lengths of 4 in. slotted pipe on each side, a total of $80 \times 4000=320,000 \mathrm{ft}$ of pipe.

The pipe from the plenum to the power plant is placed outside the dike and buried with cured-in-place insulation 6 in. thick. Expansion fittings are provided every $200 \mathrm{ft}$ (Figure 4.2). The pipe size is varied from 4 in. diameter at the far end to $36 \mathrm{in}$. diameter at the power plant. Pipe is sized for 8 fps maximum velocity and the size is increased in 500-ft increments to accommodate added flow along the length.

Using a flow rate of $3,300 \mathrm{ft}^{3} / \mathrm{min}$ and a maximum velocity of $8 \mathrm{ft} / \mathrm{sec}$, the pipe diameter at entry to the power system is:

$$
\begin{aligned}
F= & 3,300 \mathrm{ft}^{3} / \mathrm{min}= \\
& =\text { area of pipe } \times \text { velocity } \\
& =A \times 8 \mathrm{fps}=A \times 8 \mathrm{fps} \times 60 \mathrm{sec} / \mathrm{min} \\
& A=\frac{3,300 \mathrm{ft}^{3} / \mathrm{min}}{480 \mathrm{ft} / \mathrm{min}} \\
& =6.9 \mathrm{ft}^{2}=6.9 \times 144 \mathrm{in.}^{2} \\
& =1000 \mathrm{in} .
\end{aligned}
$$




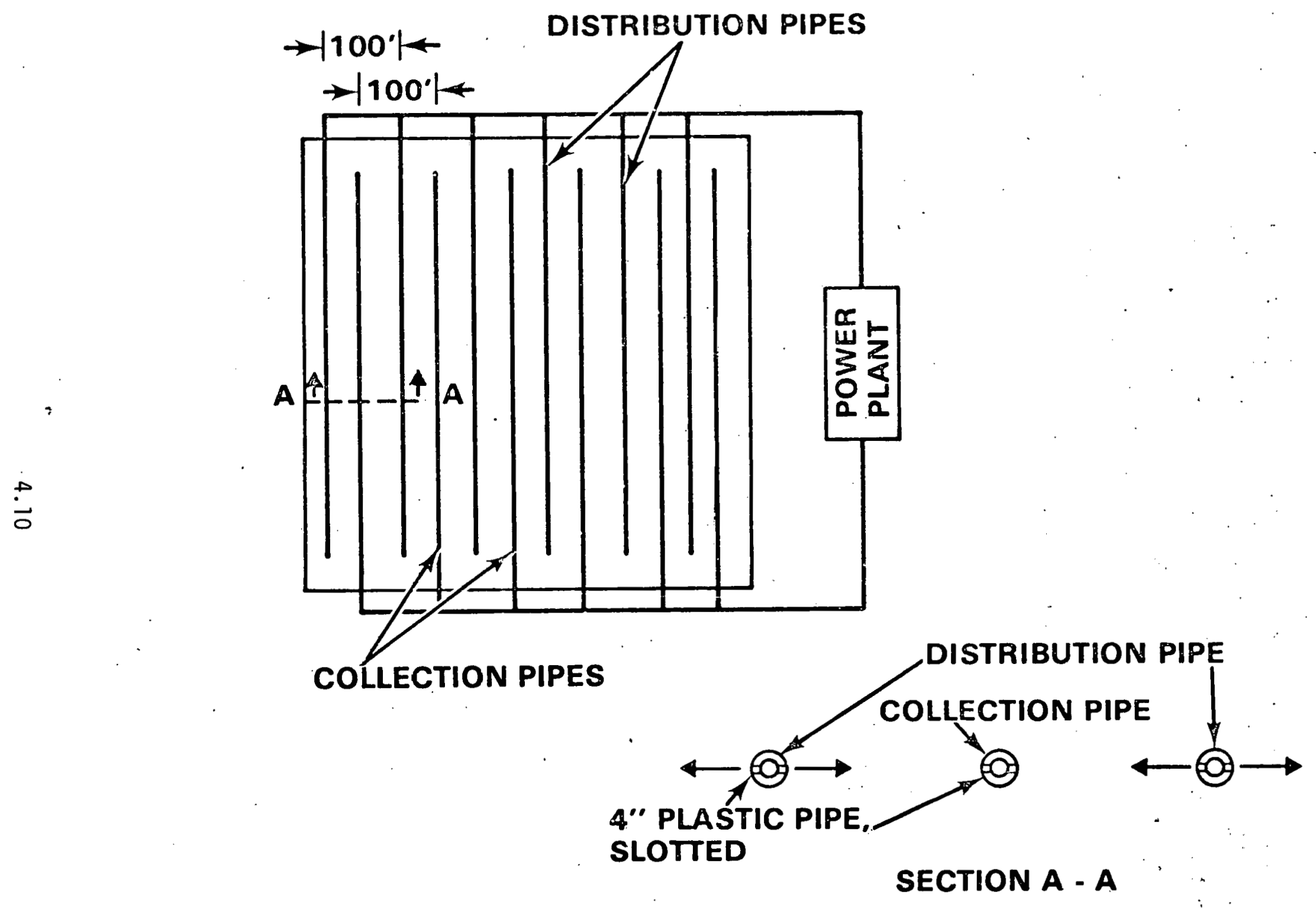

FIGURE 4.3. Alternate Layer Removal System 


$$
\begin{aligned}
& A=\frac{\pi D^{2}}{4} \\
& D^{2}=\frac{4 A}{\pi}=\frac{4 \cdot 1000}{\pi}=1270 \\
& D=\underline{\underline{35.6}} \mathrm{in.}
\end{aligned}
$$

Using a pipe length of $4000 \mathrm{ft}, 500 \mathrm{ft}$ increments and a minimum pipe diameter of 4 in., the pipe sizes would be:

$\begin{array}{ccc} & \text { Area, in. } & \\ 1 & 1000 & \text { Pipe, I.D. in. } \\ 2 & 859 & 36 \\ 3 & 718 & 33 \\ 4 & 577 & 30 \\ 5 & 436 & 27 \\ 6 & 295 & 24 \\ 7 & 154 & 20 \\ 8 & 13 & 14 \\ & 13 & 4\end{array}$

Subsequent analysis showed larger flow to be desirable to optimize heat exchanger $\Delta \mathrm{T}$. However, an iteration in pipe size was not made.

Pumping stations are placed $1500 \mathrm{ft}$ and $3000 \mathrm{ft}$ from the power house end of the pond outlet pipe.

Pump sizes will. vary with power plant characteristics.

Reference pond characteristics specific to pond type are discussed below.

\subsubsection{Nonconvecting Salt Pond}

A cross section of the nonconvecting salt pond is shown in Figure 4.4. It is assumed that the bottom foot of the pond is uniformly $25 \mathrm{wt} \% \mathrm{MgCl}$. The top $5 \mathrm{ft}$ of the pond varies uniformly from $25 \mathrm{wt} \%$ to $0 \mathrm{wt} \% \mathrm{MgCl}$. $\mathrm{MgCl}$ is used for reference purposes because it is presently believed to offer greater stability potential. $\mathrm{NaCl}$ or other materials may be less expensive and may ultimately be shown to be satisfactory. 


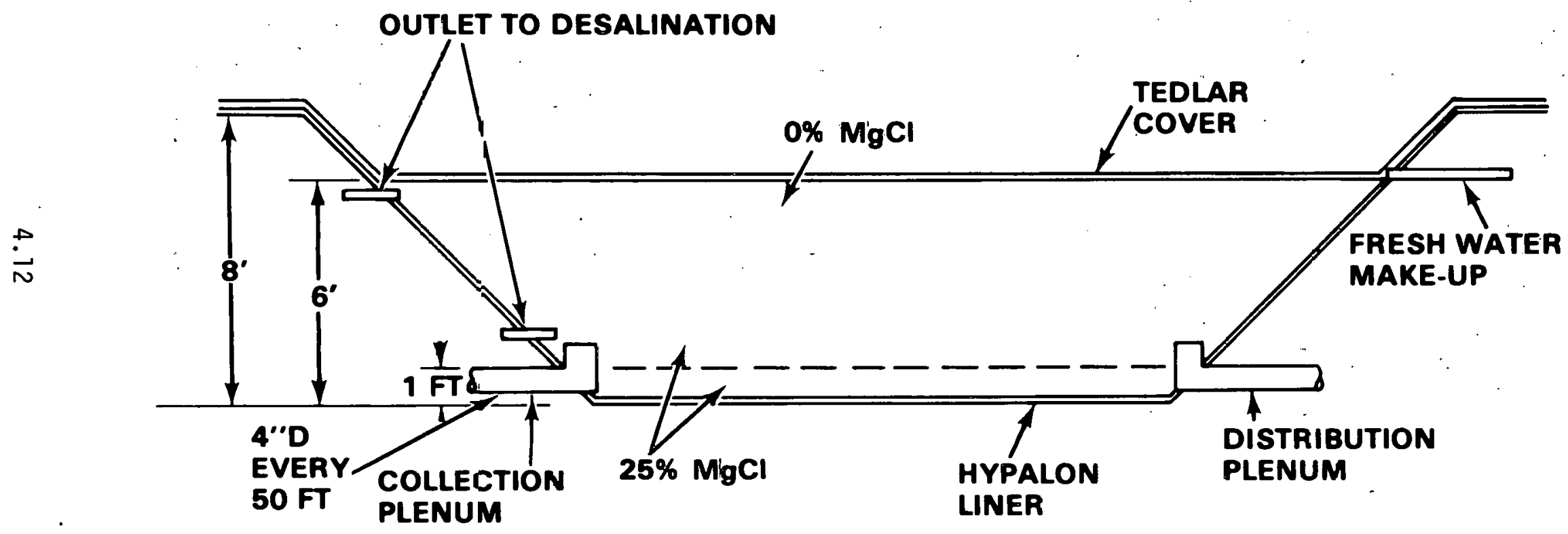

FIGURE 4.4. Nonconvecting Salt Pond Cross Section 
The density gradient is maintained with recycled salt and fresh water from either a flash evaporation cycle or from distillation of a part of the pond outlet stream (Figure 4.3).

At $0.063 \mathrm{~kg} / \mathrm{m}^{2}$-day diffusion rate, a pond $4000 \mathrm{ft} \times 4000 \mathrm{ft}$ will require:

$$
\begin{aligned}
& 16 \times 10^{6} \mathrm{ft}^{2} \times 0.09 \mathrm{~m}^{2} / \mathrm{ft}^{2} \\
= & 14.4 \times 10^{5} \mathrm{~m}^{2} \\
& 0.63 \mathrm{~kg} / \mathrm{m}^{2}-\text { day } \times 14.4 \times 10^{5} \mathrm{~m}^{2} \\
= & 9.1 \times 10^{4} \mathrm{~kg} / \text { day } \\
= & 9.1 \times 10^{4} \times 2.2 \mathrm{lb} / \text { day } \\
= & 200,000 \mathrm{lb} / \text { day }
\end{aligned}
$$

At $25 \mathrm{wt} \%$ salt, the weight of water to be evaporated each day is thus:

$$
\begin{aligned}
& 200,000 \times 3 \\
& 600,000 \mathrm{lb} / \text { day } \\
& \text { or } \frac{600,000}{8 \mathrm{lb} / \mathrm{ga}]}=75,000 \mathrm{gal} / \text { day }
\end{aligned}
$$

For desalination, a vapor compression cycle system was used for estimating purposes because a budget-type estimate could be obtained from a manufacturer ${ }^{(39)}$ very quickly. For the 75,000 gal/day requirement, the estimated cost was $\$ 500,000$. The vapor compression cycle system requires power to operate - about $3 \%$ of the plant output. This has not been included separately in parasitic power loss calculations, but is probably within the tolerance of the figures used for such losses.

Since we are using the sun and looking for electrical power, a solar still is probably more logical and should be given a detailed look in future considerations.

Makeup water to compensate for evaporation is also added with the desalinated water. 
The salt is injected into the pond inlet line (Figure 4.2) and uniformly mixed prior to reaching the inlet plenum. The fresh water is added at the top of the pond, along with the makeup water. The combination of supersaturated solution at the inlet at the bottom of the pond and fresh water flowing across the top of the pond will be designed to maintain the density gradient.

A Tedlar cover 4 mils thick is provided for this pond to reduce evaporation, minimize debris, and prevent wave action. The Tedlar cover is provided with air pockets for buoyancy.

\subsubsection{Nonconvecting Membrane Pond}

In the membrane pond (Figure 4.5), if membrane support were not provided the salt concentration would have to be the same as in the nonmembrane pond- $-25 \%$ in the bottom half and 25 to $0 \%$ in the top half. There would thus be little difference in the membrane pond and the nonmembrane pond. An extra 4-mil Tedlar sheet would be added and stability problems would be simplified. In practice, this pond might require more salt than a nonmembrane pond. In the latter some gradient might be possible from top to bottom. In the former, the bottom half would have to be heavier, or at equal pressure with the top half.

Thus, for comparison purposes, a water-tight membrane with sufficient strength to support the higher. density top half was considered.

The difference in weight of the top half, assuming a uniform gradient from $25 \%$ to $0 \%$ is :

$$
\begin{aligned}
\frac{30.4 \mathrm{in} . / \mathrm{m}}{12 \mathrm{in.} / \mathrm{ft}} & \times 1 \mathrm{ft}^{2} \times 62.5 \mathrm{ib} / \mathrm{ft}^{3} \\
& \times 0.25 \times 0.50 \\
& =25.6 \mathrm{lb} / \mathrm{ft}^{2}
\end{aligned}
$$

This is a greater loading than the minimum live load $\left(20 \mathrm{bb} / \mathrm{ft}^{2}\right)$ in the Uniform Building Code. To support such a load in a flowing salt solution appears at first glance to be unreasonably costly.

A simple design, shown in Figure 4.6, and cost estimate appear to support this conclusion. 


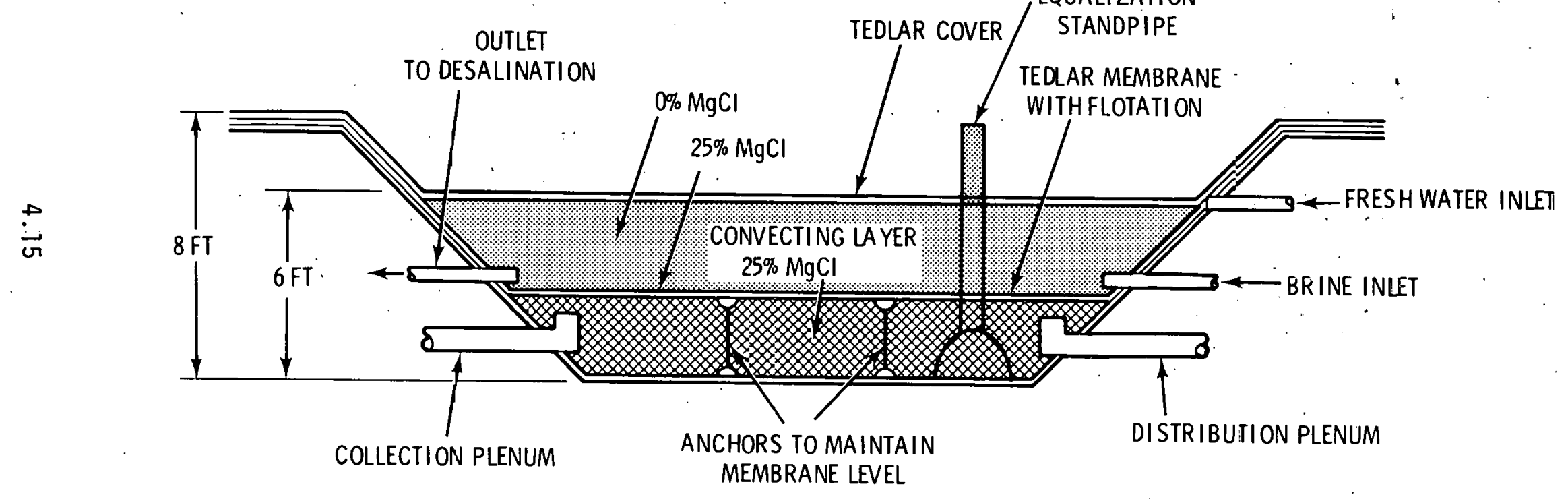

FIGURE 4.5. Cross Section Membrane Pond 


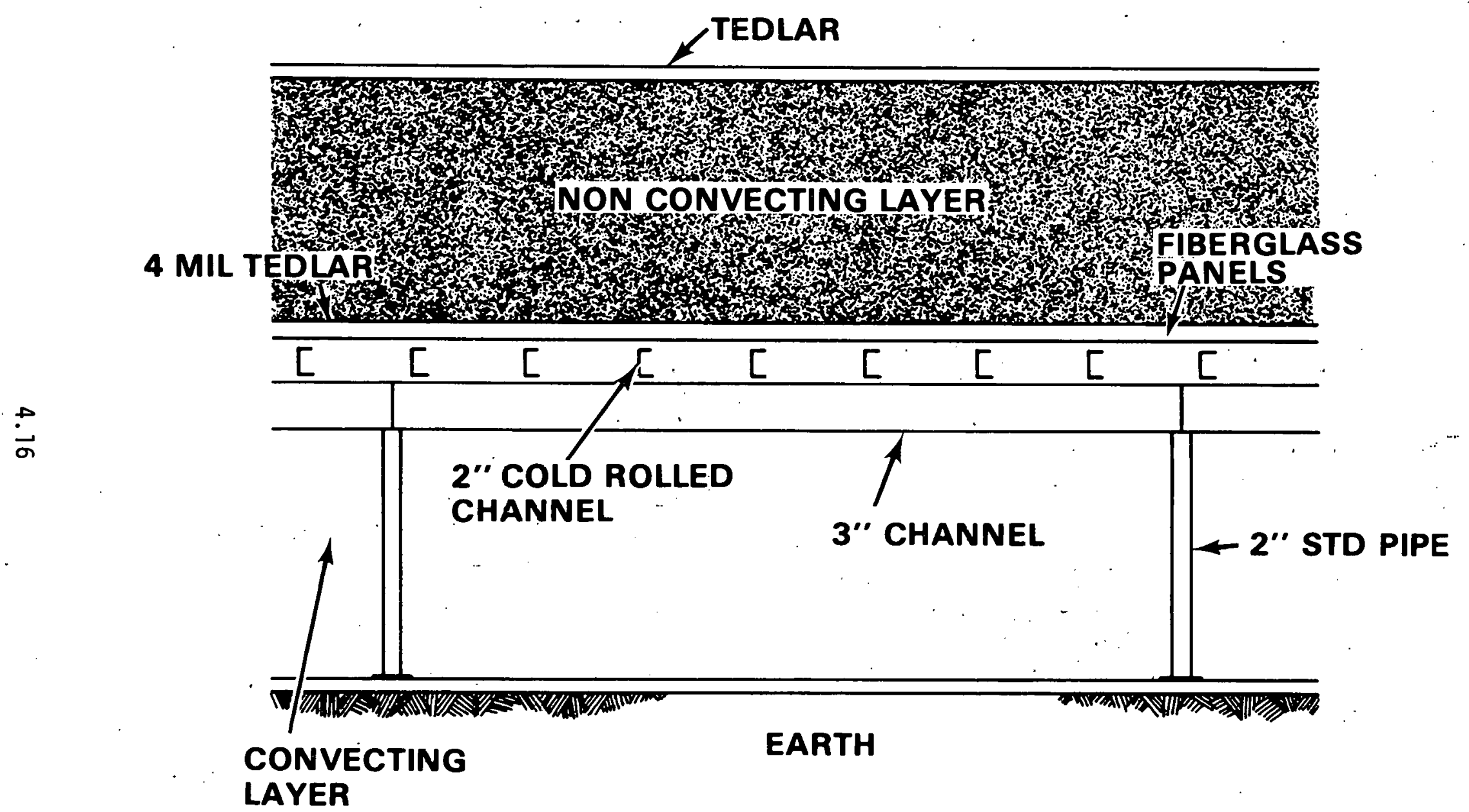

FIGURE 4.6. Membrane Support for Membrane Pond with Fresh Water Convecting Layer 
Because of the above problems, a concept based on a membrane with pressure equalized on each side was used. This concept is illustrated in Figure 4.5. By pressurizing the bottom half of the pond with one or more standpipes, pressure is the same on each side of the membrane and structural support is not required. The membrane should be leak-free. However, since the pressure is equal on each side, transfer from one side to another would be by diffusion and convection and not by a pressure difference. Maintaining a leak-free, or nearly so, membrane of a size in the range of $4,000 \mathrm{ft}$ on a side seems difficult. The use of a series of smaller ponds might be one approach to simplification of this problem.

In order to avoid discharging salt water outside of the pond environment and minimize salt costs, the reference pond withdraws from the bottom layer, just above the membrane, desalinizes this, and returns fresh water and salt to the pond. This is illustrated in Figure 4.5.

\subsubsection{Nonconvecting Gelled Pond}

Because of the relatively limited evaluation of gelled pond concepts, this type of pond is subject to more variation in approach. Thus, while the following reference design is specific, it should be noted that it may be even less firm than the previous design. However, the potential for success of gelled ponds appears to be at least as great or perhaps greater than that of salt ponds.

In order to minimize potential problems in pumping a high viscosity solution and to optimize pond stability, a pond depth of $6 \mathrm{ft}(1.83 \mathrm{~m})$ is assumed with the bottom $3 \mathrm{ft}$ being brine or water with sufficient salt content to assure that the gel will float. (See Figure 4.7.)

The top $3 \mathrm{ft}$ are water-gelled with a synthetic polymer.

A cover sheet of 4-mil Tedlar is used to minimize evaporation and debris. A 4-mil Tedlar sheet is als o placed between the top layer and bottom layer to prevent mixing. 


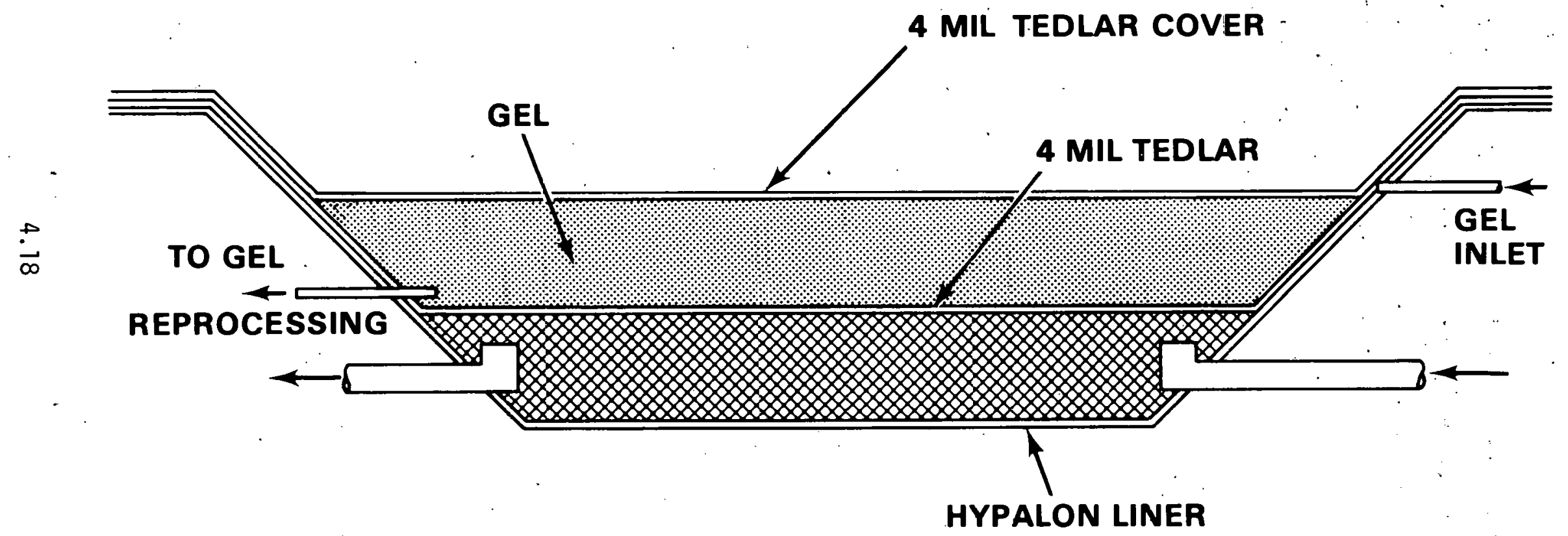

FIGURE 4.7. Cross Section of Gelled Pond 


\subsubsection{Shallow Convecting Pond}

For the shallow pond concept, design and cost data from a recent LLL report are used. (40) The collection temperature is assumed to be $90^{\circ} \mathrm{C}$ and the collection efficiency is assumer to be $25 \%$ of the avcrage annual insolation. LLL calculations $(40)$ actually indicate efficiencies of $32.9 \%$ to $59.7 \%$ with an annual average of $43.4 \%$. However, these are based on a temperature increase during the day with a final pond water temperature of $29^{\circ} \mathrm{C}\left(85^{\circ} \mathrm{F}\right)$ to $79^{\circ} \mathrm{C}\left(175^{\circ} \mathrm{F}\right)$. In practice, a power plant system would be deșigned to optimize the power plant efficiency - collector temperature - collector efficiency relationship.

The collector design is a single plastic glazing over a water bag. This design is illustrated in Figure 4.8.

In order to provide comparable storage, a volume equivalent to the nonconvecting ponds is used. This volume is provided in a reservoir $45 \mathrm{ft}(14 \mathrm{~m})$ deep with a surface area $1 / 7$ that of the nonconvecting ponds. This provides a liquid storage valume comparable to that of the convecting layer in the nonconvecting ponds. Storage from the earth is reduced. However, this is mintmal for the assumptions used. In practice, because we are working with a low $\Delta T$ and high flow rates, the storage in the earth is probably of little significance for short-term - hours or days - needs.

The earth is used as insulation for the sides and bottom of the pond. The top is insulated with a 6 in. layer of styrofoam floating on the surface and a 4-mil Tedlar cover to minimize evaporation and heat loss due to winds.

The storage tank is illustrated in Figure 4.9.

\subsection{Power Plant}

Calculations were based on two plant types, a binary fluid cycle using isobutane and a flash steam plant. A schematic of the binary fluid plant is shown in Figure 4.10, A flashed steam plant is shown in Figure 4.11. Conventional shell-and-tube heat exchangers, located outside 


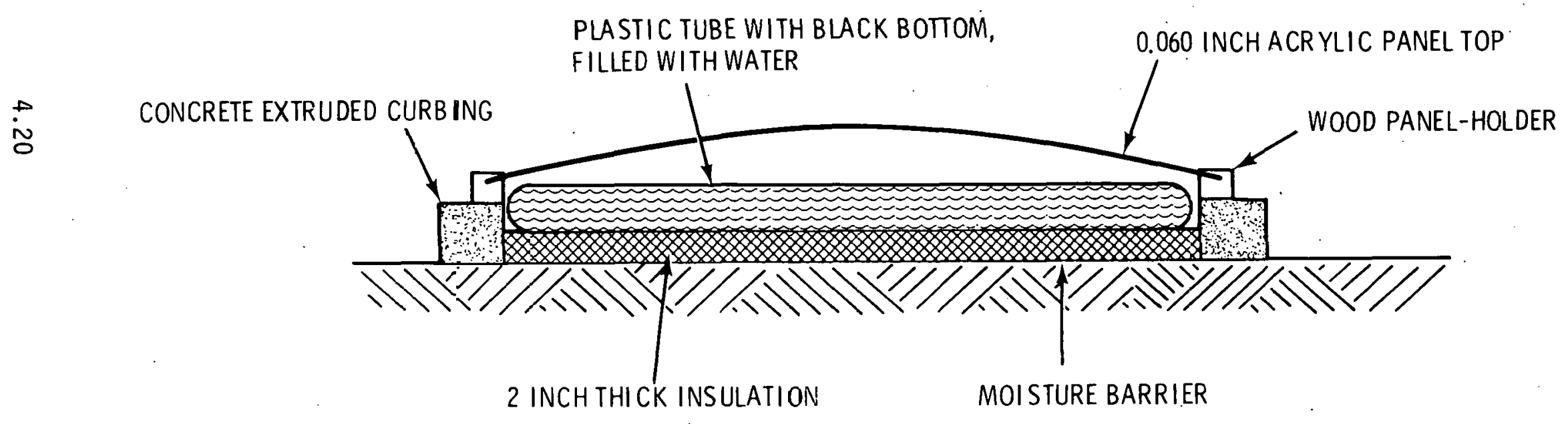

FIGURE 4.8. Shallow Solar Pond Concept by LLL 


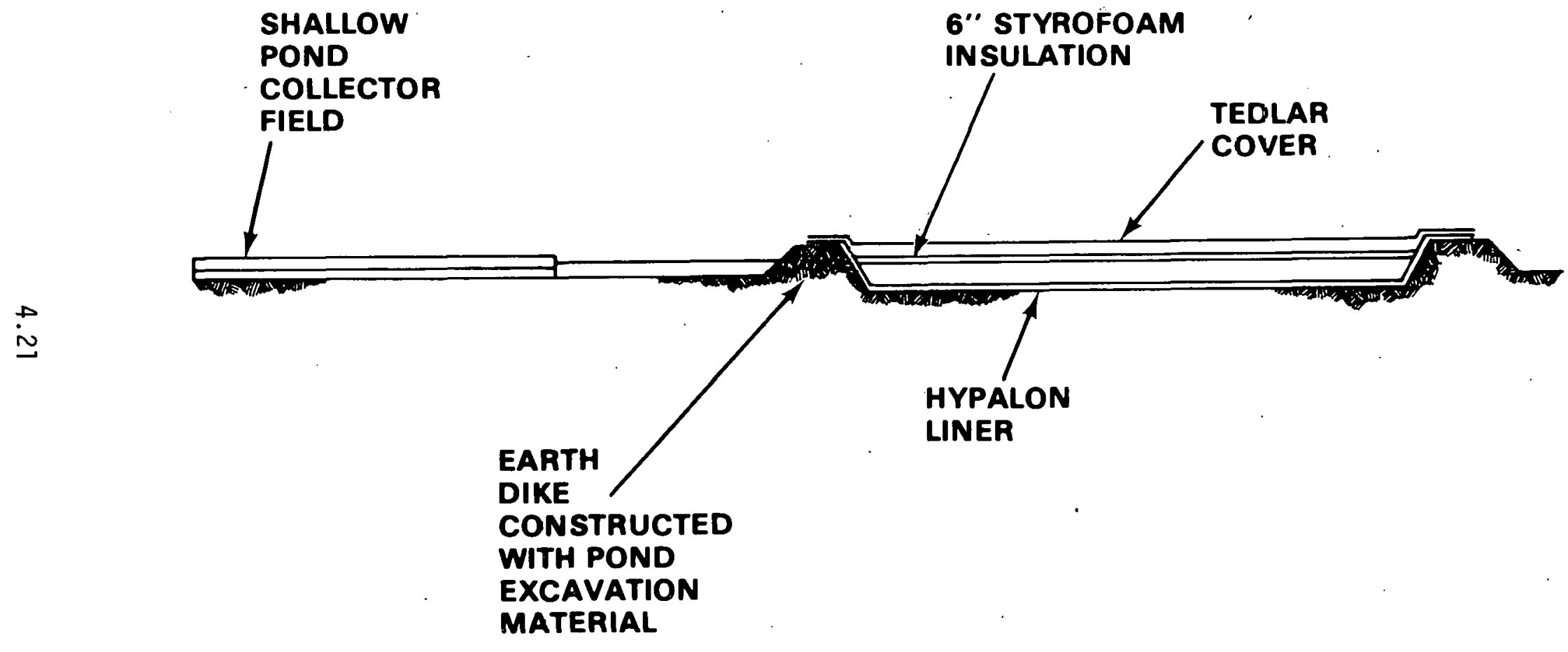

FIGURE 4.9. Storage Pond for Shallow Solar Pond Concept 


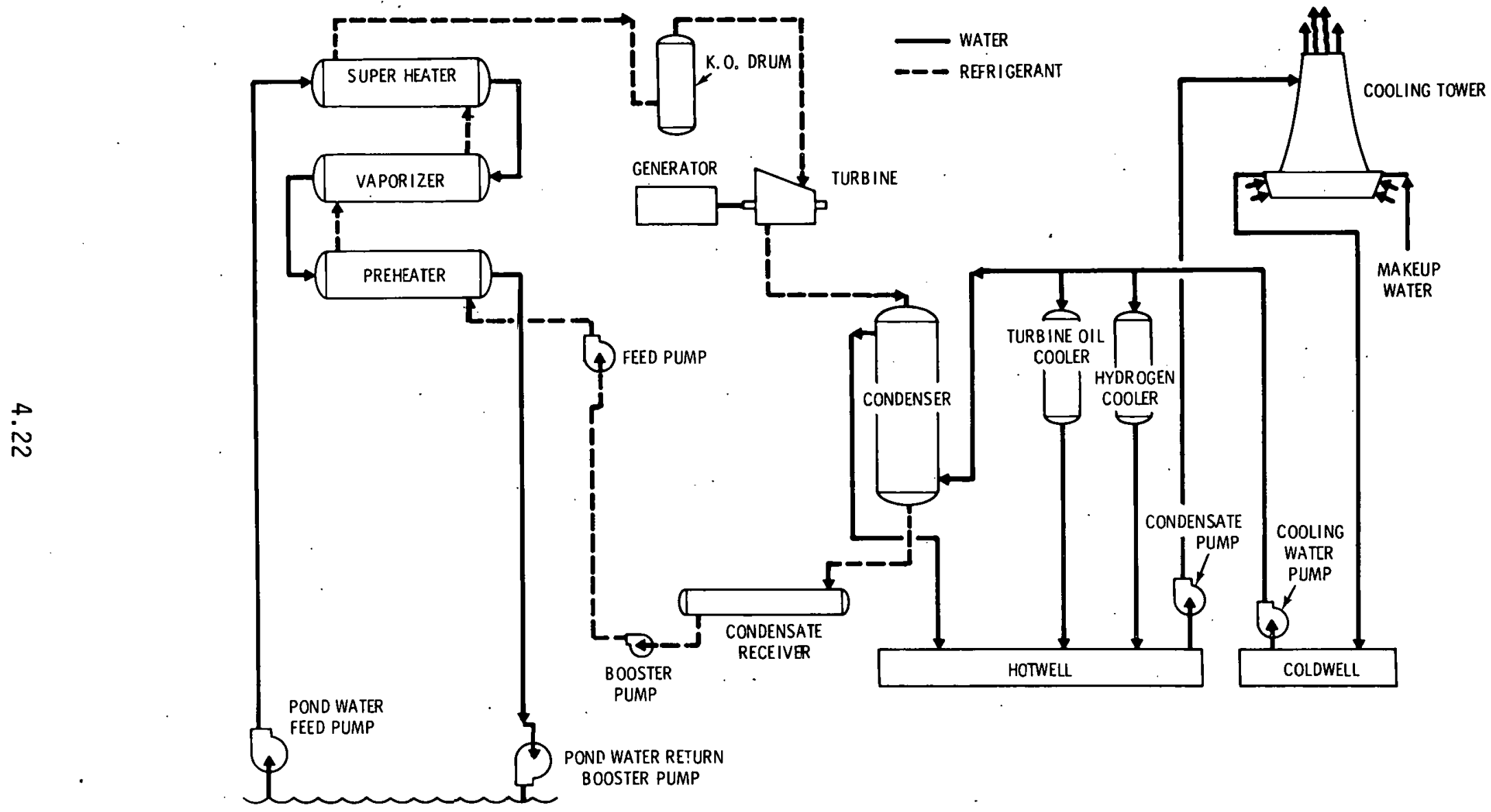

FIGURE 4.10. Binary Fluid Cycle Power Plant 


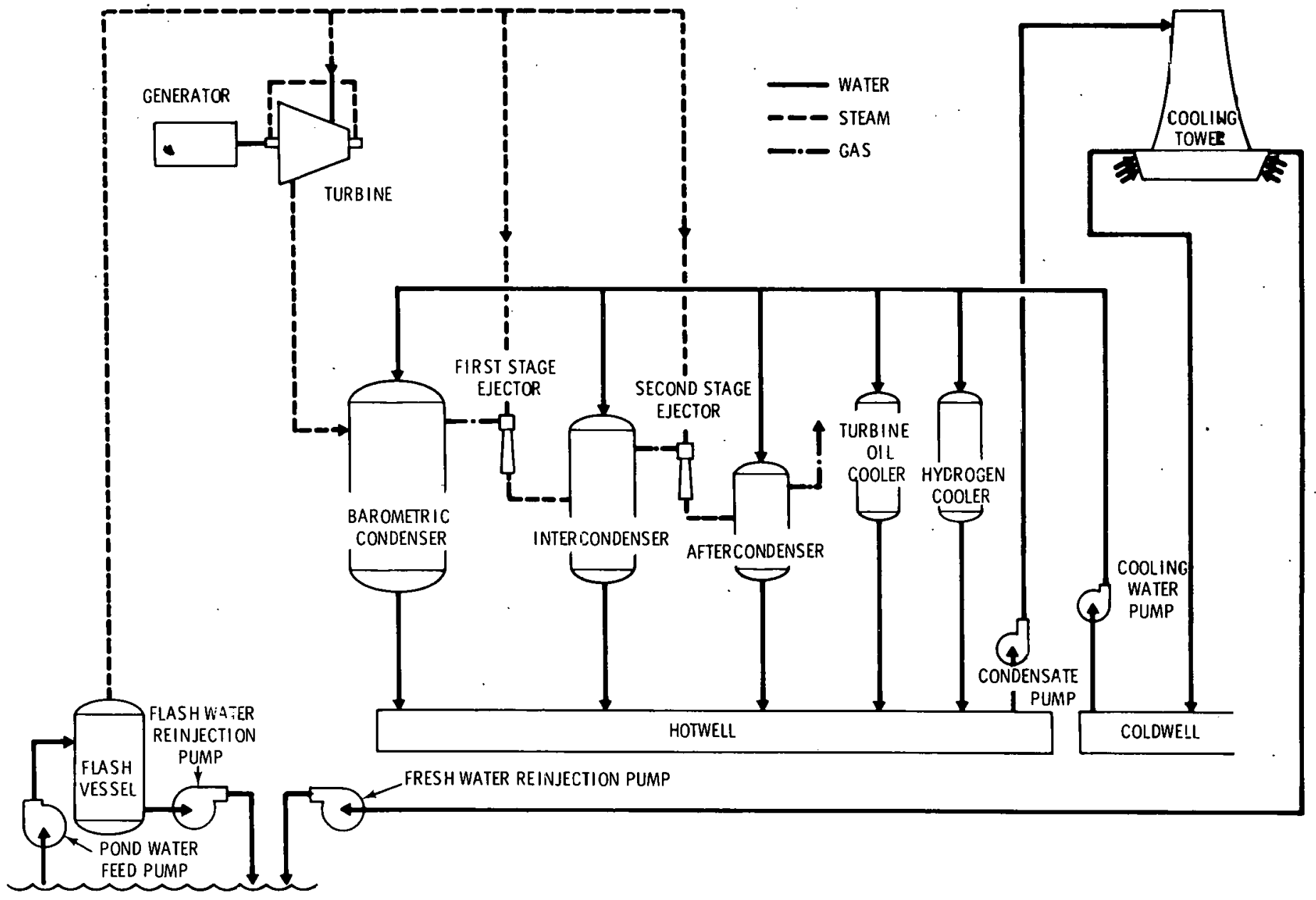

FIGURE 4.11. Flash Steam Plant 
of the pond, were selected. A binary flutd cycle power plant is more realistic than the flash cycle at present. A turbine that will operate in the flashed steam cycle conditions is not commercially available and may never be readily available unless low temperature cycles become more competitive.

A wet cooling tower was selected for cooling the working fluid due to uncertainty in the existence or use of natural features such as rivers and lakes. Dry cooling towers are more expensive and less efficient for the range of operating conditions under consideration and were not evaluated. Evaporative ponds were rejected due to extremely large requirements for makeup water and land. Use of wet cooling towers. can impose a large thermodynamic penalty with the resultant lowering of cycle efficiencies as the wet bulb temperature increases. Dry bulb temperatures of $21^{\circ} \mathrm{C}$ $\left(70^{\circ} \mathrm{F}\right)$ and a $40 \%$ relative humidity assumed for the baseline plant limit the condensing temperature of the working fluid to approximately $38^{\circ} \mathrm{C}$ $\left(100^{\circ} \mathrm{F}\right)$. The sink temperature of the Carnot cycle is the lowest available cooling water temperature (wet bulb temperature). At a source temperature of $90^{\circ} \mathrm{C}\left(194^{\circ} \mathrm{F}\right)$ the theoretical Carnot cycle efficiency therefore is:

$$
\frac{T_{\text {source }}\left(654^{\circ} R\right)-T_{\text {sink }}\left(515^{\circ} R\right)}{T_{\text {source }}\left(654^{\circ} \mathrm{R}\right)}
$$

nCarnot $=21 \%$.

\subsubsection{Binary Fluid Cycle}

The turbines associated with binary fluid cycles are much smaller than the corresponding turbines for a flashed steam plant because high molecular weight fluids such as freons, ammonia or isobutane are used. Problems with handling high salinity solutions, noncondensible gases and solids are restricted to the heat exchanger and greatly minimized. The baseline plant calculations are based on isobutane as a working fluid because the Battelle-Northwest power plant computer code (GEOCOST) includes isobutane and previous work indicated that isobutane is an appropriate working fluid over the temperature range available. 
Many questions concerning practical application of binary fluid cycles for low quality heat sources should be answered in a few short years as prototype plants are constructed for geothermal development in the Imperial Valley of California and other locations within the llniter States. Several institutions (including Battelle-Northwest) are developing comprehensive power plant computer models to permit analys is of binary fluid power plant performance over a wide range of operating conditions.

The comparative performance of the various solar pond concepts were evaluated using GEOCOST. The code covers geothermal fluids over a higher range of available temperatures (up to several hundred degrees Fahrenheit) than available from solar ponds. Therefore, operating ranges and assumptions in the GEOCOST code were modified as appropriate to suit solar pond systems. Hand calculations were also performed to verify the validity of the modifications. The thermodynamic performance affects the costs of the system in many subtle ways. The GEOCOST code was relied upon for comparative evaluation of the various concepts over a range of operating temperatures. The costs associated with the baseline plant may not be quite correct due to differences between geothermal and solar pond systems. However, the error in using the GEOCOST computer model for solar pond power plants is felt to be less than $20 \%$. The GEOCOST model is felt to be within $30 \%$ of actual geothermal power plant costs. The cumulative error for solar pond plants might be up to $50 \%$.

The installed costs and bus bar energy costs derived in this study are probably optimistic from an overall system standpoint because of the nearly ideal operating conditions assumed. Cooling water temperatures available have great effects on low $\Delta T$ heat source power plant performance. Parasitic power losses for pumping increase substantially as the cooling water temperature or pond temperature change even a few degrees.

Use of ammonia or some refrigerant other than isobutane as the cycle working fluid might improve power plant performance in the low temperature ranges available. The use of ammonia would be particularly appealing if the pond could not be maintained at $90^{\circ} \mathrm{C}$ either continuously or on a 
seasonal basis. The primary benefit derived from the use of ammonia is improved heat transfer characteristics and correspondingly smaller heat exchangers. Cycle pressures could also be higher.

A recent study by TRW, Inc. (41) assumes a value for the overall heat transfer coefficient (U) of approximately $420 \mathrm{Btu} / \mathrm{hr} \mathrm{ft}^{2}{ }^{\circ} \mathrm{F}$ using ammonia as a working fluid in titanium heat exchangers. The source temperature in the TRW study was below $27^{\circ} \mathrm{C}\left(80^{\circ} \mathrm{F}\right)$. The comparable $U$ for isobutane in the same temperature range is approximately $250 \mathrm{Btu} / \mathrm{hr} \mathrm{ft}^{2}{ }^{\circ} \mathrm{F}$. Reducing the heat exchanger area in a solar pond power plant proportionate to the ratios of the overall heat transfer coefficients for ammonia and isobutane (250/420) results in a $40 \%$ decrease. The decrease would reduce the heat exchanger area by approximately $66,000 \mathrm{ft}^{2}$ in the $90^{\circ} \mathrm{C}\left(194^{\circ} \mathrm{F}\right)$ nonconvecting salt gradient pond with an isobutane working fluid. The cost savings would be $\$ 790,000$ or $11 \%$ of the plant capital costs. Cooling water requirements would similarly be reduced. However, other considerations such as hazard to personnel and material compatibility must be factored in for ammonia cycle; the short time available for the study did not permit detalled analysis of an ammonia cycle.

The assumed cycle operating conditions are as follows:

- Inlet water from solar pond: $90^{\circ} \mathrm{C}\left(194^{\circ} \mathrm{F}\right)$

- Condensing temperature for working fluid: $36.1^{\circ} \mathrm{C}\left(97^{\circ} \mathrm{F}\right)$

- Wet cooling tower environment $\left(69^{\circ} \mathrm{F}\right.$ and $40 \%$ relative humidity): $55^{\circ} \mathrm{F}$ wet bulb

- Turbogenerator efficiency: $75 \%$

A description of the power plant section of the GEOCOST computer model follows below. Backup hand calculations are also included. Thermodynamic properties of the working fluids are calculated using equations of state rather than tabulated data. The pertinent cycle calculations from the GEOCOST program are described below:

\section{Heat Exchangers}

The preheater vaporizer and superheaters are assumed to be singlepass, counter-flow, shell-and-tube type heat exchangers. The isobutane 
preheater, vaporizer and superheater equations below are set up to determine a heat transfer area from which a cost is determined, based on a rate of $\$ 12 / \mathrm{ft}^{2}$ of surface area required. Heat transfer coefficients are derived from actual working fluid properties determincd from equations of state. The heat transfer area in square feet is determined by the following relationship:

$$
\text { Heat transfer area }=\frac{\dot{m} \Delta h}{U(L M T D)}
$$

where

$$
\begin{aligned}
\dot{\mathrm{m}} & =\text { mass flow rate of isobutane }(\mathrm{lb} / \mathrm{hr}) \\
\Delta \mathrm{h} & =\text { change in isobutane enthalpy }(\mathrm{Btu} / 1 \mathrm{~b}) \\
U & =\text { overall heat transfer coefficient }\left(\mathrm{Btu} / \mathrm{hr} \cdot \mathrm{ft}^{2} \cdot{ }^{\circ} \mathrm{F}\right) \\
\text { LMTD } & =\text { Log Mean Temperature Difference }\left({ }^{\circ} \mathrm{F}\right) \\
& =\frac{\Delta t \text { inlet }-\Delta t \text { outlet }}{\ln \left(\frac{\Delta \mathrm{t} \text { inlet }}{\Delta \mathrm{t} \text { outlet }}\right)} .
\end{aligned}
$$

To determine the overall heat transfer coefficient $(U)=$ $\frac{1}{U}=\frac{D_{0}}{H T C_{i}\left(D_{i}\right)}+\frac{D_{0}}{2 K} \ln \frac{D_{0}}{D_{i}}+\frac{1}{H T C_{0}}+$ (fouling factor)

where

$D_{0}=$ outside tube diameter $(f t)$

$D_{i}=$ inside tube diameter

$\mathrm{HTC}_{i}=$ inside heat transfer coefficient $\left(\mathrm{Btu} / \mathrm{hr} \mathrm{ft}^{2}{ }^{\circ} \mathrm{F}\right.$ )

$\mathrm{HTC}_{0}=$ outside heat transfer coefficient

$K=$ thermal conductivity of heat exchanger tube material (Btu/hr $\mathrm{ft}^{2}{ }^{\circ} \mathrm{F}$ )

Fouling

Factor $=0.001 \mathrm{hr}{ }^{\circ} \mathrm{F}^{2} \mathrm{ft}^{2} /$ Btu.

The fouling factor is based on typical values for concentrated brines. The heat transfer coefficient (HTC) is determined as follows:

$$
H T C=\frac{(0.023) K_{f l u i d}(P r)^{0.3}(R e)^{0.8}}{D}
$$


where

$$
\begin{aligned}
K_{\text {fluid }} & =\text { thermal conductivity }(B t u / h r \\
P r & =\text { Prandt } 1 \text { number } \\
\operatorname{Re} & =\text { Reynolds number } \\
D & =\text { tube diameter }(\mathrm{ft}) .
\end{aligned}
$$

The solar pond water runs through the tube side of the preheater, vaporizer and superheater. The number of tubes and length were derived from conventional heat exchanger design methods. Sufficient heat is added in the superheater to avoid two-phase flow through the turbine. The vaporizer changes the working fluid from a saturated liquid to a saturated vapor. The preheater heats the working fluid from the condensing temperature to a saturated liquid state.

\section{Turbine Generator}

A conventional turbine was assumed for the power plant. Only one turbine is known to have been manufactured in the United States specifically for binary fluid cycles. The turbine is a $9,000 \mathrm{~kW}_{e}$, three-stage, radial-flow unit designed for isobutane and is manufactured by the York Division of Borg-Warner Corporation for Magma Energy, Inc. (42)

The turbine exhaust conditions are established by the condenser cooling water temperature available. Isentropic expansion is assumed through the turbine. The theoretical steam rate (TSR) in pounds of vapor per $\mathrm{kW}_{\mathrm{e}}$ is established from the following relationship:

$$
T S R=\frac{3414}{h_{\text {in let }}-h_{\text {cond }}}
$$

where

$$
\begin{aligned}
h_{\text {inlet }}= & \text { enthalpy of the vapor from the } \\
& \text { superheater }(B t u / 1 b) \\
h_{\text {cond }}= & \text { enthalpy of the working fluid } \\
& \text { at condenser conditions }
\end{aligned}
$$

The actual steam (or vapor) rate is determined by dividing the theoretical steam (TSR) by the turbine efficiency $(\sim 75 \%)$. 


\section{Condenser}

The working fluid condenser for the binary fluid cycle is assumed to be a single-pass, counter-flow, shell-and-tube type similar to the superheater, vaporizer and preheater. The equations are the same as those tabulated earlier for the heat exchangers (superheater, vaporizer and preheater.) Inputs include inlet and outlet cooling water temperatures, working fluid enthalpies, temperatures and pressures, working fluid properties and flow rate and tube diameters. The output is the condensing water flow rate, condenser area and length, and the individual heat transfer coefficients. The condenser costs are based on the same price per square foot $(\$ 12.00)$ as the other heat exchangers.

\section{Pumps}

A11 system pumps are standard centrifugal units driven by an electric motor. Power consumption for pumping fluids is based on an $85 \%$ efficiency. A $90 \%$ efficiency was assumed for the cooling tower fan motor. Discharge heads are based on normal pressure drops through conventional heat exchangers and the elevation required for cooling tower entrance.

\section{Cooling Tower}

The cooling tower used in the GEOCOST computer model is an induceddraft evaporative cooling tower. Operating conditions assumed were $55^{\circ} \mathrm{F}$ wet bulb. Inputs to the cooling tower equations include cooling water flow rate and temperature at the inlet, wet and dry bulb air temperatures, humidity ratio and approach. Output values include the cooling tower air flow rate, evaporation rate and overall heat load. Costs of the cooling tower are based on a fixed cost for the gross plant power output $\left(\$ 720,000\right.$ for $10 \mathrm{MW}_{\mathrm{e}}$ plant $)$.

The heat load to the cooling tower in Btu/hr =

$$
Q_{w_{\text {in }}} \times C_{P_{1}}\left(T_{w_{\text {in }}}-T_{w_{\text {out }}}\right)-Q_{L A} C_{P_{2}}\left(T_{L A}-T_{C I}\right)
$$

where: 


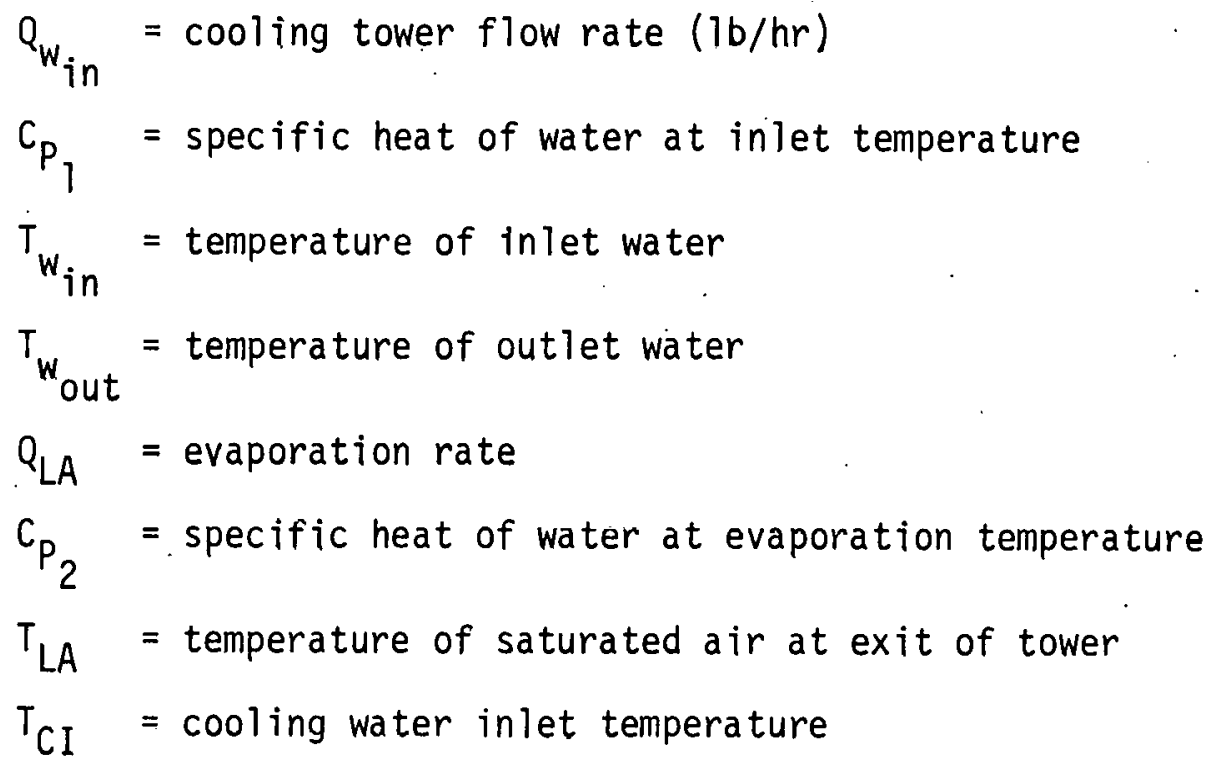

\section{Calculation of Thermodynamic State Points}

The state points for a sub-critical binary fluid cycle are shown in Figure 4.12 .

In general, the final state points are established by an iterative method based on cooling water temperature, heat exchanger approach, heat exchanger pinch points and the final temperature of the solar pond fluid. The computer runs for several binary cycle plants over a range of inlet pond water temperatures are shown in Section 5.

An approximate hand calculation based on textbook values of the baseline binary fluid cycle power plant is included below for the nonconvecting salt gradient pond.

Hand Calculation of Power Plant Operating Conditions and Costs

The following baseline plant assumptions are used for the cycle calculations:

- Inlet pond water: $25 \mathrm{wt} \%$ salt at $90^{\circ} \mathrm{C}\left(194^{\circ} \mathrm{F}\right)$

- Condensing temperature [based on wet cooling tower at $13^{\circ} \mathrm{C}\left(55^{\circ} \mathrm{F}\right)$ wet bulb operating over a $\left(25^{\circ} \mathrm{F}\right)$ range with a $\left(12^{\circ} \mathrm{F}\right)$ approach $]: 32.1^{\circ} \mathrm{C}$ $\left(97^{\circ} \mathrm{F}\right)$.

- Working fluid: isobutane 


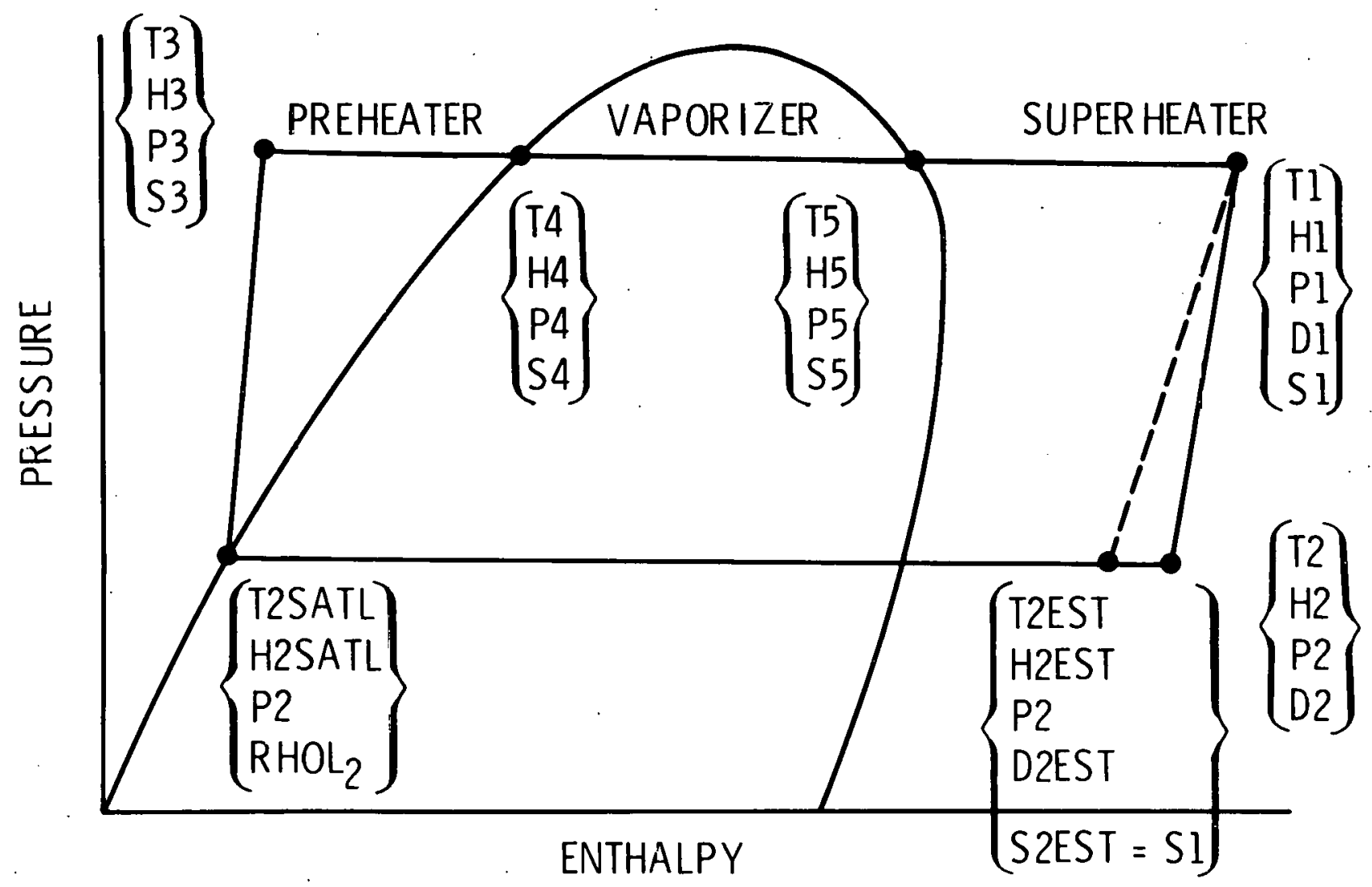

FIGURE 4.12. Thermodynamic State Points for Binary Fluid Cycle 
- Turbine efficiency: $75 \%$

- Pressure drop in heat exchangers: 10 psi each

- Pumping head required for cooling tower entrance: $45 \mathrm{ft}$

- Pressure drop in condenser: 10 psi

Assuming a $\left(10^{\circ} \mathrm{F}\right)$ pinch point in the vaporizer and no superheat, the maximum temperature of the isobutane working fluid in the cycle is $10^{\circ}$ less than the incoming pond water $90^{\circ} \mathrm{C}\left(194^{\circ} \mathrm{F}\right)$. Therefore, the maximum isobutane temperature is $84^{\circ} \mathrm{C}\left(184^{\circ} \mathrm{F}\right)$ which corresponds to a maximum cycle pressure of 212.5 psia. A maximum cycle operating pressure of 185 psia was selected to permit superheat of the working fluid (and thus avoid two-phase flow) and also to accommodate a temperature approach greater than $10^{\circ} \mathrm{F}$ in the superheater. The maximum cycle pressure of 185 psia corresponds to a maximum temperature of $79^{\circ} \mathrm{C}\left(174^{\circ} \mathrm{F}\right.$ ) (including $2^{\circ} \mathrm{F}$ superheat). Figure 4.13 shows the state point values for the isobutane cycle.

The ideal Rankine efficiency for the isobutane cycle is:

$$
\begin{aligned}
\left(n_{R}\right) & =\frac{h_{1}-h_{2} \text { est }}{h_{1}-h_{2} \text { sat } 1 \text { iq }} \\
n_{R} & =\frac{-627+644}{-627+784}=10.8 \% \text { (idea ) ) }
\end{aligned}
$$

The flow rate of the isobutane working fluid $\left(Q_{W f}\right)$ is determined from the following relationship:

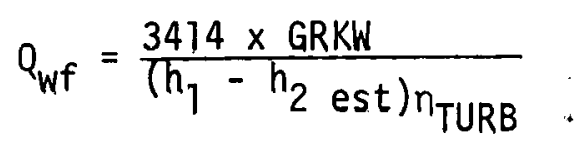

where

$$
\begin{aligned}
& h_{1}=\text { enthalpy at turbine inlet (Btu/hr) } \\
& h_{2} \text { est }=\text { exhaust enthalpy assuming isentropic expansion } \\
& \left.n_{\text {TURB }}=\text { turbine efficiency (assumed to be } 75 \%\right) \\
& \text { GRKW }=\text { turbine output in kilowatts } \\
& Q_{w f}=\frac{3414 \times 10,000}{(-627+644) 0.75} \\
& Q_{w t}=2.68 \times 10^{6} \mathrm{lb} \text { of isobutane per hour }
\end{aligned}
$$




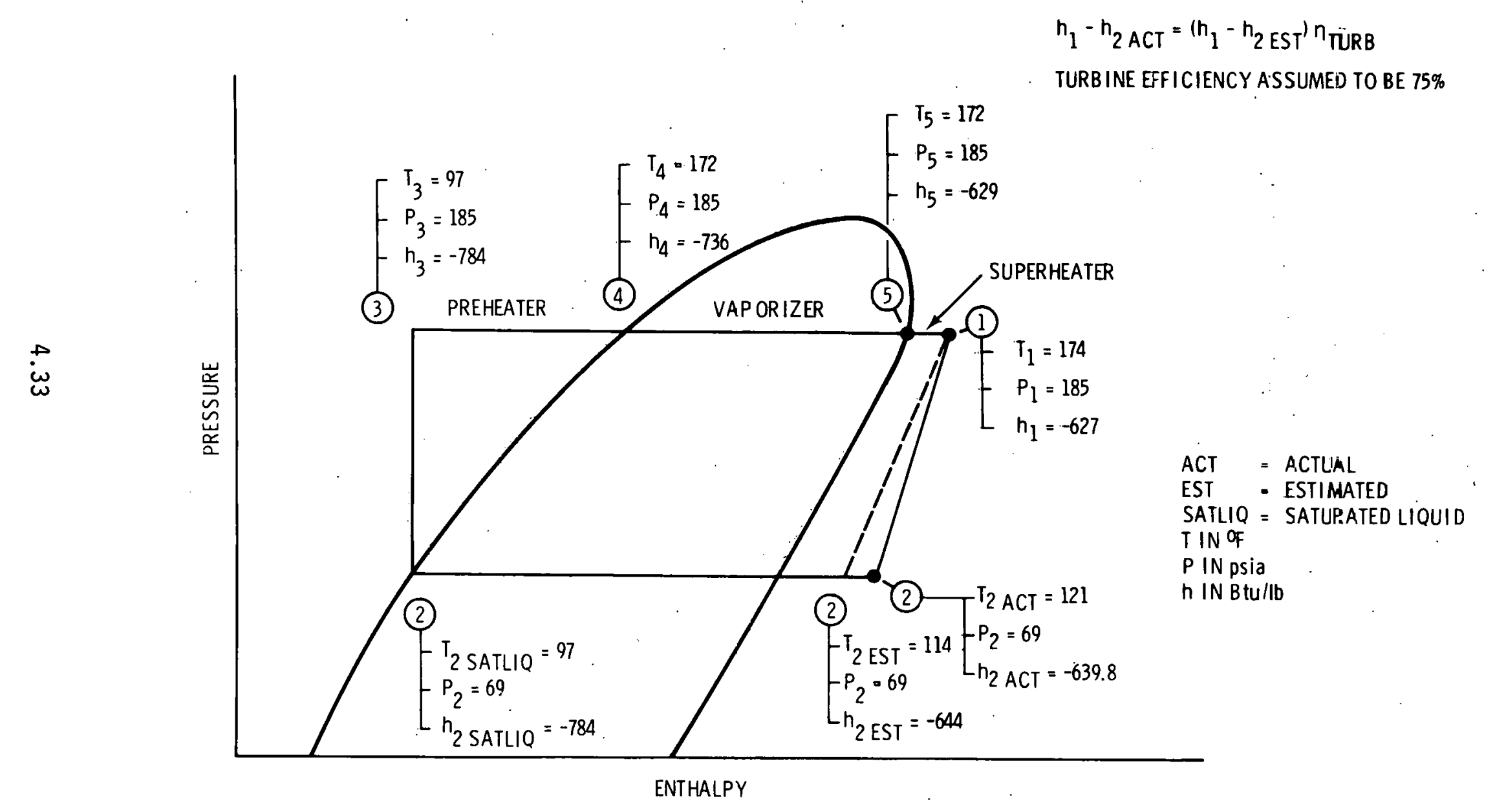

FIGURE 4.13. State Point Values of Working Fluid 
The flow rate of pond water $\left(Q_{p w}\right)$ is determined by calculating a heat balance on the vaporizer and superheater.

$$
Q_{p w} C_{p}\left(T_{\text {inlet }}-T_{p p}\right)=Q_{w f}\left(h_{1}-h_{4}\right)
$$

where

$$
\begin{aligned}
C_{p}= & \text { specific heat of pond water at constant pressure } \\
& \approx 1.0 \mathrm{Btu} / \mathrm{lb} \\
T_{i n l e t}= & \text { inlet pond water temperature }=90^{\circ} \mathrm{C}\left(194^{\circ} \mathrm{F}\right) \\
T_{p p \quad=} & \text { pinch point temperature }=83^{\circ} \mathrm{C}\left(182^{\circ} \mathrm{F}\right) \quad \text { (see explana- } \\
& \text { tion directly below) } \\
h_{1}= & \text { enthalpy of working fluid at outlet of super- } \\
& \text { heater }=-627 \mathrm{Btu} / 1 \mathrm{~b} \\
\mathrm{~h}_{4} \quad & \text { enthalpy of working fluid at inlet to } \\
& \text { vaporizer }=-736 \mathrm{Btu} / \mathrm{b}
\end{aligned}
$$

The vaporizer pinch point temperature is the minimum temperature difference between the pond water and the working fluid in the vaporizer as shown in Figure 4.14.

$$
Q_{p w}=\frac{2.68 \times 10^{6}(-627+736)}{1.0(194-182)}=2.43 \times 10^{7} \mathrm{lb} / \mathrm{hr}
$$

adding $25 \%$ for the salt concentration

$$
Q_{p w}=3.04 \times 10^{7} \mathrm{lb} / \mathrm{hr}(49,000 \mathrm{gpm})
$$

To calculate the exit temperature of the pond water, a heat balance is performed around the preheater using the same pinch point as above:

$$
\begin{aligned}
& Q_{w t}\left(h_{4}-h_{2} \text { SATL }\right)=Q_{p w}\left(T_{p p}=T_{\text {exit }}\right) C_{p} \\
& T_{\text {exit }}=\frac{3.04 \times 10^{7}(182)-(2.68) \times 10^{6}(-736+784)}{3.04 \times 10^{7}} \\
& T_{\text {exit }}=177.7^{\circ} \mathrm{F}
\end{aligned}
$$




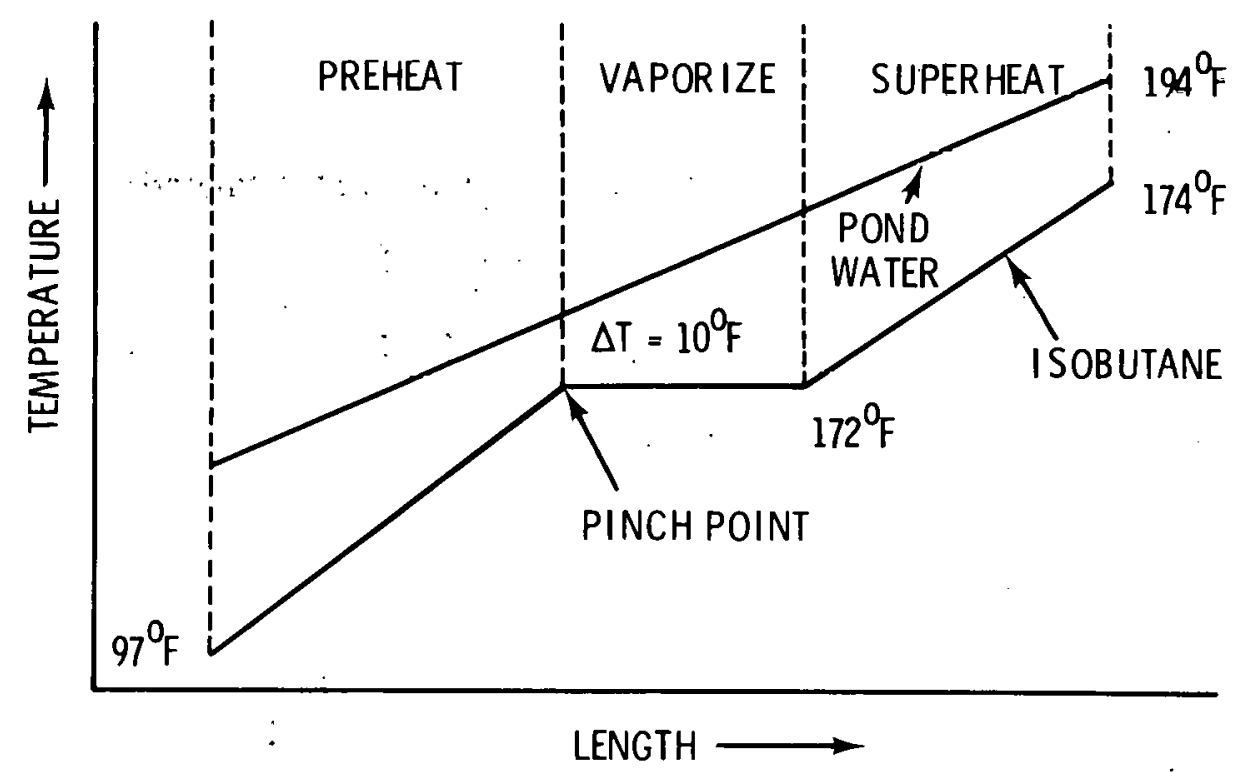

FIGURE 4.14. Vaporizer Pinch Point Temperature

Calculate heat rate $(q)$ in heat exchangers (vaporizer, preheater and superheater):

$$
\begin{aligned}
q & =Q_{w t}\left(h_{3}-h_{1}\right) \\
& =2.68 \times 10^{6}(-784+627) \\
& =4.21 \times 10^{8} \mathrm{Btu} / \mathrm{hr}
\end{aligned}
$$

To calculate surface areas of evaporator, preheater and superheater:

$$
A=\frac{q}{U \times \text { LMTD }}
$$

where

$$
\begin{aligned}
& q=\text { heat rate }=Q_{W f} \Delta h \\
& U=\text { overail heat transfer coefficient, Btu/hr } \mathrm{ft}^{2}{ }^{\circ} \mathrm{F}
\end{aligned}
$$




$$
\begin{aligned}
\text { LMTD } & =\log \text { Mean Temperature Difference }\left({ }^{\circ} \mathrm{F}\right) \\
& =\frac{\Delta t_{\text {in }}-\Delta t_{\text {out }}}{\ln \frac{\Delta t_{\text {in }}}{\Delta t_{\text {out }}}}
\end{aligned}
$$

The following overall heat transfer coefficients were assumed:

preheater and superheater: $100 \mathrm{Btu} / \mathrm{hr} \mathrm{ft}^{2}{ }^{\circ} \mathrm{F}$

vaporizer: $\quad 250 \mathrm{Btu} / \mathrm{hr} \mathrm{ft}^{2}{ }^{\circ} \mathrm{F}$

For the vaporizer (refer to Figure 4.13):

$$
\begin{aligned}
& A=Q_{W f} \frac{\left(h_{5}-h_{4}\right)}{250 \frac{B t u}{h r} f t^{2} \circ F}\left[\frac{(193-172)-(182-172)}{\ln \frac{21}{10}}\right] \\
& A=77,400 \mathrm{ft}^{2}
\end{aligned}
$$

For the preheater:

$$
\begin{aligned}
A & =\frac{Q_{W f}\left(h_{4}-h_{3}\right)}{100\left[\frac{(182-172)-(177.7-97)}{\ln \frac{10}{80.7}}\right]} \\
A & =38,000 \mathrm{ft}^{2}
\end{aligned}
$$

For the superheater:

$$
\begin{aligned}
& A=\frac{Q_{w f}\left(h_{1}-h_{5}\right)}{100 \frac{(194-174)-(193-174)}{\ln \frac{20}{19}}} \\
& A=2,750 \mathrm{ft}^{2}
\end{aligned}
$$

Total surface area for superheater, vaporizer and preheater $=2,750+$ $38,000+77,400=118,000 \mathrm{ft}^{2}$ 
To calculate surface area of the condenser:

$$
A=\frac{Q_{W f}\left(h_{2} \text { ACT }-h_{2} \text { SAT LIQ }\right)}{U \times \text { LMTD }}
$$

Inlet temperature of working fluid $=\mathrm{T}_{2} \mathrm{ACT}=49^{\circ} \mathrm{C}\left(121^{\circ} \mathrm{F}\right)$

Condensing temperature $=36^{\circ} \mathrm{C}\left(97^{\circ} \mathrm{F}\right)$

Inlet water conditions to condenser $=19^{\circ} \mathrm{C}\left(67^{\circ} \mathrm{F}\right)$

Outlet water conditions from condenser $=33^{\circ} \mathrm{C}\left(92^{\circ} \mathrm{F}\right)$

Assume $U=250 \mathrm{Btu} / \mathrm{hr} \mathrm{ft}^{2}{ }^{\circ} \mathrm{F}$

$$
\begin{aligned}
& A=\frac{2.68 \times 10^{6}(-639.8+784)}{250\left[\frac{(121-67)-(97-92)}{\ln \frac{54}{5}}\right]} \\
& A=75,000 \mathrm{ft}^{2}
\end{aligned}
$$

Cooling tower flow $\left(Q_{c t}\right)$ :

$$
\begin{aligned}
Q_{c t} C_{p}\left(T_{\text {out }}-T_{\text {in }}\right) & =Q_{W f}\left(h_{2} A C T-H_{2} \text { SAT LIQ }\right) \\
Q_{c t} & =\frac{2.68 \times 10^{6}(-639.8+784)}{1(92-67)} \\
Q_{c t} & =1.54 \times 10^{7} 1 \mathrm{p} / \mathrm{hr}
\end{aligned}
$$

Cooling tower heat load:

$$
\begin{aligned}
& q=Q_{c t}\left(h_{\text {outlet }}-h_{\text {inlet }}\right) \\
& h_{\text {inlet }}=\text { enthalpy of water at } 67^{\circ} \mathrm{F}=35.05 \mathrm{Btu} / 1 \mathrm{~b} \\
& h_{\text {outlet }}=\text { enthalpy of water at } 92^{\circ} \mathrm{F}=61.98 \mathrm{Btu} / 1 \mathrm{~b} \\
& q=1.54 \times 10^{7}(61.98-31.05) \\
& q=4.76 \times 10^{8} \mathrm{Btu} / \mathrm{hr}
\end{aligned}
$$




\subsubsection{Flash Steam Cycle}

A flashed steam cycle is more straightforward than the binary fluid cycle. A power plant diagram was shown in Figure 4.11. The flashed steam cycle has the added advantage of providing fresh water for pond make-up and concentrating the brine without the auxiliary equipment required for the binary fluid cycle. Standard turbines are not commercially available for the available range of operating pressures. Turbine efficiency could well be so low (probably well under 50\%) that potential benefits would be cancelled by high costs and poor performance. The short duration of the study did not permit an evaluation of steam engines in lieu of turbines. However, steam engines should be examined in detail before the concept of a flashed steam cycle is discarded. The performance data for flashed steam plants appear in the tables at the end of Section 5.0.

The ideal Rankine cycle efficiency for a flashed steam plant over the above range of conditions, assuming a practical exhaust pressure of 2 psia and the flashed steam at $71^{\circ} \mathrm{C}\left(160^{\circ} \mathrm{F}\right)$ is:

$$
\text { nRankine }=\frac{h_{1}-h_{2} \text { estimated }}{h_{1}-h_{2} \text { sat. liquid }}
$$

where

$$
\begin{aligned}
& \mathrm{h}=\text { enthalpy in Btu/1b, sat. liquid = saturated liquid and } \\
& h \text { estimated is based on isentropic expansion through the } \\
& \text { turbine. } \\
& n \text { Rankine }=\frac{1129.9-1035}{1120.9-68}=8.9 \%
\end{aligned}
$$

Subtracting the losses due to pressure drops, turbine efficiency, pumping losses, etc., the actual Rarikine efficiency is below this value. The actual Rankine cycle efficiency is less than one-third of the Carnot efficiency.

The quantity of steam that will flash from solar pond fluid is based on the following assumptions: 
- Fresh water at $90^{\circ} \mathrm{C}\left(194^{\circ} \mathrm{F}\right)$ and one atmosphere (14.7 psia)

- To compensate for salt, add $25 \%$ (or percent concentration) to required flow of pond water

- Enthalpy of fresh water at $50^{\circ} \mathrm{C}\left(194^{\circ} \mathrm{F}\right)=162 \mathrm{Btu} / 1 \mathrm{~b}$ (from Combustion Engineering Steam Tables)

- The heat contribution of the salt in solution is negligible

Steam fraction recovered $(X)$ in steam $1 b /$ water $1 b$ in a flash vessel:

$$
\begin{aligned}
& X=\frac{h_{\text {in }}-h_{\text {saturated liquid }}}{h_{\text {vapor }}-h_{\text {saturated liquid }}} \\
& h_{\text {in }}=\text { enthalpy of entering water from } \\
& \text { pond }=162 \mathrm{Btu} / 1 \mathrm{~b} \text { at } 50^{\circ} \mathrm{C}\left(194^{\circ} \mathrm{F}\right) \\
& h_{\text {saturated } 1 \text { iquid }}=\text { enthalpy of pond water leaving } \\
& \text { flash vessel }
\end{aligned}
$$

The maximum steam fraction recoverable from fresh water is obtained by evacuating to near absolute zero pressure:

$$
X=\frac{162-0}{1075.1-0}=15.1 \%
$$

or 15.1 1b of steam per 100 1b of fresh water. For $25 \%$ salt solutions, an additional $25 \%$ flow of water would be required. The maximum steam fraction recoverable from a $25 \%$ salt solution is therefore $15.1 \mathrm{lb} / 125 \mathrm{lb}$ water, or $12.1 \%$.

The pressure in the flash vessel must be balanced against the lowest practical condenser pressure (approximately 2 psia) and the pressure drop across the turbine. Decreasing the pressure in the flash vessel to produce more steam results in a lower pressure drop across the turbine and an increasingly larger turbine. Time did not permit optimization of the pressure balance between the flash vessel turbine and the condenser. A common method is to average the temperatures as follows: 


$$
\begin{aligned}
& T_{F}=T_{\text {Win }}-\frac{\left(T_{\text {Win }}-T_{\text {cond. }}\right)}{2 \cdot} \\
& T_{F}=\text { temperature of flashed steam } \\
& T_{\text {Win }}=\text { temperature of water from solar pond }=90^{\circ} \mathrm{C}\left(194^{\circ} \mathrm{F}\right) \\
& T_{\text {cond. }}=\text { temperature of saturated } 1 \text { iquid at a practical condenser } \\
& \quad \text { pressure }\left(2 \text { psia) } \simeq 52^{\circ} \mathrm{C}\left(126^{\circ} \mathrm{F}\right)\right. \\
& T_{F}=194-\frac{(194-126)}{2}=194-34=71^{\circ} \mathrm{C}\left(160^{\circ} \mathrm{F}\right)
\end{aligned}
$$

Figure 4.15 shows the steam fraction recovered versus temperature for fresh water and a $25 \%$ salt solution. For the $71^{\circ} \mathrm{C}\left(160^{\circ} \mathrm{F}\right)$ average temperature selected:

$$
\begin{aligned}
& \begin{array}{l}
\text { steam fraction recovered }(X)=\frac{162-127.87}{1129.9-127.87} \\
\text { from fresh water }
\end{array} \\
& X=0.0341 \text { or } 3.41 \% \\
& \text { steam fraction recovered }(x)=0.0341 \frac{(100)}{125}(100) \\
& \text { from pond solution } \\
& X=2.72 \%
\end{aligned}
$$

\section{Steam Flash Vessel}

The flashed steam cycle begins in a flashing vessel where the pressure is reduced on the pond water entering at approximately one atmosphere $(14.7 \mathrm{psia})$ and $90^{\circ} \mathrm{C}\left(194^{\circ} \mathrm{F}\right)$. The flash vessel would probably require steam ejectors to remove noncondensible gases in the pond water. The optimum temperature for flashing is a function of the cooling water temperature available (or condensing temperature), the inlet pond water enthalpy and the pumping power required to move the pond water to the flash evaporator. The optimum flash conditions are normally very nearly equal to. the average of the incoming pond water and condensing temperatures. A diagram of steam fraction flashed verșus temperature is shown in Figure 4.15 . 


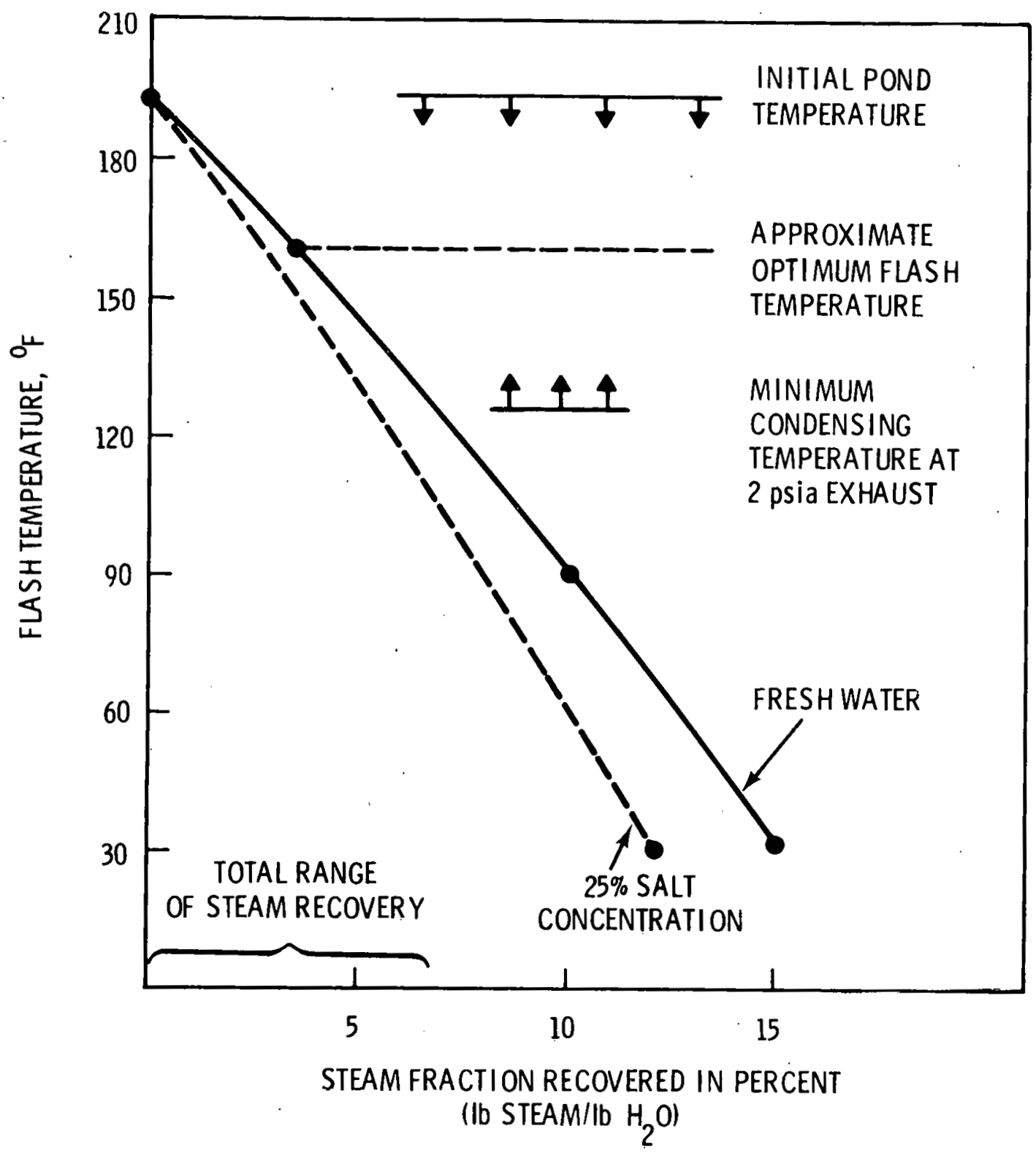

FIGURE 4.15. Steam Recovery Versus Temperature for $90^{\circ} \mathrm{C}$ Solar Pond 
The condensing temperature of $52^{\circ} \mathrm{C}\left(126^{\circ} \mathrm{F}\right)(2$ psia pressure) is based upon experience with barometric condensers at the Geysers geothermal steam plant near San Francisco. The lower condenser pressures (2-3 in. Hg absolute) attained in large central power plants are possible because highly purified and recycled water is being used. Solar pond water would likely not be treated to remove dissolved gases and other impurities.

\section{Turbine}

The low molecular weight and corresponding high specific volume of steam at pressures below one atmosphere require relatively large turbines for a fixed power output as compared to high molecular weight vapors such as freons, propane or isobutane used in binary fluid cycles. The current trend in conversion of other low quality heat sources, such as geothermal and ocean thermal $\Delta \mathrm{T}$, to electricity is to employ binary fluid cycles primarily for that reason. The binary fluid cycle has other advantages in handling of salt solutions and vapors where noncondensible gases exist. The binary fluid cycle is felt superior for the power plant in nonconvecting salt pond. However, other considerations such as the need for providing fresh makeup water to both the pond and cooling tower and the necessity of continuously concentrating the brine in the lower portion of the pond make an open flashed-steam cycle attractive for the present application. However, the availability of turbines to operate at the available steam conditions is doubtfit. The use of steam engines or other rotary expansion machines could not be investigated within the framework of the present study.

The approximate steam flow rate to the turbine (Qstm) is determined from the relationship below:

$$
\text { Qstm }=\frac{3414 \times \text { GRKW }}{\left(h_{1}-h_{2} \text { est }\right)} \eta \text { turb }
$$

where

GRKW is the gross turbine output in kilowatts $(10,000$ for the baseline plant) 


$$
\begin{aligned}
h_{1}= & \text { enthalpy of steam entering turbine from flash } \\
& \text { vessel }=1129.9 \mathrm{Btu} / 1 \mathrm{~b} \\
\mathrm{~h}_{2} \text { Est = } & \text { enthalpy of steam at turbine exhaust pressure (2 psia) } \\
& \text { assuming isentropic expansion (from stcam tables) } \\
\text { nTurb = } & \text { turbine efficiency }
\end{aligned}
$$

For a turbine efficiency of $75 \%$ :

$$
\text { Qstm }=\frac{3414 \times 10,000}{(1129.9-1075)}(0.75)=8.29 \times 10^{5} \mathrm{lb} / \mathrm{hr}
$$

Approximately $5 \%$ of the steam would be required to evacuate and remove noncondensible gases from the flash vessel and condenser based on experience at the Geysers geothermal power plant.

The steam flow rate is inversely proportional to turbine efficiency. A steam flow rate of approximately $1,500,000 \mathrm{lb} / \mathrm{hr}$ would be required for a turbine with $40 \%$ efficiency.

The flow of pond water corresponding to the steam flow rate of $8.29 \times 10^{5} \mathrm{lb} / \mathrm{hr}$ is:

$1 \mathrm{~b}$ pond water $/ \mathrm{hr}=\frac{\text { Steam flow rate }}{\text { Steam }}$

$$
=\frac{8.29 \times 10^{5}}{0.0272}=3.0 \times 10^{7} \mathrm{lb} / \mathrm{hr}
$$

Adding $5 \%$ for the steam required for ejectors and converting to gallons per minute:

$$
\frac{3.0 \times 10^{7}}{10.43 \mathrm{bb} / \mathrm{ga} / \mathrm{hr} / \mathrm{hr}}(1.05) \frac{1}{60 \mathrm{~min} / \mathrm{hr}} \simeq 50,335 \mathrm{gpm}
$$

A $40 \%$ efficient turbine would require approximately $100,000 \mathrm{gpm}$ flow from the solar pond.

The turbine diameter can be roughly estimated by calculating the pipe. diameter required for a flow of steam at $200 \mathrm{ft} / \mathrm{sec}$ at specific volume of the entering steam. (43) 
Specific volume of inlet steam $\approx 77 \mathrm{ft}^{3} / 1 \mathrm{~b}$. Assuming a steam flow rate of $8.29 \times 10^{5} \mathrm{~Tb} / \mathrm{hr}$ and using the relationship $Q=\rho A v$.

where:

$$
\begin{aligned}
Q= & \text { flow rate } \\
\rho= & \text { density } \\
V= & \text { velocity } \\
A= & \frac{8.29 \times 10^{5} 1 \mathrm{~b} / \mathrm{hr}}{\frac{1}{77} \mathrm{ft}^{3} / 1 \mathrm{~b}} 200 \mathrm{ft} / \mathrm{sec} 3600 \mathrm{sec} / \mathrm{hr}=88.6 \mathrm{ft}^{2} \\
& \text { equivalent diameter }=10.62 \mathrm{ft}(3.2 \mathrm{~m})
\end{aligned}
$$

Turbines with a $10 \mathrm{ft}$ diameter would be very expensive and are not manufactured for the range of pressure available from solar pond steam. Two steam turbines purchased in 1964 for the N-Reactor at Hanford were among the largest turbines specifically built for low temperature application. Each cost $\$ 9,100,000$. These turbines have a rated output of $440 \mathrm{MW}_{\mathrm{e}}$ and the longest blades are $41 \mathrm{in}$. The cost of similar turbines today is estimated to be $\$ 20,000,000$. An estimate of $\$ 10,000,000$ for the turbine was used for the flashed steam plant calculations summarized in Tables 5.4 and 5.5 , this may be below the eventual cost.

Flashed steam plants would be more sensitive to seasonal fluctuations in the solar pond than binary fluid cycles. The sensitivity is due to the narrow range of pressure available between the incoming pond water and the condensing pressure.

\section{Condenser}

Barometric condensers are presently being used for geothermal steam applications where the purity of the incoming fluid cannot be controlled. It is felt that the solar pond water will similarly require barometric condensers operating at condenser pressures of approximately 2 psia. The condenser and flash vessel are evacuated by steam ejectors which require approximately $5 \%$ of the total flow to the turbines. 


\section{Cooling Tower}

Wet cooling towers with induced draft (cross flow) were selected to provide cooling water for the condenser. Dry cooling towers and natural draft water cooling towers would both be more expensive and less cfficient. Rivers and cooling lakes or ponds were rejected because comparative data is lacking and the makeup water requirements are very high. A condenser pressure of $4 \mathrm{in.} \mathrm{Hg}$ absolute (approximately 2 psia) was selected as the minimum practical condenser pressure based on the experience with barometric condensers at the Geysers geothermal plant in California. ${ }^{(44)}$ The environmental conditions selected for the single set of cooling tower operating conditions are shown below. One cannot use the annual average temperature for sizing cooling towers due to restrictions on power plant performance at warmer temperatures.

Average air temperature $-21^{\circ} \mathrm{C}\left(70^{\circ} \mathrm{F}\right)$

Relative humidity - $40 \%$

Corresponding wet bulb $-13^{\circ} \mathrm{C}\left(55^{\circ} \mathrm{F}\right)$

The 2 psia barometric condenser pressure lower limit sets the temperature of the condensing steam at $52^{\circ} \mathrm{C}\left(126^{\circ} \mathrm{F}\right)$ in a flashed steam cycle. The condensing temperature of the working fluid in a binary fluid cycle depends on cooling tower conditions and will typically be $40-50^{\circ} \mathrm{F}$ above the ambient wet bulb temperature. A steam condenser-cooling tower heat transfer dia$\operatorname{gram}^{(45 .)}$ is shown in Figure 4.16. 


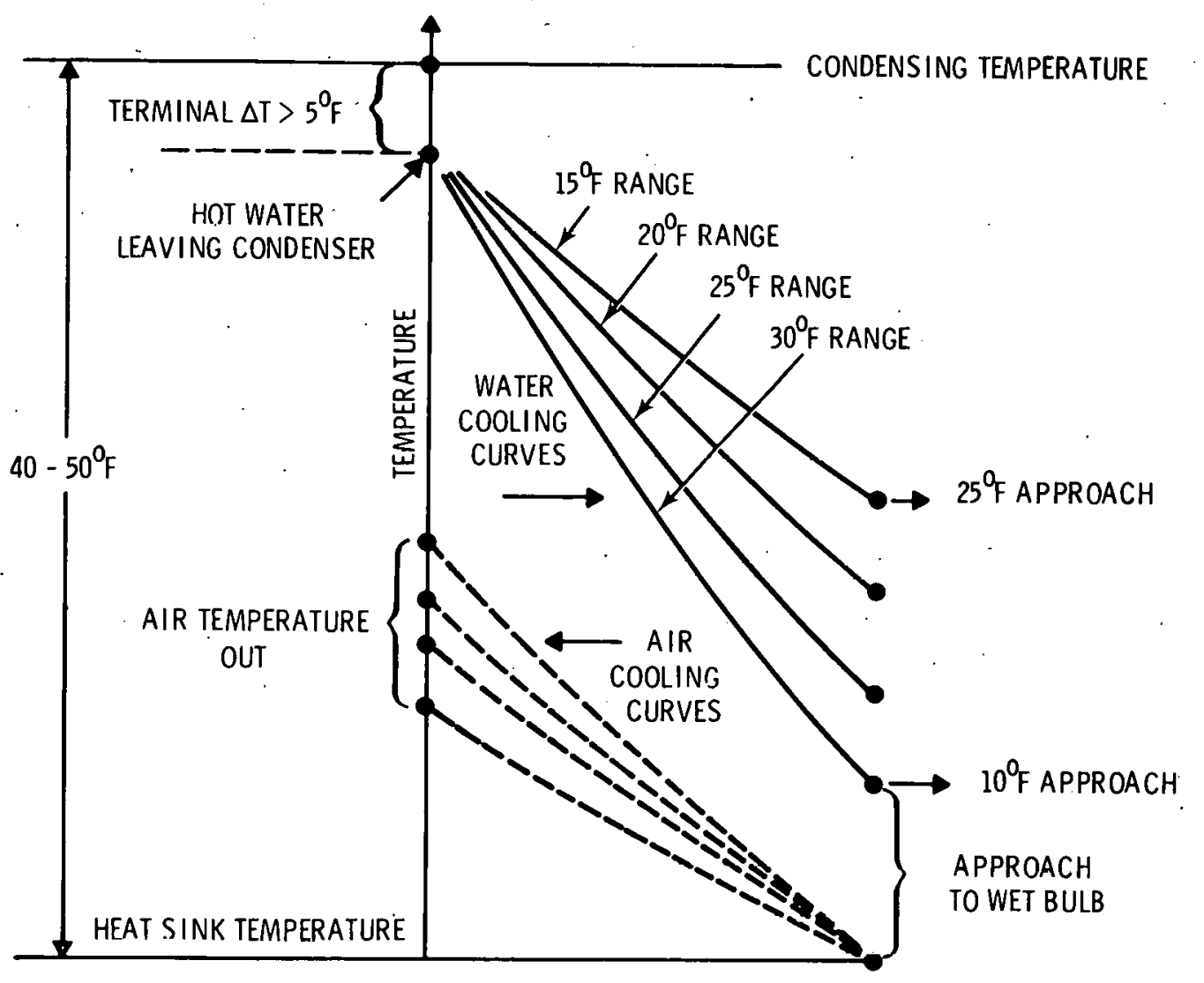

WET BULB TEMPERATURE $=55^{\circ} \mathrm{F}$

NOTE: HEAT EXCHANGER AREA DECREASES WITH INCREASING RANGE. PUMPING AND PIPING COSTS INCREASE WITH INCREASING RANGE.

FIGURE 4.16. Steam Condenser-Cooling Tower Heat Transfer Diagram 


\subsection{COST ESTIMATES}

\subsection{Pond Cost Estimates}

\subsubsection{Nonconvecting Pond Cost Estimates}

Capital cost estimates for nonconvecting ponds are summarized in Table 5.1. The cost estimate for the shallow pond is summarized in Table 5.2.

The bases for these estimates are dịscussed below:

Land Acquisition

One square mile, including $600 \mathrm{ft}$ at each side of pond.

$1 \mathrm{mi}^{2}=640$ acres

$640 \times \$ 500 /$ acre $=\$ 320,000$

Pond Earth Construction

Leveling

Patrol - $10 \mathrm{ft} /$ pass - $10 \mathrm{mi} / \mathrm{hr}$

$10 \mathrm{mi} /$ day -60 passes at $10 \mathrm{ft}=600 \mathrm{ft} /$ day $-\frac{4,000}{600}$

$=7$ days $\times 3=21$ days at $200=\$ 4,000$

Dike

3 yd high $x 6$ yd wide

$\times 1,400 \mathrm{yd} \times 4$ lengths $=100,800 \mathrm{yd}$

at $\$ 0.50 / y d=\$ 50,000$

Hypalon Liner

4,000 ft plus $20 \mathrm{ft}$ on each side

$4,040 \times 4,040=16.3 \times 10^{6} \mathrm{ft}^{2}$

Procurement

$16.3 \times 10^{6} \times 0.27=4,401,000$

Installation

$16.3 \times 10^{6} \times 0.08=1,304,000$

(includes concrete or other retainer) 
TABLE 5.1 Capital Cost Estimates, $10 \mathrm{MW}$ Nonconvecting Solar Ponds

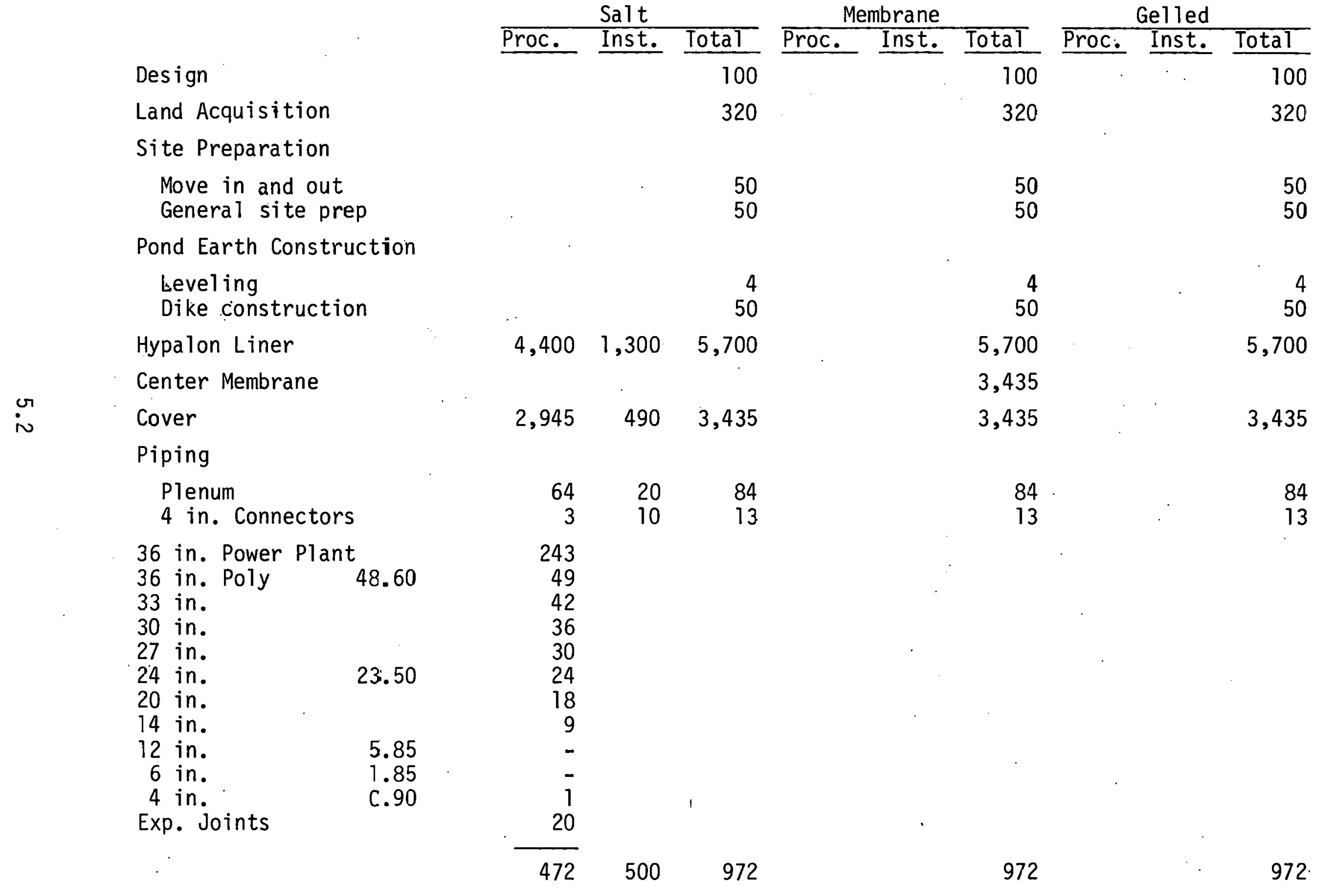


TABLE 5.1. (contd)

Insulation

$\frac{\text { Salt }}{\frac{\text { Membrane }}{50}} \frac{\text { Gelled }}{\text { Proc. }} \stackrel{\text { Inst. }}{\frac{\text { Inst. }}{50}} \frac{\text { Total }}{\text { Proc. }} \frac{\text { Inst. } \frac{\text { Total }}{50}}{\text { Proc. }}$

Pump Stations

(In GEOCOST)

Fresh Water Piping, Allow

100

200

100

i

Gel Reprocessing, Allow

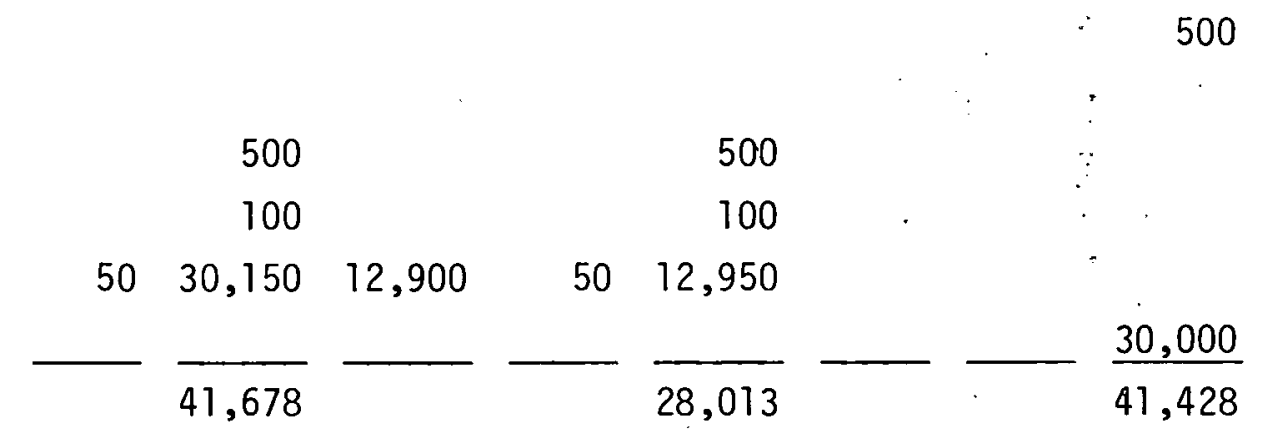

Desalination Equipment

Salt Injection Equipment, Allow

Salt, $\mathrm{MgCl}$

30,100

41,678

28,013

41,428 
TABLE 5.2. Capital Cost Estimate for Shallow Solar Pond

$\begin{array}{lr}\text { Design } & \begin{array}{r}\$ 1,000 \\ \text { Land Acquisition }\end{array} \\ \text { Pond } & 320 \\ \quad \text { Collectors } & 29,120 \\ \quad \text { Reservoir } & \frac{1,620}{\$ 31,160}\end{array}$

\section{Center Membrane}

Procurement

$$
16.3 \times 10^{6} \times 0.15=2,445,000
$$

$$
\begin{array}{cr}
\text { Floatation-Allowance } & 500,000 \\
& 2,945,000 \\
\text { Installation } & \\
16.3 \times 10^{6} \times 0.03 & 489,000
\end{array}
$$

Piping

Plenum

$$
8,000 \mathrm{ft} \text { a.t } \$ 8.00
$$

(based on $\$ 5.85 / \mathrm{ft}$ for 12 in. pipe)

$$
64,000
$$

4 in. connectors $50 \mathrm{ft}$ oc

$20 \mathrm{ft} \times 80 \times 2=3200 \mathrm{ft}$ at $\$ 0.90$

$$
2,880
$$

Dist. Pipe

4 in. $1,000 \times 0.90$

14 in. $1,000 \times 8.79$

8,790

20 in. $1,000 \times 17.61$

$1 /, 610$

24 in. $1,000 \times 23.50$

23,500

27 in. $1,000 \times 29.77$

29,770

30 in. $1,000 \times 36.04$

36,040

33 in. $1,000 \times 42.31$

42,310

36 in. $1,000 \times 48,60$

48,600

36 in. $5,000 \times 48.60$

243,000

$(5,000$ is for power house connections)

Exp Joints $20 \times 2=40 \times 500$ 
Salt

$\$ 11.00 /$ ton for $\mathrm{MgCl}_{2}$ in $28 \%$ solution in 100,000 ton quantity FOB Great Salt Lake - include shipping allowance and use $\$ 15.00$ per ton.

Salt pond

Use $25 \%$ in bottom $\mathrm{ft}$ and $25-0 \%$ in top $5 \mathrm{ft}$

Equivalent salt volume $=1+2.5=3.5 \mathrm{ft}$ deep

$3.5 \times 4,000 \times 4,000=56 \times 10^{6} \mathrm{ft}^{3}$ at $80 \mathrm{lb} / \mathrm{ft}^{3} \mathrm{wt}=4.5 \times 10^{9} \mathrm{lb}$

$=\frac{4.5 \times 10^{9}}{2 \times 10^{3}}=2.25 \times 10^{6}$ tons

$\cos t=2.25 \times 10^{6} \times \$ 15.00=33,750,000$

for $25 \% \frac{25}{28} \times 33.75=30.1$ million

SaTt - membrane pond

Use $\$ 15.00$ per ton for $28 \%$

Use $25 \%-0 \%$ in top $3 \mathrm{ft}$

Equivalent, $11 / 2 \mathrm{ft}$ at $25 \%$

$1.5 \times 4,000 \times 4,000 \mathrm{ft}^{3}$

$=24 \times 10^{6} \mathrm{ft}^{3}$

$801 \mathrm{~b} / \mathrm{ft} \times 24 \times 10^{6}$

$$
\begin{aligned}
& =1920 \times 10^{6}=1.92 \times 10^{9} \mathrm{lb} \\
& =\frac{1.92 \times 10^{9}}{2 \times 10^{3}}=0.96 \times 10^{6} \text { tons }
\end{aligned}
$$

at $\$ 15.00 / T=\$ 14.4 \mathrm{million}$

for $25 \%-25 / 28 \times 14.4=\$ 12.9$ million

Gelling Agent

Use, for reference pond, a synthetic polymer at $\$ 1.00 / 1 b$ and $1 \%$ concentration. 
$3 \mathrm{ft}$ thick

$$
\begin{array}{ll}
3 \times 4,000 \times 4,000=48 \times 10^{6} \mathrm{ft}^{3} & \\
\times 62.51 \mathrm{~b} / \mathrm{ft}^{3}=3,000 \times 10^{6} & \\
=3 \times 10^{9} 1 \mathrm{~b} & \\
0.01 \times 3 \times 10^{9}=3 \times 10^{7}= & \$ 30,000,000
\end{array}
$$

\subsubsection{Shallow Pond Cost Estimate}

Pond (from UCRL-51783) with a long life design; estimated component costs per $\mathrm{ft}^{2}$.

Site preparation

$\$ 0.10$

Moisture barrier 0.04

Bottom insulation 0.37

Water bag 0.25

Acry.lic panels 0.52

Curbing and mounts 0.33

Assembly hardware and installation 0.05

Piping and fittings 0.05

Pumps and motors 0.06

Instruments and controls

For a $16 \times 10^{6} \mathrm{ft}^{2}$ pond, this cost is:

$$
1.82 \times 16 \times 10^{6}=\$ 29.12 \text { million }
$$

For the reservoir cost, use the same volume as the storage half of the nonconvecting pond.

$$
3 \mathrm{ft} \times 16 \times 10^{6}=48 \times 10^{6} \mathrm{ft}^{3}
$$

For a pond $48 \mathrm{ft}$ deep, the surface area is:

$$
\frac{48 \times 10^{6} \mathrm{ft}^{2}}{48}=10^{6} \mathrm{ft}^{2}
$$

The pond is thus $1,000 \mathrm{ft}$ on a side.

The construction costs are estimated at: 
$\underline{\text { Dike }}$

$4,000 \mathrm{ft}=1,333 \mathrm{yd}$

x 20 yd high $x 30$ yd wide equivalent $=799,800$ yd

at $\$ 1.00 / y d-=$

$\$ 800,000$

Liner

Procurement:

$10^{6} \mathrm{ft} \times 0.27=\quad 270,000$

Installation:

$$
10^{6} \mathrm{ft}^{2} \times 0.08 \quad 80,000
$$

Insulation:

$$
10^{6} \mathrm{ft}^{2} \times 0.37 \quad 370,000
$$

Cover:

$$
\begin{array}{ll}
10^{6} \mathrm{ft}^{2} \times 0.10 & \frac{100,000}{\text { Total reservoir cost }} \$ 1,620,000
\end{array}
$$

\subsection{Pond Operating Cost Estimates}

\subsubsection{Pond Operating Costs}

Operation labor, $1 \mathrm{man} / \mathrm{sh}$ ift

Liner maintenance and replacement allowance

General maintenance allowance

Salt replacement allowance

$$
\begin{gathered}
\frac{\text { Annual Cost }}{\$ 40,000} \\
500,000 \\
40,000 \\
50,000 \\
\$ 630,000
\end{gathered}
$$

\subsubsection{Operating Cost Estimate - Shallow Solar Pond}

Use 3 years for 1 ife of water bag - at $\$ 0.25 / \mathrm{ft}$, replacement cost $\doteq$ $16 \times 10^{6} \times 0.25=\$ 4,000,000$ every 3 years

Assuming a continuous, stable level of replacement, this cost is $\$ 1,333,000 / y r$ : Estimated operating costs are:

$\begin{array}{lr}\text { Labor } & \$ 40,000 \\ \text { Maintenance } & 40,000 \\ \text { Replacement parts } & \frac{1,400,000}{} \\ & \$ 1,480,000 / \mathrm{yr}\end{array}$




\subsection{Power Plant Costs}

Power plant costs and power costs were estimated with GEOCOST and hand calculations. Results are summarized in Tables 5.3 and 5.4 and Figure 5.1.

In the costs given below, there is enough variation in each system that positions could be reversed.

The estimated cost of power ranges from $114.4 \mathrm{mills} / \mathrm{kW}-\mathrm{hr}$ for the membrane pond to $203.6 \mathrm{mills} / \mathrm{kW}-\mathrm{hr}$ for the nonconvecting salt pond on a flash steam cycle. If salt were free, a cost of $64.6 \mathrm{mills} / \mathrm{kW}-\mathrm{hr}$. might be achieved. Power costs are based on a duty cycle of 0.85 .

The GEOCOST model was developed at Battelle-Northwest to compute the costs associated with extracting geothermal resources from the earth and then using them to produce electricity. It has the capability of simulating the production of electricity from nearly any combination of resource type. and quality and plant design. It is particularly well suited for comparative analyses. This model has been adapted for this study to allow substitution of a solar pond for the geothermal reservoir. The costs of the reservoir were changed to allow for the different resource. The cost at the plant and other economic assumptions are unchanged. The plant is assumed to be operating with an $85 \%$. load factor.

Geothermal reservoir costs are separated into three categories: exploration, development and operation. The exploration costs include all those incurred searching for and securing a geothermal, site. These are set to zero for the solar pond case. The development costs are the well drilling costs plus the transmission and disposal systems construction costs. For this analys is the expense of the solar pond is substituted for that of a producing well and the fluid transmission costs are the same as for a geothermal field with one well. Operation costs for the solar pond begin the first year of power piant operation and are a constant annual expense for the 30-year life of the project. Included in this expense is an annual charge for replacing the pond cover every 7 years and the cost of makeup water. 
TABLE 5.3. $10 \mathrm{MW}_{\mathrm{e}}$ Solar Pond Concepts - Economic Summary

\begin{tabular}{|c|c|c|c|c|c|c|c|}
\hline & \multicolumn{2}{|c|}{ Nonconvecting } & \multirow[b]{2}{*}{ Membrane } & \multirow[b]{2}{*}{$\mathrm{Gel}$} & \multirow[b]{2}{*}{ Shallow } & \multirow{2}{*}{$\begin{array}{l}\text { Free* } \\
\text { Salt }\end{array}$} & \multirow{2}{*}{$\begin{array}{l}\text { Geothermal } \\
\text { Reference } \\
\end{array}$} \\
\hline & Steam & Binary & & & & & \\
\hline $\begin{array}{l}\text { Pond cost } \\
\left(\$ \times 10^{6}\right)\end{array}$ & 41.6 & 41.6 & 28.0 & 41.4 & 31.1 & 11.5 & 4.5 \\
\hline $\begin{array}{l}\text { Plant capital } \\
\text { cost }\left(\$ \times 10^{6}\right)\end{array}$ & 17.148 & 7.107 & 7.107 & 7.107 & 7.107 & 7.107 & 7.132 \\
\hline $\begin{array}{l}\text { Net power } \\
\text { output (MU) }\end{array}$ & 6.652 & 7.653 & 7.653 & 7.653 & 7.653 & 7.653 & 6.240 \\
\hline $\begin{array}{l}\text { Installed cost } \\
(\$ / \mathrm{k} \text { net })\end{array}$ & 8,690 & 6,366 & 4,588 & 6,339 & 4,993 & 2,236 . & 1,864 \\
\hline $\begin{array}{l}\text { Cost of power } \\
(\text { mil } 1 \mathrm{~s} / \mathrm{k} \text { W-hr) }\end{array}$ & 203.6 & 105.2 & 114.4 & 149.6 & 124.9 & 71.1 & 87.1 \\
\hline $\begin{array}{l}\text { *Free salt is } \\
\text { available at }\end{array}$ & $\begin{array}{l}\text { the case wh } \\
\text { no cost. }\end{array}$ & 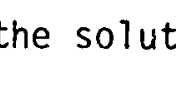 & $r t$ & cti & & id is & \\
\hline
\end{tabular}


TABLE 5.4. $10 \mathrm{MW}_{\mathrm{e}}$ Solar Pond Concepts - Thermodynamic Summary Plant Type Steam Plant Binary/Isobutane Plant

\begin{tabular}{|c|c|c|c|c|c|}
\hline Pond Operating Temp. & $90^{\circ} \mathrm{C}$ & $80^{\circ} \mathrm{C}$ & $90^{\circ} \mathrm{C}$ & $80^{\circ} \mathrm{C}$ & $70^{\circ} \mathrm{C}$ \\
\hline $\begin{array}{l}\text { Pond Flow Rate } \\
\left(10^{6} \mathrm{lb} / \mathrm{hr}\right)\end{array}$ & 28.1 & 54.5 & 23.6 & 33.1 & 50.3 \\
\hline $\begin{array}{l}\text { Make-Up Water Rate } \\
\left(10^{6} \mathrm{lb} / \mathrm{hr}\right)\end{array}$ & 0.794 & 1.130 & 0.326 & 0.403 & .555 \\
\hline $\begin{array}{l}\text { Net Heat Rate } \\
\left(10^{6} \mathrm{Btu} / \mathrm{kW}-\mathrm{hr}\right)\end{array}$ & 0.1429 & 0.2337 & 0.3490 & 0.4305 & 0.5776 \\
\hline $\begin{array}{l}\text { Net Power Output } \\
\text { (MW) }\end{array}$ & 6.652 & 4.882 & 7.653 & 7.151 & 6.143 \\
\hline $\begin{array}{l}\text { Plant Capital Cost } \\
\left(10^{6} \$\right)\end{array}$ & 17.148 & 21.478 & 7.107 & 8.109 & 10.039 \\
\hline Installed Cost & 8,690 & 12,348 & 6,366 & 6,866 & 8,404 \\
\hline
\end{tabular}
$(\$ / \mathrm{kW} \mathrm{Net})$

In treatment of the above reservoir costs two accounting methods were used which warrant discussion. In the geothermal case they are assumed to be reasonable as tax incentives to potential investors. This may not be an appropriate assumption in the solar pond system.

The first of these is dividing the producing well costs (here the solar pond cost) into tangible and intangible parts. The tangible portion is capitalized and recovered through a depreciation account. The intangible portion is treated as a tax deductible expense during the year incurred. This is patterned after the oil industry where the tax law allows a company to differentiate between that portion of well cost which is actually depreciable capital (tangible assets) and the other expenses associated with drilling of a well.

The second is the use of sum-of-the-year's-digits depreciation. This method, which is more accelerated than straight-line depreciation, can best be explained through the use of an example. If the depreciable life of an asset is 4 years, then the depreciation rate for those years will be as follows: 


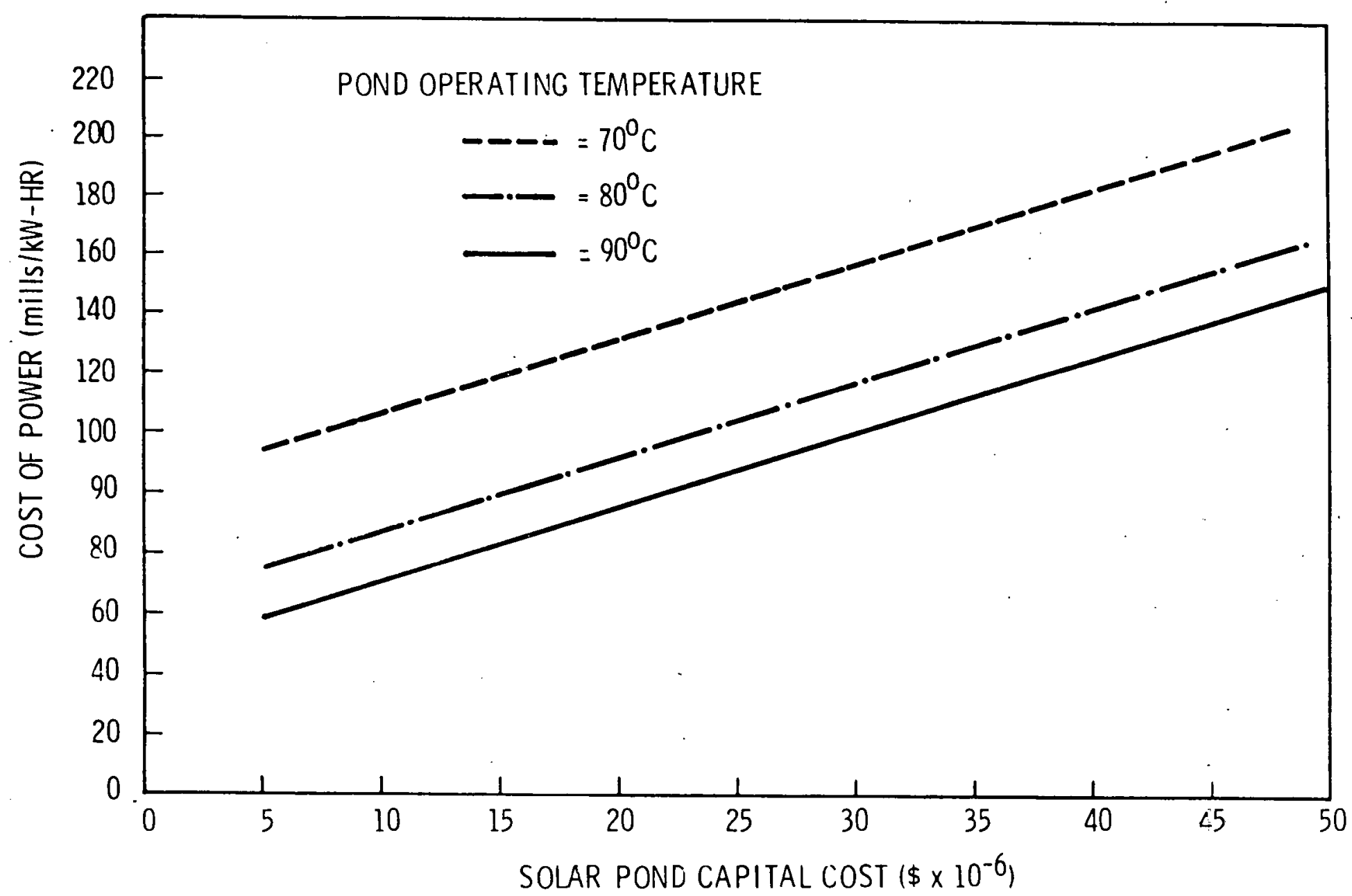

FIGURE 5.1. Solar Pond Electrical Power Generation - Cost of Power Versus Pond Cost (based on $10 \mathrm{MH}$ gross power plant binary/isobutane power cycle) 


$$
\begin{aligned}
4+3+2+1=10 \text { (Sum-of-the-Year's-Digits) } \\
\text { 1st year depreciation rate }=4 / 10 \\
\text { 2nd year depreciation rate }=3 / 10 \\
\text { 3rd year depreciation rate }=2 / 10 \\
\text { 4th year depreciation rate }=\frac{1 / 10}{10 / 10} .
\end{aligned}
$$

The capital equipment at the power plant is depreciated using the same method. The cost of the equipment and of operating the plant were obtained from both industry vendor data and utility operators. Annual plant expenses are comprised of four elements: operating costs $=\$ 1,455$ $\left(\text { plant size in } \mathrm{MW}_{\mathrm{e}}\right)^{0.9}$; maintenance $=0.004 \cdot($ plant capital in $\$)$; interim plant capital replacement $=0.035 \cdot$ (plant capital in $\$$ ); and property insurance and taxes and other taxes. The insurance and tax rates are shown below along with those for the reservoir.

Financing and Tax Assumptions

Reservoir
$(\%)$$\quad$ Power Plant

Capitalization

Debt

Equity

Bond Interest Rate

Return on Equity

Federal Income Tax

State Income Tax

Property Tax Rates

State Revenuc Tax

Property Insurance
42

58

8

15

48

7.

2.5

0.12
59

41

8

12

48

7

2.5

4

In general, the GEOCOST program solves for the unit cost of energy by equating the present worth of revenues and expenses over the useful life of the power plant. The program provides for incurring debt and equity at a specified ratio when expenses exceed revenues and repaying debt and equity in the same ratio when revenues exceed expenses. At the 
end of the project, debt and equity are exactly repaid and the project exactly earns the specified rate of return. Assumptions about tax, debtto-equity ratios and tax deductible expenses were made assuming a large oil company operating the reservoir and an investor-owned utility operating the power plant. The tax rates are a composite, typical of the western States.

The GEOCOST model does not apply a fixed charge rate to capital to determine the annual expenses associated with that capital. Instead it calculates each component separately. A fixed charge rate equivalent to the sum of the charges used in GEOCOST can be derived for comparison.

This is done below. The annual rates which went into the components of this fixed charge rate are given above in the list of financing and tax assumptions.

$\begin{array}{lc}\text { Total return on capital plus amortization } & 10.01 \% \\ \text { Interim capital replacements } & 0.35 \\ \text { Federal and state taxes } & 2.95 \\ \text { Property taxes and insurance } & \frac{2.61}{15.92 \%}\end{array}$

Total return on capital plus amortization includes the after-tax return on equity and bond interest. The amortization portion of this figure is that small fraction of plant capital which, when set aside each year at a rate equal to the return on capital, will yield a fund equal to the initial plant capital at the end of the project. Interim plant capital replacements are those which generally have to be made during each year of normal operation. State taxes include income and revenue taxes. The only federal tax included is income tax.

The total of $15.92 \%$ for fixed charges is higher than would be used in subsequent iterations. Fifteen percent is commonily used today and in some cases this might be as low as 12 to 13\%. While the use of a higher number tends to increase the calculated cost of power, it is a mild conservatism in the context of this report. 
The calculations below show the approximate power plant cost, based on the hand calculations of plant operating conditions. The bases for the costs are somewhat different than those calculated by GEOCOST.

Heat exchanger:

preheater

$38,000 \mathrm{ft}^{2}$

vaporizer

77,400

superheater

2,750

main condenser

$\underline{75,000}$

Total area $=$

$193,150 \mathrm{ft}^{2}$

at $\$ 12.00 / \mathrm{ft}^{2}$

$\$ 2,317,000$

Turbogenerator $\$ \$ 100 / \mathrm{kW}_{\mathrm{e}}$ installed

$1,000,000$

Auxiliary heat exchangers for turbine

oil coolers, etc., o $10 \%$ of total

HX area

200,000

Cooling tower o $\$ 75 / \mathrm{kW}_{\mathrm{e}}$ installed

750,000

Support equipment (crane, etc.)

500,000

Piping and pumps

200,000

Building and foundations

500,000

Electrical switch yard

300,000

Design

600,000

Administration

500,000

$\$ 6,867,000$

Parasitic pumping power losses:

Assume a pump efficiency of $85 \%$

$$
H P=\frac{Q \Delta p}{0.85}
$$

Pumping losses for the solar pond water were assumed to be limited primarily to pressure drops through heat exchangers. The total length of the preheater, vaporizer and superheater would be approximately $300 \mathrm{ft}$. Head loss due to pipe friction in the distribution system to and from the pond could be very small. 
For cooling water to cooling tower, assume a head loss of $45 \mathrm{ft}$.

$H P=Q_{C W} 45 \mathrm{ft}\left(0.4335 \frac{\mathrm{psi}}{\mathrm{ft}}\right)$

$H P=1.54 \times 10^{7} \frac{\mathrm{lb}}{\mathrm{hr}}\left(19.51 \frac{\mathrm{lb}}{\mathrm{in.}^{2}}\right) \frac{1}{3600 \frac{\mathrm{sec}}{\mathrm{hr}}}\left(62.4 \frac{\mathrm{lb}}{\mathrm{ft}^{3}}\right)$

$$
550 \frac{1}{\frac{\mathrm{ft} \cdot 1 \mathrm{~b}}{\mathrm{sec}}}\left(\frac{144 \mathrm{in.}^{2}}{\mathrm{ft}^{2}}\right)
$$

$H P=350.2$

Power consumption $=\frac{350.2 \mathrm{HP}}{0.85} \frac{0.746 \mathrm{~kW}}{\mathrm{HP}}=307 \mathrm{~kW}_{\mathrm{e}}$

Condenser cooling water:

Assume a pressure drop of $10 \mathrm{psi}$

$H P=Q_{C W}(10$ psi $)$

The pressure drop is approximately $1 / 2$ of the drop to the cooling tower

$\therefore$ power consumption $\approx 150 \mathrm{~kW}$

Cooling tower fan power requirements are typically $500 \mathrm{~kW}$ for the tower conditions assumed.

Isobutane pump requirements:

$H P=Q_{W f} \Delta_{p}=Q_{W f}\left(p_{1}-p_{2}\right)=Q_{W f}(185-69)$

$H P=\frac{2.68 \times 10^{6}(116)(144)}{3600(33.33)(550)}=678$

Power consumption $=\frac{678}{0.85}(0.746)=595 \mathrm{~kW}$

Solar pond water pumping requirements:

Assume a 30 psi total pressure drop through vaporizer, superheater and vaporizer. 


$$
\begin{aligned}
& H P=Q_{p w}(30) \\
& =\frac{3.04 \times 10^{7}(30)(144)}{3,600(78)(550)}=850 \\
& \text { Power consumption }=\frac{850}{0.85}(0.746)=746 \mathrm{~kW}_{\mathrm{e}} \\
& \text { Total parasitic power losses: } \\
& \text { Cooling tower fan } \\
& 500 \mathrm{~kW} \\
& \text { Cooling tower pump } \\
& 307 \\
& \text { Condenser cooling pump } \\
& 150 \\
& \text { Working fluid pump } \\
& 595 \\
& \text { Pond water pump } \\
& 746 \\
& 2,298 \mathrm{~kW} \text { or }
\end{aligned}
$$

Installed plant cost based on nẹt power output:

$$
=\frac{\$ 6,900,000}{(10-2.3) \times 1,000} \cong \$ 900 \text { per } \mathrm{kW} \text {. }
$$

The wet cooling tower operating conditions shown in Figure 5.2 were assumed for cost estimates.

The summary data for the cycle conditions run on the computer are shown in Tables 5.5 through 5.15.

\subsection{Thermal Energy Cost Estimate}

Using average U.S. insolation of 500,000 Btu/ft $\mathrm{t}^{2}$, with a pond cost (including pumps, heat exchangers, etc.) of $\$ 1.50 \mathrm{ft}^{2}, 15 \%$ fixed charges, and a collection and use efficiency of $25 \%$, the cost per million Btu is:

$$
\frac{\$ 1.50 / \mathrm{ft}^{2} \times 0.15 / \mathrm{yr}}{0.25 \mathrm{eff} \times 500,000 \mathrm{Btu} / \mathrm{ft}^{2} / \mathrm{hr}}=\$ 1.80 / 10^{6} \mathrm{Btu}
$$

Salt replacement and other operating costs would add to this. 


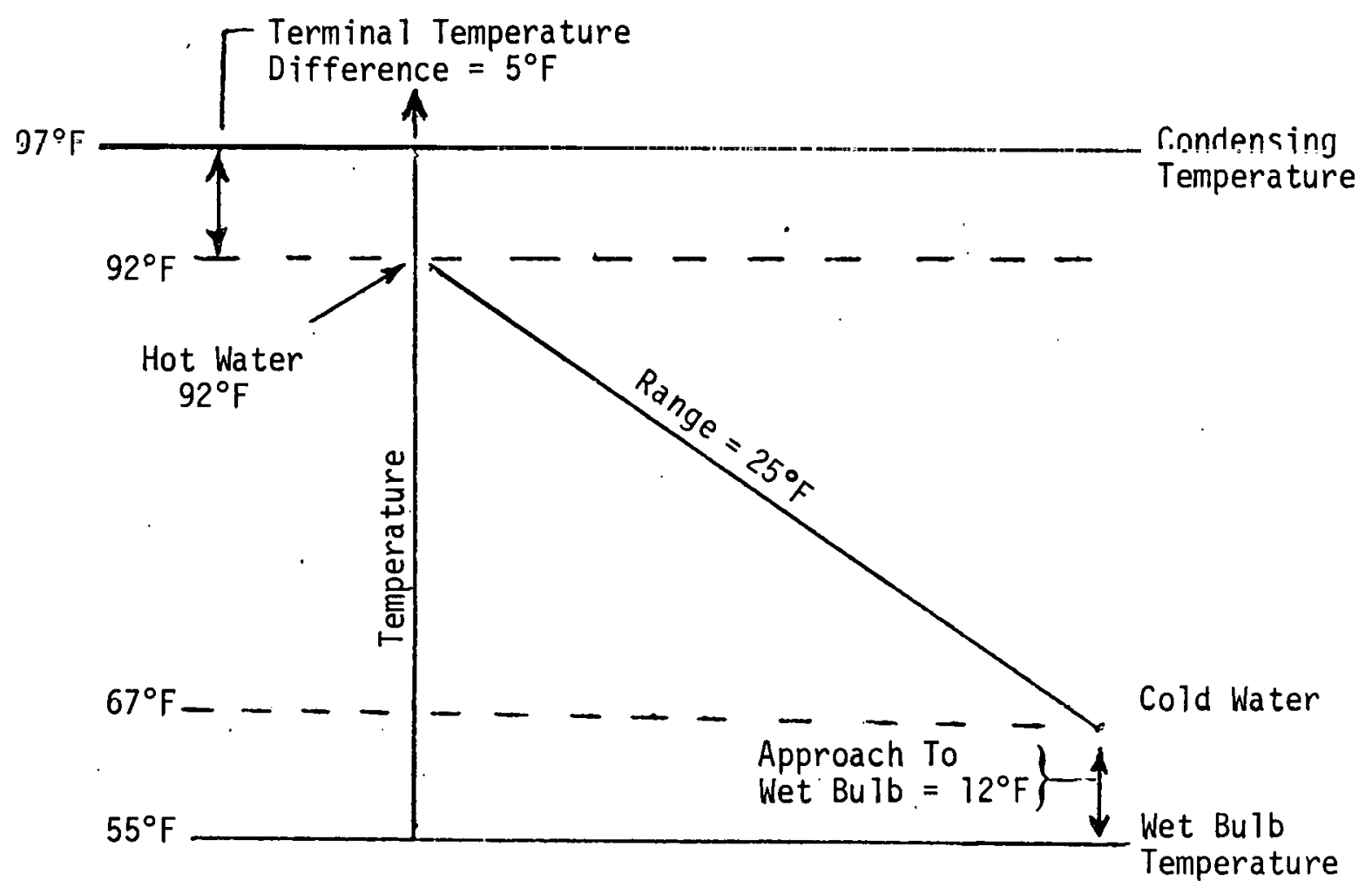

FIGURE 5.2. Wet Cooling Tower Operating Conditions Assumed 
TABLE 5.5. Comparative Evaluation of Solar Pond Concepts:

Nonconvecting Salt o $90^{\circ} \mathrm{C}$ - Binary Cycle

\section{INITIAL SYSTEM CONDITIONS}

Pond Operating Temperature: $90^{\circ} \mathrm{C}\left(194^{\circ} \mathrm{F}\right)$

Wet Bulb Temperature: $55^{\circ} \mathrm{F}$

Overall Turbine Efficiency: $273 \%$

Turbine Exhaust Pressure: 69 psia

Pressure Drop in Heat Exchangers: 10 psi

\section{OPERATING CONDITIONS}

Pond Water Flow Rate $(1 \mathrm{~b} / \mathrm{hr}): 2.36 \times 10^{7}$ Working Fluid Flow Rate $(1 \mathrm{~b} / \mathrm{hr}): 2.75 \times 10^{6}$ Cooling Water Flow Rate $(1 \mathrm{~b} / \mathrm{hr}): 1.65 \times 10^{7}$ Make-up Water for Cooling Tower $(1 \mathrm{~b} / \mathrm{hr}): 3.2 \times 10^{5}$ Net Power Output $\left(\mathrm{MW}_{\mathrm{e}}\right): 7.6 \mathrm{MW}_{\mathrm{e}}$

\section{POWER PLANT THERMODYNAMIC PERFORMANCE}

$\Delta t$ of Pond Water: $19^{\circ} \mathrm{F}$

$\because \quad$ Cooling Water Temperature: $67^{\circ} \mathrm{F}$

$\vec{\infty}$ Condensing Temperature: $97^{\circ} \mathrm{F}$

Net heat Rate (Btu/kW-hr): $3.49 \times 10^{5}$

Parasitic Power Losses

Cooling water: $1.0 \mathrm{MW}_{\mathrm{e}}$

Working fluid: $0.5 \mathrm{Mw}_{\mathrm{e}}=$

Pond water: $\quad 0.8 \mathrm{MW}_{\mathrm{e}}$
Heat Exchanger Parameters:

\begin{tabular}{lcll} 
& \multicolumn{1}{c}{ Areas } & & Overall U \\
\cline { 2 - 3 } Main Condenser & $50,500 \mathrm{ft}^{2}$ & & $264 \mathrm{Btu} / \mathrm{hr} / \mathrm{ft}^{2} /{ }^{\circ} \mathrm{F}$ \\
Preheater & 34,616 & 114 \\
Vaporizer & 76,230 & 258 \\
Superheater & 2,865 & 88 \\
Actual Rankine Efficiency (\%): & $7.63 \%$
\end{tabular}

\section{COST SUMMARY}

Power Plant Capital Cost: $\$ 7,100,000$ Pond Cost: $\$ 41,678,000$
Installed Cost Per Net kW Output: $\$ 6,366 / \mathrm{kW}_{\mathrm{e}}$ Energy Cost at Bus Bar: $150.2 \mathrm{mils} / \mathrm{kW}-\mathrm{hr}$ 
TABLE 5.6. Comparative Evaluation of Solar Pond Concepts:

Nonconvecting Salt @ $80^{\circ} \mathrm{C}$ - Binary Cycle

\section{INITIAL SYSTEM CONDITIONS}

Pond Operating Temperature: $80^{\circ} \mathrm{C}\left(176^{\circ} \mathrm{F}\right)$ Wet Bulb Temperature: $55^{\circ} \mathrm{F}$

Overall Turbine Efficiency: $~ 273 \%$

Turbine Exhaust Pressure: 69 psia

Pressure Drop in Heat Exchangers: 10 psi

\section{OPERATING CONDITIONS}

Pond Water Flow Rate $(1 \mathrm{~b} / \mathrm{hr}): 3.31 . \times 10^{7}$

Working Fluid Flow Rate $(1 \mathrm{~b} / \mathrm{hr}): 3.47 \times 10^{6}$

Cooling Water Flow Rate $(1 \mathrm{~b} / \mathrm{hr}): 2.04 \times 10^{7}$

Make-up Water for Cooling Tower $\left(1 \mathrm{~b} / \mathrm{h}_{\mathrm{r}}\right): 4.03 \times 10^{5}$

Net Power Output $\left(\mathrm{MW}_{\mathrm{e}}\right): 7.1 \mathrm{MW}_{\mathrm{e}}$

\section{POWER PLANT THERMODYNAMIC PERFORMANCE}

$\Delta t$ of Pond Water: $17^{\circ} \mathrm{F}$

$\because \quad$ Cooling Water Temperature: $67^{\circ} \mathrm{F}$

$\overrightarrow{0} \quad$ Condensing Temperature: $97^{\circ} \mathrm{F}$

Net Heat Rate (Btu/kW-hr): $4.3 \times 10^{5}$

Parasitic Power Losses

Cooling water: $1.3 \mathrm{MW}$

Working fluid: $0.5 \mathrm{MW}_{\mathrm{e}}$

Pond water: $\quad 1.1 \mathrm{MW}_{\mathrm{e}}$
Heat Exchanger Parameters:

\begin{tabular}{lcrl} 
& Areas & & Overall U \\
\cline { 2 - 3 } Main Condenser & $69,900 \mathrm{ft}^{2}$ & & $264 \mathrm{Btu} / \mathrm{hr} / \mathrm{ft}^{2} /{ }^{\circ} \mathrm{F}$ \\
Preheater & 40,100 & 108 \\
Vaporizer & 104,000 & 257 \\
Superheater & 3,060 & 81 \\
Actual Rankine Efficiency $(\%):$ & $6.26 \%$
\end{tabular}

\section{COST SUMMARY}

Power Plant Capital Cost: $\$ 8,109,000$

Pond Cost: $\$ 41,678,000$

Energy Cost at Bus Bar: $166.8 \mathrm{mils} / \mathrm{kW}-\mathrm{hr}$ 
TABLE 5.7. Comparative Evaluation of Solar Pond Concepts: Nonconvecting Salt a $70^{\circ} \mathrm{C}$ - Binary Cycle

\section{INITIAL SYSTEM CONDITIONS}

Pond Operating Temperature: $70^{\circ} \mathrm{C}\left(158^{\circ} \mathrm{F}\right)$

Wet Bulb Temperature: $55^{\circ} \mathrm{F}$

Overall Turbine Efficiency: $2.73 \%$

Turbine Exhaust Pressure: 69 psia

Pressure Drop in Heat Exichangers: 10 psi

\section{OPERATING CONDITIONS}

Pond Water Flow Rate $(1 \mathrm{~b} / \mathrm{hr}): 5.03 \times 10^{7}$ Working Fluid Flow Rate $(1 \mathrm{~b} / \mathrm{hr}): 4.88 \times 10^{6}$ Cooling Water Flow Rate (1b/hr): $2.82 \times 10^{7}$ Make-up Water for Cooling Tower $(1 \mathrm{~b} / \mathrm{hr}): 5.6 \times 10^{5}$ Net Power Output $\left(\mathrm{MW}_{\mathrm{e}}\right): 6.1 \mathrm{MW}_{\mathrm{e}}$

\section{POWER PLANT THERMODYNAMIC PERFORMANCE}

$\Delta \mathrm{t}$ of Pond Water: $15^{\circ} \mathrm{F}$

o Cooling Water Temperature: $67^{\circ} \mathrm{F}$

ㅇ Condensing Temperature: $97^{\circ} \mathrm{F}$

Net Heat Rate (Btu/kW-hr): $5.8 \times 10^{5}$

Parasitic Power Losses

Cooling water: $1.7 \mathrm{Mli}$

Working fluid: $0.5 \mathrm{MH}_{\mathrm{e}}$

Pond water: $\quad 1.6 \mathrm{M}$

Power Plant Capital Cost: $\$ 10,040,000$

Pond Cost: $\$ 41,678,000$
Heat Exchanger Parameters:

$\begin{array}{lccc} & \frac{\text { Areas }}{} & & \text { Overall U } \\ \text { Main Condenser } & 110,000 \mathrm{ft}^{2} & & 264 \mathrm{Btu} / \mathrm{hr} / \mathrm{ft}^{2} /{ }^{\circ} \mathrm{F} \\ \text { Preheater } & 48,200 & 104 \\ \text { Vaporizer } & 154,300 & 259 \\ \text { Superheater } & 3,800 & 76 \\ \text { Actual Rankine Efficiency }(\%): & 4.6 \%\end{array}$

\section{COST SUMMARY.}

Installed Cost Per Net k'N Output: $\$ 8,404 / \mathrm{kW}_{\mathrm{e}}$ Energy Cost at Bus Bar: $206.5 \mathrm{mils} / \mathrm{kW}-\mathrm{hr}$ 
TABLE 5.8. Comparative Evaluation of Solar Pond Concepts:

Nonconvecting Salt o $90^{\circ} \mathrm{C}$ - Flashed Steam Cycle

\section{INITIAL SYSTEM CONDITIONS}

Pond Operating Temperature: $90^{\circ} \mathrm{C}\left(194^{\circ} \mathrm{F}\right)$

Wet Bulb Temperature: $55^{\circ} \mathrm{F}$

Overall Turbine Efficiency: $78 \%$ *

Turbine Exhaust Pressure: $\sim 2$ psia

Pressure Drop in Heat Exchangers: 10 psi

\section{OPERATING CONDITIONS}

Pond Water Flow Rate $(1 \mathrm{~b} / \mathrm{hr}): 2.81 \times 10^{7}$ Working Fluid Flow Rate $(1 \mathrm{~b} / \mathrm{hr}):=9.57 \times 10^{5}$ (steam) Cooling Water Flow Rate $(1 \mathrm{~b} / \mathrm{hr}): 2.49 \times 10^{7}$

Make-up Water for Cooling. Tower $(1 \mathrm{~b} / \mathrm{hr}): 7.9 \times 10^{5}$ Net Power Output $\left(\mathrm{MW}_{\mathrm{e}}\right): 6.6 \mathrm{MW}_{\mathrm{e}}$

\section{POWER PLANT THERMODYNAMIC PERFORMANCE}

$\Delta \mathrm{t}$ of Pond Water: $34^{\circ} \mathrm{F}$

or Cooling Water Temperature: $67^{\circ} \mathrm{F}$

$\simeq$ Condensing Temperature: $97^{\circ} \mathrm{F}$

Parasitic Power Losses

Cooling water: $1.38 \mathrm{MW}_{\mathrm{e}}$ Net Heat Rate (Btu/kW-hr): $1.42 \times 10^{5}$

Working fluid: ?

Pond water: $\quad 0.92 \mathrm{MW}_{\mathrm{e}}$

Heat Exchanger Parameters:

Main Condenser
Preheater
Vaporizer
Superheater
Actual Rankine Efficiency (\%):

COST SUMMARY

Power Plant Capital Cost: $\$ 17,148,000$

Pond Cost: $\$ 41,678,000$

Installed Cost Per Net kW Output: $\$ \varepsilon, 690 / \mathrm{kW}_{\mathrm{e}}$ Energy Cost at Bus Bar: $203.6 \mathrm{mils} / \mathrm{kW}-\mathrm{hr}$

* The turbine efficiency assumed in the GEOCOST computer program is typical of turbines operating at pressures above those available from solar pond steam. 


\section{INITIAL SYSTEM CONDITIONS}

Pond Operating Temperature: $80^{\circ} \mathrm{C}\left(176^{\circ} \mathrm{F}\right)$

Wet Bulb Temperature: $55^{\circ} \mathrm{F}$

Overall Turbine Efficiency: 278\%*

Turbine Exhaust Pressure: $\sim 2$ psia

Pressure Drop in Heat Exchangers: 10 psi

\section{OPERATING CONDITIONS}

Pond Water Flow Rate (1b/hr): $5.4 \times 10^{7}$ Working Fluid Flow Rate $(1 \mathrm{~b} / \mathrm{hr}): 1.4 \times 10^{6}$

Cooling Water Flow Rate $(1 \mathrm{~b} / \mathrm{hr}): 3.6 \times 10^{7}$

Make-up Water for Cooling. Tower $(1 \mathrm{~b} / \mathrm{hr}): 1.13 \times 10^{6}$

Net Power Output $\left(\mathrm{MW}_{\mathrm{e}}\right): 4.9 \mathrm{MW}_{\mathrm{e}}$

\section{POWER PLANT THERMODYNAMIC PERFORMANCE}

$\Delta t$ of Pond Water: $25^{\circ} \mathrm{F}$

or Cooling Water Temperaturz: $67^{\circ} \mathrm{F}$

N Condensing Temperature: $97^{\circ} \mathrm{F}$

Net Heat Rate $(B t u / k W-h r): 2.3 \times 10^{5}$

Parasitic Power Losses

Cooling water: $3.4 \mathrm{MW}_{\mathrm{e}}$

Working fluid:

Pond water: $\quad 1.6 \mathrm{MH}_{\mathrm{e}}$
Heat Exchanger Parameters:

Main Condenser
Preheater
Vaporizer
Superheater
Actual Rankine Efficiency $(\%)$ :

\section{COST SUMMARY}

Power Plant Capital Cost: $\$ 21,478,000$

Pond Cost: $\$ 41,678,000$
Installed Cost Per Net kW Output: $\$ 12,348 / \mathrm{kW}_{\mathrm{e}}$

Energy Cost at Bus Bar: $238.3 \mathrm{mils} / \mathrm{kW}-\mathrm{hr}$

* The turbine efficiency assumed in the GEOCOST computer program is typical of turbines operating at pressures above those available from solar pond steam. 
TABLE 5.10. Comparative Evaluation of Solar Pond Concepts:

Membrane a $90^{\circ} \mathrm{C}$ - Binary Cycle

\section{INITIAL SYSTEM CONDITIONS}

Pond Operating Temperature: $90^{\circ} \mathrm{C}\left(194^{\circ} \mathrm{F}\right)$

Wet Bulb Temperature: $55^{\circ} \mathrm{F}$

Overall Turbine Efficiency: $273 \%$

Turbine Exhaust Pressure: 69 psia

Pressure Drop in Heat Exchangers: 10 psi

\section{OPERATING CONDITIONS}

Pond Water Flow Rate $(1 \mathrm{~b} / \mathrm{hr}): 2.4 \times 10^{7}$

Working Fluid Flow Rate $(1 \mathrm{~b} / \mathrm{hr}): 2.8 \times 10^{6}$

Cooling water Flow Rate $(1 \mathrm{~b} / \mathrm{hr}): 1.7 \times 10^{7}$

Make-up Water for Cooling Tower (1b/hr): $3.3 \times 10^{5}$

Net Power Output $\left(\mathrm{MW}_{\mathrm{e}}\right): 7.6 \mathrm{MW}_{\mathrm{e}}$

\section{POWER PLANT THERMODYNAMIC PERFORMANCE}

$\Delta \mathrm{t}$ of Pond Water: $29^{\circ} \mathrm{F}$

G

w

Cooling Water Temperature: $67^{\circ} \mathrm{F}$

Condensing Temperature: $97^{\circ} \mathrm{F}$

Net Heat Rate (Btu/kW-hr): $3.5 \times 10^{5}$

Parasitic Power Losses

Cooling water: $1.0 \mathrm{MWe}$

Working fluid: $0.6 \mathrm{MWe}_{\mathrm{e}}$

Pond water: $\quad 0.8 \mathrm{MW}_{\mathrm{e}}$
Heat Exchanger Parameters:

\begin{tabular}{lcc} 
& \multicolumn{1}{c}{ Areas } & Overall $\mathrm{U}$ \\
${$\cline { 2 - 3 }$} }$ & $50,500 \mathrm{ft}^{2}$ & $264 \mathrm{Btu} / \mathrm{hr} / \mathrm{ft}^{2} /{ }^{\circ} \mathrm{F}$ \\
Preheater & 34,600 & 114 \\
Vaporizer & 76,230 & 258 \\
Superheater & 2,870 & 88
\end{tabular}

Actual Rankine Efficiency (\%): $7.6 \%$
Power Plant Capital Cost: $\$ 7,107,000$ Pond Cost: $\$ 28,013,000$

\section{COST SUMMARY}

Installed Cost Per Net kW Output: $\$ 4,538 / \mathrm{kW}_{\mathrm{e}}$ Energy Cost at Bus Bar: $114.4 \mathrm{mi} / \mathrm{s} / \mathrm{kW}-\mathrm{ir}$ 
TABLE 5.11. Comparative Evaluation of Solar Pond Concepts:

Gel o $90^{\circ} \mathrm{C}$ - Binary Cycle

\section{INITIAL SYSTEM CONDITIONS}

Pond Operating Temperature: $90^{\circ} \mathrm{C}\left(194^{\circ} \mathrm{F}\right)$

Wet Bulb Temperature: $55^{\circ} \mathrm{F}$

Overall Turbine Efficiency: $\sim 73 \%$

Turbine Exhaust Pressure: 69 psia

Pressure Drop in Heat Ex:hangers: 10 psi
OPERATING CONDITIONS

Pond Water Flow Rate $(\mathrm{lb} / \mathrm{hr}): 2.36 \times 10^{7}$

Working Fluid Flow Rate $(1 \mathrm{~b} / \mathrm{hr}): 2.75 \times 10^{6}$

Cooling Water Flow Rate $(1 \mathrm{~b} / \mathrm{hr}): 1.65 \times 10^{7}$

Make-up Water for Cooling Tower $(1 \mathrm{~b} / \mathrm{hr}): 3.2 \times 10^{5}$ Net Power Output $\left(\mathrm{MW}_{\mathrm{e}}\right): 7.6 \mathrm{MW}_{\mathrm{e}}$

\section{POWER PLANT THERMODYNAMIC PERFORMANCE}

$\Delta t$ of Pond Water: $19^{\circ} \mathrm{F}$

or Cooling Water Temperature: $67^{\circ} \mathrm{F}$

\& Condensing Temperature: $97^{\circ} \mathrm{F}$

Net Heat Rate (Btu/kW-hr): $3.49 \times 10^{5}$

Parasitic Power Losses

Cooling water: $1.0 \mathrm{MW}_{\mathbf{e}}$

Working fluid: $0.5 \mathrm{MW}_{\mathrm{e}}$

Pond water: $\quad 0.8 \mathrm{MW}_{\mathrm{e}}$
Heat Exchanger Parameters:

\begin{tabular}{|c|c|c|}
\hline & Areas & Overall U \\
\hline Main Condenser & $50,500 \mathrm{ft}^{2}$ & $264 \mathrm{Btu} / \mathrm{hr} / \mathrm{ft}^{2} /{ }^{\circ} \mathrm{F}$ \\
\hline Preheater & 34,616 & 114 \\
\hline Vaporizer & 76,230 & 258 \\
\hline Superheater & 2,865 & 88 \\
\hline
\end{tabular}

Actual Rankine Efficiency (\%): $7.63 \%$
Power Plant Capital Cost: $\$ 7,100,000$

Pond Cost: $\$ 41,428,000$

\section{COST SUMMARY}

Installed Cost Per Net kW Output: $\$ 6,339 / \mathrm{kW}_{\mathrm{e}}$ Energy Cost at Bus Bar: $149.6 \mathrm{mils} / \mathrm{kW}-\mathrm{hr}$ 
TABLE 5.12. Comparative Evaluation of Solar Pond Concepts:

Shallow Pond $090^{\circ} \mathrm{C}$ - Binary Cycle

\section{INITIAL SYSTEM CONDITIONS}

Pond Operating Temperature: $90^{\circ} \mathrm{C}\left(194^{\circ} \mathrm{F}\right)$

Wet Bulb Temperature: $55^{\circ} \mathrm{F}$

Overall Turbine Efficiency: $~ \imath 73 \%$

Turbine Exhaust Pressure: 69 psia

Pressure Drop in Heat Exchangers: 10 psi
OPERATING CONDITIONS

Pond Water Flow Rate $(1 \mathrm{~b} / \mathrm{hr}): 2.4 \times 10^{7}$

Working Fluid Flow Rate $(1 \mathrm{~b} / \mathrm{hr}): 2.3 \times 10^{6}$

Cooling Water Flow Rate $(1 \mathrm{~b} / \mathrm{hr}): 1.7 \times 10^{7}$

Make-up Water for Cooling Tower $(1 \mathrm{~b} / \mathrm{hr}): 3.3 \times 10^{5}$

Net Power Output $\left(\mathrm{MW}_{\mathrm{e}}\right): 7.6 \mathrm{MW}_{\mathrm{e}}$

\section{POWER PLANT THERMODYNAMIC PERFORMANCE}

$\Delta t$ of Pond Water: $29^{\circ} \mathrm{F}$

or Cooling Water Temperature: $67^{\circ} \mathrm{F}$

जิ Condensing Temperature: $97^{\circ} \mathrm{F}$

Net Heat Rate (Btu/kW-hr): $3.5 \times 10^{5}$

Parasitic Power Losses

Cooling water: $1.0 \mathrm{MW}_{\mathrm{e}}$

Working fluid: $0.6 \mathrm{MW}_{\mathrm{e}}$

Pond water: $0.8 \mathrm{MW}_{\mathrm{e}}$
Heat Exchanger Parameters:

\begin{tabular}{lcll} 
& \multicolumn{1}{c}{ Areas } & & Overall U \\
\cline { 2 - 3 } Main Condenser & $50,500 \mathrm{ft}^{2}$ & & 264 Btu/hr $/ \mathrm{ft}^{2} /{ }^{\circ} \mathrm{F}$ \\
Preheater & 34,600 & 114 \\
Vaporizer & 76,230 & 258 \\
Superheater & 2,870 & 88 \\
Actual Rankine Efficiency (\%): & $7.6 \%$
\end{tabular}

\section{COST SUMMARY}

Power Plant Capital Cost: $\$ 7,107,000$

Pond Cost: $\$ 31,160,000$
Installed Cost Per Net kW Output: $\$ 4,993 / \mathrm{kW}_{\mathrm{e}}$

Energy Cost at Bus Bar: $124.9 \mathrm{mils} / \mathrm{kW}-\mathrm{hr}$ 
TABLE 5.13. Comparative Evaluation of Solar Pond Concepts: Nonconvecting Salt (Free Salt) o $90^{\circ} \mathrm{C}$ - Binary Cycle

\section{INITIAL SYSTEM CONDITIONS}

Pond Operating Temperature: $90^{\circ} \mathrm{C}\left(194^{\circ} \mathrm{F}\right)$

Wet Bulb Temperature: $55^{\circ} \mathrm{F}$

Overall Turbine Efficiency: $273 \%$

Turbine Exhaust. Pressure: 69 psia

Pressure Drop in Heat Exchangers: 10 psi

\section{OPERATING CONDITIONS}

Pond Water Flow Rate $(1 \mathrm{~b} / \mathrm{hr}): 2.4 \times 10^{7}$

Working Fluid Flow Rate $(1 \mathrm{~b} / \mathrm{hr}): 2.8 \times 10^{6}$

Cooling water Flow Rate $(1 \mathrm{~b} / \mathrm{hr}): 1.7 \times 10^{7}$

Make-up Water for Cooling Tower $(1 \mathrm{~b} / \mathrm{hr}): 3.3 \times 10^{5}$

Net Power Output $\left(\mathrm{MW}_{\mathrm{e}}\right): 7.6 \mathrm{MW}_{\mathrm{e}}$

\section{POWER PLANT THERMODYNAMIC PERFORMANCE}

$\Delta t$ of Pond Water: $19^{\circ} \mathrm{F}$

or Cooling Water Temperature: $67^{\circ} \mathrm{F}$

\% Condensing Temperature: $97^{\circ} \mathrm{F}$

Net Heat Rate $(B t u / k W-h r): 3.5 \times 10^{5}$

Parasitic Power Losses

Cooling water: $1.0 \mathrm{MW}_{\mathrm{e}}$

Working fluid: $0.6 \mathrm{MW}_{\mathrm{e}}$

Pond water: $\quad 0.8 \mathrm{MW}_{\mathrm{e}}$
Heat Exchanger Parameters:

Main Condenser $\frac{\text { Areas }}{50,500 \mathrm{ft}^{2}} \frac{\text { Overall U }}{264 \mathrm{Btu} / \mathrm{hr} / \mathrm{ft}^{2} /{ }^{\circ} \mathrm{F}}$

Preheater $34,600.114$

Vaporizer $\quad 76,200 \quad 258$

Superheater $\quad 2,860 \quad 88$

Actual Rankine Efficiency (\%): $7.63 \%$

\section{COST SUMMARY.}

Power Plant Capital Cost: $\$ 7,100,000$

Pond Cost: $\$ 11,528,000$
Installed Cost Per Net kW Output: $\$ 2,236 / \mathrm{kW}_{\mathrm{e}}$

Energy Cost at Bus Bar: $71.1 \mathrm{mils} / \mathrm{kW}-\mathrm{hr}$ 
TABLE 5.14. Comparative Evaluation of Solar Pond Concepts: Geothermal Reference Plant ${ }^{\circ} 177^{\circ} \mathrm{C}$ - Binary Cycle

\section{INITIAL SYSTEM CONDITIONS}

Pond Operating Temperature: $177^{\circ} \mathrm{C}\left(350^{\circ} \mathrm{F}\right)$

Wet Bulb Temperature: $50^{\circ} \mathrm{F}$

Overal1 Turbine Efficiency: $\sim 73 \%$

Turbine Exhaust Pressure: 260 psia

Pressure Drop in Heat Exchangers: 10 psi

\section{OPERATING CONDITIONS}

Pond Water Flow Rate $(1 \mathrm{~b} / \mathrm{hr}): 3.6 \times 10^{6}$ Working Fluid Flow Rate $(1 \mathrm{~b} / \mathrm{hr}): 3.2 \times 10^{6}$ Cooling Water Flow Rate $(1 \mathrm{~b} / \mathrm{hr}): 2.4 \times 10^{7}$ Make-up Water for Cooling Tower (1b/hr): $5.2 \times 10^{5}$ Net Power Output $\left(\mathrm{MW}_{\mathrm{e}}\right): 6.3 \mathrm{MW}_{\mathrm{e}}$

\section{POWER PLANT THERMODYNAMIC PERFORMANCE}

$\Delta t$ of Geoth. Water: $173^{\circ} \mathrm{F}$

or Cooling Water Temperature: $67^{\circ} \mathrm{F}$

i Condensing Temperature: $97^{\circ} \mathrm{F}$ Net Heat Rate $(B t u / k W-h r): 1.6 \times 10^{5}$ Parasitic Power Losses: $3.7 \mathrm{MW}_{\mathrm{e}}$ total* Cooling water: Working fluid: Pond water:

Power Plant Capital Cost: $\$ 7,130,000$ Pond Cost: ** $\$ 4,500,000$
Heat Exchanger Parameters:

\begin{tabular}{lll} 
Main Condenser & \multicolumn{1}{c}{ Areas } & Overall U \\
Preheater & $250 \cdot \mathrm{Btu} / \mathrm{hr} / \mathrm{ft}^{2} /{ }^{\circ} \mathrm{F}$ \\
Vaporizer & 329 \\
Superheater & 245 \\
Actual Rankine Efficiency (\%): & $5.4 \%$
\end{tabular}

Installed Cost Per Net kW Output: $\$ \bar{i}, 854 / \mathrm{kW}_{\mathrm{e}}$ Energy Cost at Bus Bar: $87 \mathrm{mils} / \mathrm{kW}-\mathrm{hr}$

* The parasitic power losses include a deep-well pump.

..... The pond in this case is geothermal reservoir development. 
TABLE 5.15. Comparative Evaluation of Solar Pond Concepts: Nonconvecting Salt a $90^{\circ} \mathrm{C}$ - Binary Cycle Hand Calculations

\section{INITIAL SYSTEM CONDITIONS}

Pond Operating Temperature: $90^{\circ} \mathrm{C}\left(194^{\circ} \mathrm{F}\right)$ Wet Bulb Temperature: $55^{\circ} \mathrm{F}$

Overall Turbine Efficiency: $275 \%$

Turbine Exhaust Pressure: 69 psia

Pressure Drop in Heat Exchangers: 10 psi

\section{OPERATING CONDITIONS}

Pond Water Flow Rate $(1 \mathrm{~b} / \mathrm{hr}): 3.0 \times 10^{7}$ Working Fluid Flow Rate $(1 \mathrm{~b} / \mathrm{hr}): 2.7 \times 10^{6}$ Cooling Water Flow Rate $(1 \mathrm{~b} / \mathrm{hr}): 1.5 \times 10^{7}$ Make-up Water for Cooling. Tower (1b/hr): Net Power Output $\left(\mathrm{MW}_{\mathrm{e}}\right): 7.7 \mathrm{MW}_{\mathrm{e}}$

\section{POWER PLANT. THERMODYNAMIC PERFORMANCE}

$\Delta \mathrm{t}$ of Pond Water: $16^{\circ} \mathrm{F}$

or Cooling Water Temperature: $67^{\circ} \mathrm{F}$

i Condensing Temperature: $97^{\circ} \mathrm{F}$

Net Heat Rate (Btu/kW-hr):

Pàrasitic Power Losses

Cooling water: $1.7 \mathrm{MW}_{\mathrm{e}}$ Working fluid: $0.5 \mathrm{MW}_{\mathrm{e}}$

Pond water: $\quad 0.7 \mathrm{MW}_{\mathrm{e}}$

Power Plant Capital Cost: $\$ 6,900,000$ Pond Cost:

* Power plant only.
Heat Exchanger Parameters:

\begin{tabular}{|c|c|c|}
\hline & Areas & Overall U \\
\hline Main Condenser & $75,000 \mathrm{ft}^{2}$ & $250 \mathrm{Btu} / \mathrm{hr} / \mathrm{ft}^{2} /{ }^{\circ} \mathrm{F}$ \\
\hline Preheater & 38,000 & 100 \\
\hline Vaporizer & 77,400 & 250 \\
\hline Superheater & 2,750 & 100 \\
\hline
\end{tabular}

Actual Rankine Efficiency (\%): 10.8\%

\section{COST SUMMARY.}

Installed Cost Per Net kW Output: $\$ 900 / \mathrm{kW}_{\mathrm{e}}$

Energy Cost at Bus Bar: 


\subsection{POSSIBLE PROBLEMS}

A number of factors (some previously mentioned) that could detract from the desirability of solar ponds include:

\section{Biological Degradation}

This study has not considered the probable need to add chemicals or other means of preventing the growth of algae, plants, etc. This one problem alone could make solar ponds impractical.

\section{Debris}

No mechanism is included in estimates for removal of debris from ponds. One concept which evolved from this analysis is the utilization of a moving wheel like the very large circle irrigators. A circle irrigator can currently be installed for $\$ 30,000$ which will water an area of 130 acres. This is less than $\$ 0.01 / \mathrm{ft}^{2}$. A similar mechanism, with screens attached, which would move once a week through the pond removing particulate debris might be possible.

\section{Weather}

This study does not consider provisions for the effects of wind and rain, other than the inclusion of a pond cover. Practical problems with a cover on a pond of the size discussed are unknown. It might be desirable to break the pond into a number of small ponds with dikes high enough to minimize the wind effects.

\section{Security Fence}

A fence to keep out animals, children and large debris might be desirable.

\section{Salt Use}

A brief telephone survey yielded potential suppliers for $\mathrm{MgCl}$ in solution at a cost as low as $\$ 0.02 / 1 \mathrm{~b}$. However, real salt costs are yet to be established. Only a nominal amount is included for salt replenishment, assuming that the salt will be desalinated and used in fresh water. However, some makeup almost surely will be required. 


\section{Water Usage}

Little consideration was given to: the amounts of water that will be required for pond makeup and cooling towers. This could be a serious: drawback.

\section{Constant Temperature Cycle.}

Assumptions on the use of $25 \%$ of the available solar insolation are probably optimistic. To use the solar insolation as it is available or to maintain a constant pond temperature might be quite difficult in a realistic utility situation.

Energy Removal. When Power Plant Is Not Working.

A: concept has not evolved for the protection of the pond when the power plant is shut"down.: Any power plant will be jdle during some periods. Söme provision must be made to prevent excessive heating of the pond with subsequent loss: of stability when the power plant is down.

\section{Loss of Stability}

Many things could lead to a complete loss of stability. This could put the pond out of commission for months and require millions of dollars for rejuvenation. Such numbers are not included. 


\subsection{ENVIRONMENTAL EFFECTS}

Potential adverse environmental effects from solar ponds include:

- salt disposal effects on land or water;

- salt effects on the atmosphere, such as those encountered near a sea coast;

- possible.leakage of millions of gallons of salt water; and

- possible decommissioning effects of large volumes of salt, gelled water, plastic sheet, etc.

The land area required for solar systems is often regarded as excessive. In fact the land area required for a solar system is probably not any greater than that required for other energy systems when all factors such as mines, etc. required for conventional systems are included. 


\subsection{POSSIBLE IMPROVEMENTS}

While gels seem expensive, there is a possibility that layers of gel or a nonconvecting salt system wi.th small amounts of gel could be used to improve stability.

\section{Reduced Depth of Nonconvecting Layer}

The depth of the nonconvecting layer, in either a salt or a gelled pond can greatly affect the cost. If a layer $1 \mathrm{ft}$ thick were adequate, the cost of the membrane pond would drop by a factor of three. Some insulating value would be lost, but an economic balance between salt cost and heat loss could probably be reached to advantage if a thinner layer were practical.

\section{Increased Depth of Convecting Layer}

In the membrane pond with pressure balanced on each side of the membrane, or in the gelled pond with little weight difference between the convecting and nonconvecting layers, depth of the convecting layer can probably be significantly increased at little cost. This could greatly increase the storage capability and hence the value of the pond.

\section{Pond Heat Exchangers}

Our analysis utilized water extraction from the pond, passing it through heat exchangers to extract the heat. The utilization of heat exchangers in the pond bottom has been considered for nonconvecting ponds. This is probably not practical because of the low conductivity of the water. However, in gelled ponds or membrane ponds with a fresh-water bottom layer, the use of an in-pond heat exchanger may be practical.

\section{Circular Systcms}

The application of circular irrigation technology to pond heat extraction and regeneration may be a useful concept. The use of wet cooling towers appears undesirable because of the low Carnot efficiency; a great deal of heat must be rejected. The use of cooling ponds or some natural feature for heat rejection may improve plant economics. 


\section{Alternate Energy Usage}

The use of solar ponds for heat pump application, industrial bottoming, and power system preheating may be more useful.

First-step feedwater or process heating is a potential application for solar ponds. In an area where the insolation averages $2.3 \mathrm{MW}-\mathrm{hr} / \mathrm{m}^{2}$ (corresponding to $550 \mathrm{ly} /$ day average insolation), a pond with a collection efficiency of 0.3 could deliver $0.7 \mathrm{MW}-\mathrm{hr}$ of $80-90^{\circ} \mathrm{C}$ thermal energy $/ \mathrm{m}^{2} / \mathrm{yr}$.

: A solar pond which can deliver $90^{\circ} \mathrm{C}$ thermal energy can be used in conjunction with a heat pump to deliver economical heating for comfort or process applications. For example, a heat pump with a coefficient of performance of 1.8 (half the thermodynamically-limited maximum possible) would deliver $2.8 \mathrm{~kW}-\mathrm{hr}$ of $227^{\circ} \mathrm{C}$ heating for each $\mathrm{kW}-\mathrm{hr}$ of electrical power supplied to the heat pump; $1.8 \mathrm{~kW}-\mathrm{hr}$ from the pond in addition to the $1 \mathrm{~kW}-\mathrm{hr}$ supplied. To raise $50^{\circ} \mathrm{C}$ thermal energy to $60^{\circ} \mathrm{C}$ thermal energy suitable for comfort heating applications would require an input of $1 / 16 \mathrm{~kW}-\mathrm{hr}$ per $\mathrm{kW}-\mathrm{hr}$ of heating delivered, again with a heat pump half as efficient as is theoretically possible.

\section{Gelled Salt Ponds}

A combination of gelling agent and salt is another possibility; the salt to provide the desired density gradient and the gelling agent to provide viscosity. Also the production of gelling agents in very large quantities might result in very large cost reductions. 


\subsection{CONCLUSIONS}

With respect to the specific objectives of this study, no: unique concepts other than the salt, membrane, and gelled pond concepts were found. There appear to be agricultural applications for convecting ponds. For example, in Japan ponds are used to preheat cold water before it is used for irrigation. (46) A knowledge of solar ponds could probably be applied to such applications in the U.S.

The analysis of performance of the various concepts did not identify any clear.superiority. The state of the art is such that with either nonconvecting salt ponds or gelled ponds additional basic information is required before reasonable engineering decisions can be made. However, the potential additional stability of the membrane and gelled ponds could make them more attractive. The relatively well-established technology of the shallow convecting pond offers a considerable advantage in the near term.

As for costs of the different concepts, an economic advantage is not clear for any specific concept. However, if salt is not free, the membrane pond appears to have a significant potential advantage in that salt may not be required in the convecting region.

A conclusion from this study is that there is a possibility that solar ponds can be inexpensive energy producers. A solar pond can be constructed at a minimum cost of $\$ 1.50 / \mathrm{ft}$ (and up)--less if salt is low cost. This is cheaper than some solar collectors. Basically, water is used for a transparent insulator; it is probably one of the best transparent insulators in existence. In addition, a solar pond has some built-in storage. This is significant for power plant operation primarily for storage of a few hours or a few days. However, it can be significant for longer term storage in low-temperature thermal applications.

It is unlikely that solar ponds will be competitive electrical energy producers in the foreseeable future, except possibly in isolated locations with unique climatic and geological characteristics.

There are significant problems with solar pond operation, particularly large ponds such as might be used for a $10 \mathrm{MW}_{e}$ power plant. There do not 
seem to be readily available answers to all of these problems. However, the nature of the answers which will evolve from an R\&D program cannot be stated positively today. 


\subsection{ACKNOWLEDGEMENTS}

Many persons contributed to this effort on very short notice, including

Ross Gordon, R. H. Moore, R. A. Walter and P. L. Forrest. 


\subsection{REFERENCES}

1. C. H. Bloomster, et al., "GEOCOST: A Computer Program for Geothermal Cost Analysis," Battelle-Northwest, BNWL-1888, 1975.

2. H. Tabor, "Solar Ponds," Electronics and Power 296, 1964.

3. A. Rabl and C. E. Nielsen, "Solar Ponds for Space Heating," Dept, of Physics, Ohio St. Univ., private communication, 1974.

4. L. H. Shaffer, private communication, 1975.

5. A. F. Clark, J. A. Day, W. C. Dickinson and L. F. Wouters, "The Shallow Pond Conversion System: An Analysis of a Conceptual $10 \mathrm{MW}_{\mathrm{e}}$ Plant," UCRC-51533, Lawrence Livermore Laboratory, 1974.

6. R. Bloch, reported by Tabor in Electronics and Power 296, 1964.

7. D. L. Styris, R. Zaworski and 0. K. Harling, "The Nonconvecting Solar Pond, An Overview of Technological Status and Possible Pond Applications," BNWL-1891, Battelle-Northwest, 1975.

8. A. Defant, Physical Oceanography 1:53, 1961.

9. H. Weinberger, "The Physics of Solar Ponds," Solar Energy 8:45, 1964.

10. H. Tabor and R. Matz, Solar Energy 9:177, 1965.

11. C. E. Nielsen, private communication, 1975.

12. D. L. Styris, 0. K. Harling, R. Zaworski and J. Leshuck, "The Nonconvecting Solar Pond - Some Applications and Stability Problems Areas," ISES International Solar Energy Congress and Exposition, U. of California, Los Angeles, CA, 1975.

13. G. Veronis, Journal of Mar. Res., 23:1, 1964.

14. G. Veronis, J. Fluid Mech., 34:315, 1968.

15. V. N. Eliseev, Yu. U. Usmanov and L. N. Teslenko, Appl. Sol. En., 7:17, 1971 .

16. J. S. Turner, J. Fluid Mech., 33:183, 1968.

17. T. G. L. Shiftcliff, Nature, p. 489, 1967.

18. J. S. Turner and H. Stomme1, Geophysics, 52:49, 1964.

19. R. S. Schechter, I. Prigogine and J. R. Hamm, Phys. Fluids, 15:379, 1972. 
20. C. C. Tanner, "The Soret Effect," Proc. Faraday Society, 23:75, 1927.

21. M. G. Vel.arde and R. S. Schechter, Chem. Phys. Let., 12:2704, 1971.

22. D. T. J. Hurle and E. Jakeman, Phys. F1., 12:2704, 1969.

23. H. Tabor, "Large Area Solar Collectors for Power Production," Solar Energy, 7:189, 1963.

24. A. Delyannis and E. Piperoglou, "The Patmos Solar Distillation Plant," Solar Energy, 12:113, 1968.

25. T. A. Lawand, Solar Energy, 12:509, 1969.

26. W. R. Morrison, R. A. Dodge, J. Merriman and L. M. Ellsperman, Selected Water Resources Abs., 1971.

27. W. B. Benton, W. J. Wall and S. R. McKeever, Proc. Am. Soc. Civil Eng., J. Power Div. 96:109, 1970.

28. B. J. S. Barnard and R. Northridge; J. Mech. Eng. Sci. 12:60, 1970

29. C. Elata and 0. Levin, "Hydraulics of the Solar Pond," Presented to the Eleventh Congress of the International Association for Hydraulic Research, Leningrad, 1965.

30. D. G. Daniels, private communication with M. Merriam, 1974.

31. W. R. Debler, J. Eng. Mechanics Div., Proc. ASCE, p. 51, 1959.

32. H. S. Carslaw and J. C. Jaeger, "Conduction of Heat in Solids," (Oxford Univ. Press), .2nd ed., 1959.

33. Yu. Usmanov, V. El iseev and G. Ya. Umarov, Appl. Sol. En., 9:71, 1973.

34. J. Hirschmann, Report on U.N. Conference on New Sources of Energy, New York, p. 478, 1962a.

35. J. Hirschmann, Report on U.N. Conference on New Sources of Energy, New York, p. 499, 1962b.

36. G. Claude, Mech. Eng., 52:1039, 1930.

37. J. W. Bloemer, J. A. Eibling, J. R. Irwin and G. 0. G. Lof, Solar Energy, 9: 197, 1965.

38. Soviet Geothermal Electric Power Engineering ARPA Order \#1622-3, December 1972. 
39. 0. E. Kirchner, Resources Conservation Company, Seattle, WA, personal communication.

40. W. C. Dickinson and R. D. Neifert, "Parameteric Performance and Cost Analysis of the Proposed SOIHO Solar Process Heat Facility," UCRL-51783, Lawrence Livermore Laboratory, 1975.

41. R. H. Douglass, Jr., "Ocean Thermal Energy: An Engineering Evaluation," Proceedings of the Offshore Technology Conference, Houston, TX, Paper OTC 2252, March 5-8, 1975.

42. R. A. Walter, et al., Thermodynamic Modeling of Geothermal Power Plants, BNWL-1911, Battelle-Northwest, Richland, WA, May 1975.

43. General Electric Turbine Manufacturer's Representative, personal communication.

44. Geothermal Energy, Kruger and 0tt, eds., Stanford University Press, Stanford, CA, 1973.

45. Managing Waste Heat With the Water Cooling Tower, Marley Company, 1970.

46. Tetsuo Noguchi, Recent Developments in Solar Energy Research and Application in Japan, Solar Energy, Vol. 15. 


\section{DISTRIBUTION}

OFFSITE

ERDA Division of Solar Energy

Washington, DC 20545

George Kaplan (20)

ERDA Technical Information Center

ERDA Richland Operations Office

B. J. Melton

Bechtel Corporation

50 Beale Street

P. 0. Box 3965

San Francisco, CA 94119

Ernest Y. Lam

Lawrence Livermore Laboratory

P. 0. Box 808

Livermore, CA 94551

W. C. Dickinson

Argonne National Laboratory

9700 S. Cass Avenue

Argonne, IL 60439

Ari Rabl

Washington Public Power Supply System

3000 George Washington Way

Richland, WA 99352

W. C. Wolkenhauer

Ohio State University

Columbus, $\mathrm{OH} 43201$

C. E. Nielsen

Lloyd H. Shaffer, Ph.D.

Consulting Chemist

156 Intervale Road

Stamford, CT 06905
Oregon State University

Department of Mechanicâ 1 and Metallurgical Engineering

Corvallis, OR 97331

R. G. Zaworski

ONSITE

Technical Information Files

(3)

Technical Publications

(1)

Battelle-Northwest

TD Chikalla

TF Demmitt

JG DeSteese

$K$ Drumheller (20)

JB Duffy

LE Erickson

J Goodnight (HARC)

WE Gurwell

OK Harling (20)

EW Kleckner

CA Knutsen

$\mathrm{N}$ Laegreid

$N$ Laulainen

MA McKinnon

PL Peterson

Su Phillips

LC Schmid

DW Shannon

DL Styris

JW Upton

RL Watts

KR Wheeler

RK Woodruff

Economics Library (3) 
